\title{
INEEL Cultural Resource Management Program Annual Report - 2004
}

Julie Braun

Hollie Gilbert

Terri Ireland

Dino Lowrey

Clayton Marler

Brenda Ringe Pace

January 2005

Idaho National Engineering and Environmental Laboratory Bechtel BWXT Idaho, LLC 


\title{
INEEL Cultural Resource Management Program Annual Report - 2004
}

\author{
Julie Braun \\ Hollie Gilbert \\ Terri Ireland \\ Dino Lowrey \\ Clayton Marler \\ Brenda Ringe Pace \\ January 2005
}

Idaho National Engineering and Environmental Laboratory

Idaho Falls, Idaho 83415

Prepared for the

U.S. Department of Energy

Under DOE Idaho Operations Office

Contract DE-AC07-99ID13727 


\section{ABSTRACT}

As a federal agency, the U.S. Department of Energy has been directed by Congress, the U.S. president, and the American public to provide leadership in the preservation of prehistoric, historic, and other cultural resources on the lands it administers. This mandate to preserve cultural resources in a spirit of stewardship for the future is outlined in various federal preservation laws, regulations, and guidelines such as the National Historic Preservation Act, the Archaeological Resources Protection Act, and the National Environmental Policy Act.

The Idaho National Engineering and Environmental Laboratory Site is located in southeastern Idaho, and is home to vast numbers and a wide variety of important cultural resources representing at least 13,000-year span of human occupation in the region. These resources are nonrenewable, bear valuable physical and intangible legacies, and yield important information about the past, present, and perhaps the future. There are special challenges associated with balancing the preservation of these resources with the management and ongoing operation of an active scientific laboratory, while also cleaning up the waste left by past programs and processes. The Department of Energy Idaho Operations Office has administrative responsibility for most of the Site, excluding lands and resources managed by the Naval Reactors Facility and (in 2004) Argonne National Laboratory-West. The Department of Energy is committed to a cultural resource program that accepts these challenges in a manner reflecting both the spirit and intent of the legislative requirements.

This annual report is an overview of Cultural Resource Management Program activities conducted during Fiscal Year 2004 and is intended to be both informative to external stakeholders and to serve as a planning tool for future cultural resource management work to be conducted on the Site.

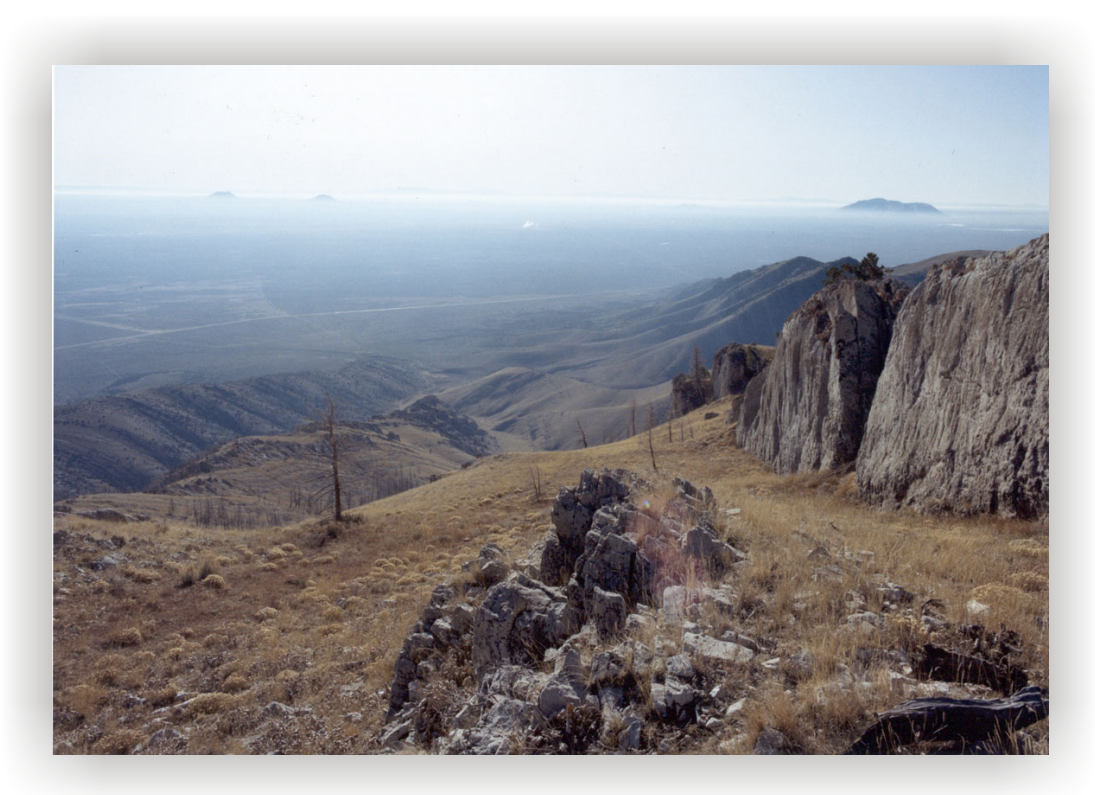




\section{CONTENTS}

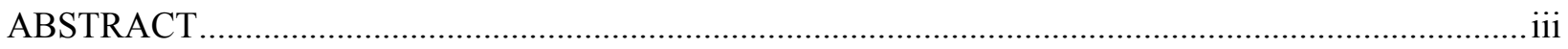

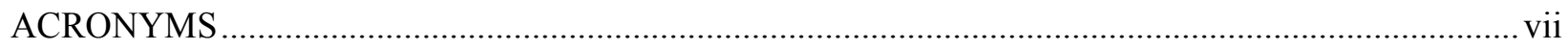

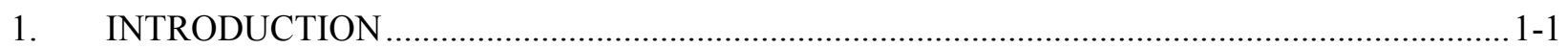

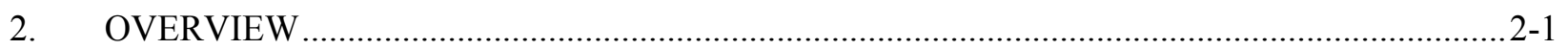

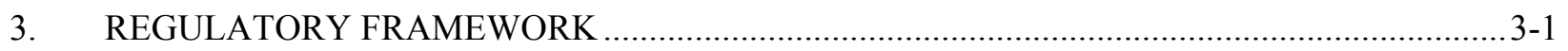

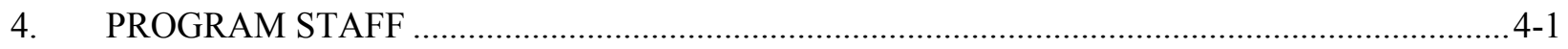

4.1 Tribal and DOE Program Coordinators............................................................... $4-1$

4.2 Cultural Resource Management Office Personnel ...................................................... 4-1

5. CULTURAL RESOURCE MANAGEMENT OFFICE ACTIVITIES......................................5-1

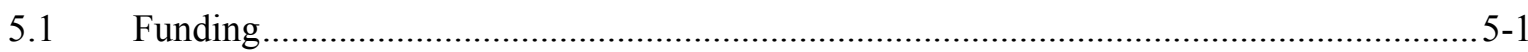

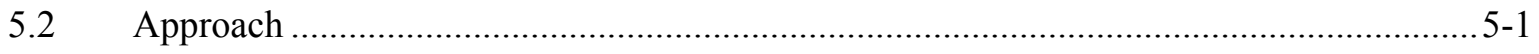

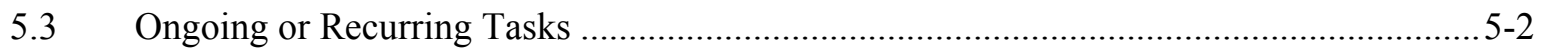

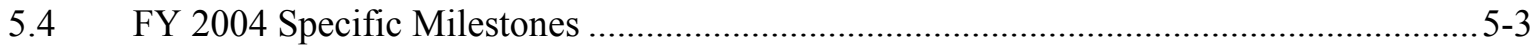

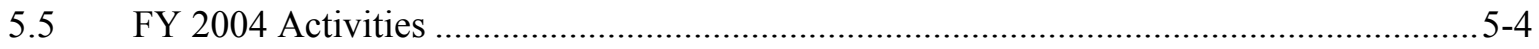

5.5.1 Cultural Resource Management Plan and Programmatic Agreement .............. 5-4

5.5.2 Data Management Systems …....................................................................... 5-4

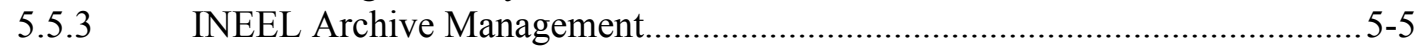

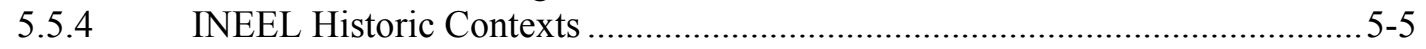

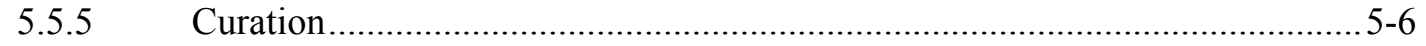

5.5.6 Regulatory and Requirements Reviews .................................................... 5-6

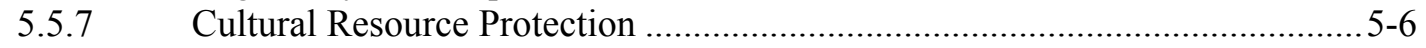

6. STAKEHOLDER AND PUBLIC OUTREACH............................................................... $6-1$

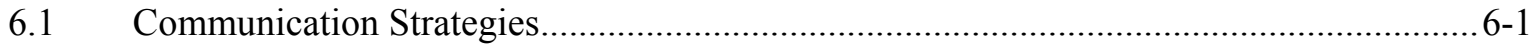

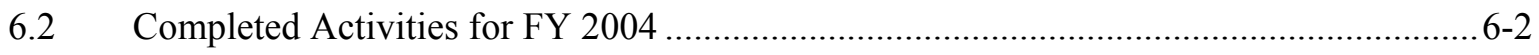

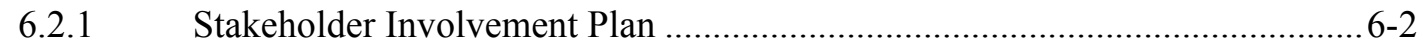

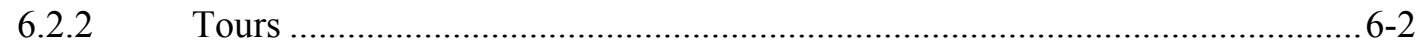

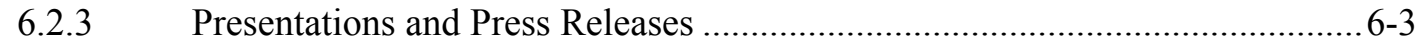

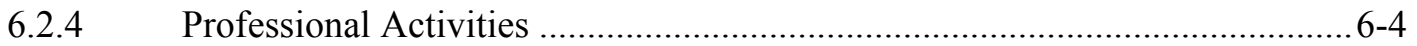

6.2.5 Preservation Partnerships ........................................................................ 6-5

7. NATIVE AMERICAN PARTICIPATION …..........................................................................

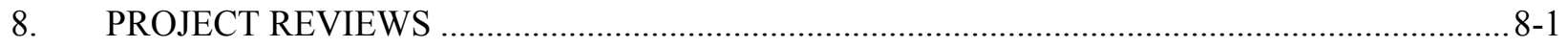


8.1 NHPA Section 106 Project Reviews (Historic Architectural)........................................ 8-1

8.2 NHPA Section 106 Project Reviews (Nonarchitectural) ............................................ 8-8

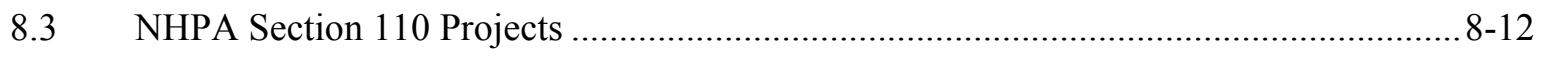

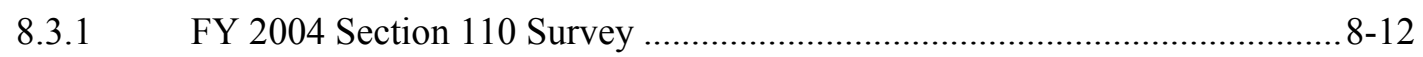

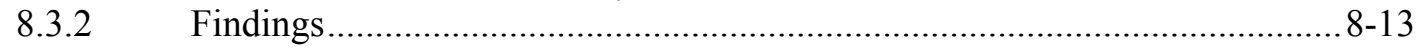

9. SITE AND PROJECT MONITORING …....................................................................... 9-1

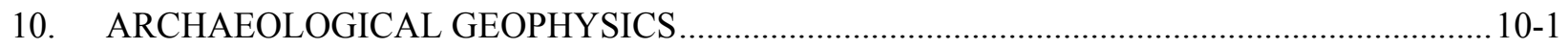

11. PRESENT AND FUTURE ACTIVITIES .......................................................................... 11-1

11.1 FY 2005 (Activities Currently Underway) ................................................................. 11-1

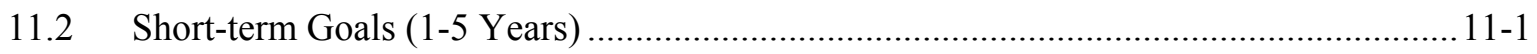

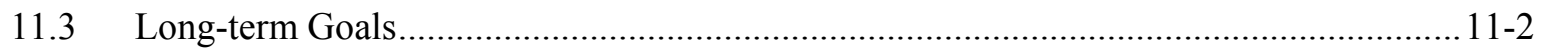

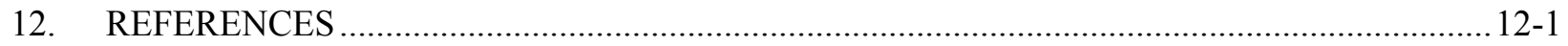

Appendix A-Building and Structures Inventoried in FY 2004 ....................................................

\section{FIGURES}

1-1. Shaded Relief Map of the Idaho National Engineering and Environmental Laboratory Site ......... 1-2

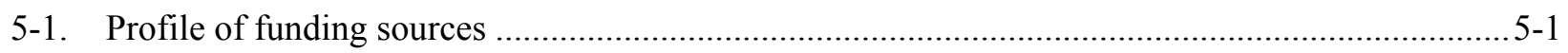

\section{TABLES}

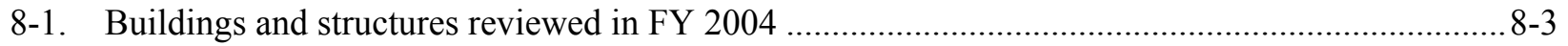

8-2. Nonarchitectural projects reviewed in FY 2004 ...................................................................... 8-9

NOTE: Cover photograph shows East Butte as seen from Middle Butte. 


\section{ACRONYMS}

ACHP Advisory Council on Historic Preservation

AEC U.S. Atomic Energy Commission

AFPA American Folklife Preservation Act

AIRFA The American Indian Religious Freedom Act

ANPG Arco Naval Proving Ground

ARA Auxiliary Reactor Area

ARPA Archaeological Resource Protection Act

BLM Bureau of Land Management

CFA Central Facilities Area

CITRC Critical Infrastructure Test Range Office

CRM Cultural Resource Management

CRMP Cultural Resource Management Plan

CRMO Cultural Resource Management Office

CRWG Cultural Resources Working Group

DOE U.S. Department of Energy

DOE Idaho U.S. Department of Energy Idaho Operations Office

FTE full-time employee

FY fiscal year

GLO General Land Office

HAER Historic American Engineering Record

HeTO Shoshone-Bannock Heritage Tribal Office

ICP Idaho Completion Project

IMNH Idaho Museum of Natural History

INEEL Idaho National Engineering and Environmental Laboratory

INL Idaho National Laboratory

INTEC Idaho Nuclear Technology and Engineering Center

ISU Idaho State University 


$\begin{array}{ll}\text { MDA } & \text { Mass Detonation Area } \\ \text { MOA } & \text { memorandum of agreement } \\ \text { NEPA } & \text { National Environmental Policy Act } \\ \text { NPHA } & \text { National Historic Preservation Act } \\ \text { NRF } & \text { Naval Reactors Facility } \\ \text { NRTS } & \text { National Reactor Testing Station } \\ \text { PBF } & \text { Power Burst Facility } \\ \text { PL } & \text { Public Law } \\ \text { RWMC } & \text { Radioactive Waste Management Complex } \\ \text { SHPO } & \text { State Historic Preservation Office } \\ \text { STF } & \text { Security Training Facility } \\ \text { TAN } & \text { Test Area North } \\ \text { TRA } & \text { Test Reactor Area } \\ \text { USC } & \text { United States Code } \\ \text { USGS } & \text { U.S. Geological Survey } \\ \text { WRRTF } & \text { Water Reactor Research Test Facility } \\ \text { WWII } & \text { World War II }\end{array}$




\section{INEEL Cultural Resource Management Program Annual Report - 2004}

\section{INTRODUCTION}

The Idaho National Engineering and Environmental Laboratory (INEEL) Site is an 890 square mile expanse of land, (see Figure 1-1) most of which has been withdrawn from public use since the early 1940 s, and is presently managed by the U.S. Department of Energy Idaho Operations Office (DOE Idaho). It is located on the northern margins of the Eastern Snake River Plain, tucked against the foothills of the Beaverhead, Lemhi, and Lost River Ranges. Most atmospheric moisture tends to precipitate in the mountains adjacent to the INEEL Site resulting in an average annual precipitation of only $22 \mathrm{~cm}(8.7 \mathrm{in}$.) on the Site while the adjacent mountains and valleys enjoy an average of around 10-15 in./yr (Orr and Orr 1996). Despite the relative paucity of atmospheric moisture, the Site itself is relatively well watered; or at least was during prehistoric times, as a result of its proximity to the mountains and valleys and the streams that drain from this region. For the most part the Site landscape reflects the broader geologic context of the Snake River Plain through the dominance of lava fields variably blanketed with aeolian loess deposits.

Although volcanic flows and associated features such as Big Southern, Middle, East, Antelope, and Circular Buttes tend to dominate a deceptively flat landscape, much of the Site is located in the Big Lost River Trough, also known as the Pioneer Basin. The Big Lost River Trough is defined as a closed topographic depression, hydrologically fed by drainage systems that extend between Big Southern, Middle, and East Buttes to the south, and Mud Lake, the Little Lost River, Big Lost River, and Birch Creek Sinks to the north (Butler 1968). The central feature of the trough is the Big Lost River itself, which enters the Site from the west, flowing southeasterly for

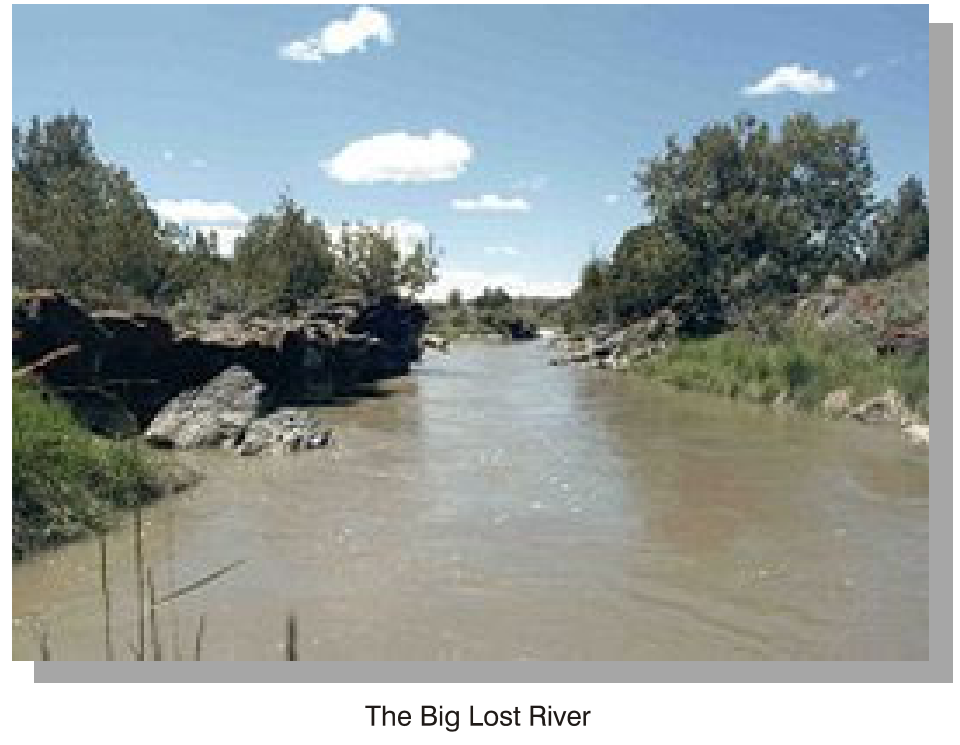
about 6 miles before abruptly turning to the northeast and finally to the north, winding through a broad alluvial plain interspersed with basalt outcrops for 25 miles before a combination of stream flow rates, gradient, and soil porosity cause the river to disappear or "sink" into the Snake River Plain Aquifer. The Big and Little Lost Rivers, Birch Creek, their "sink" areas and numerous scattered playas comprise the major Site surface hydrological features. Throughout history these features, combined with the subsurface aquifer have been defining factors in human land-use choices. 


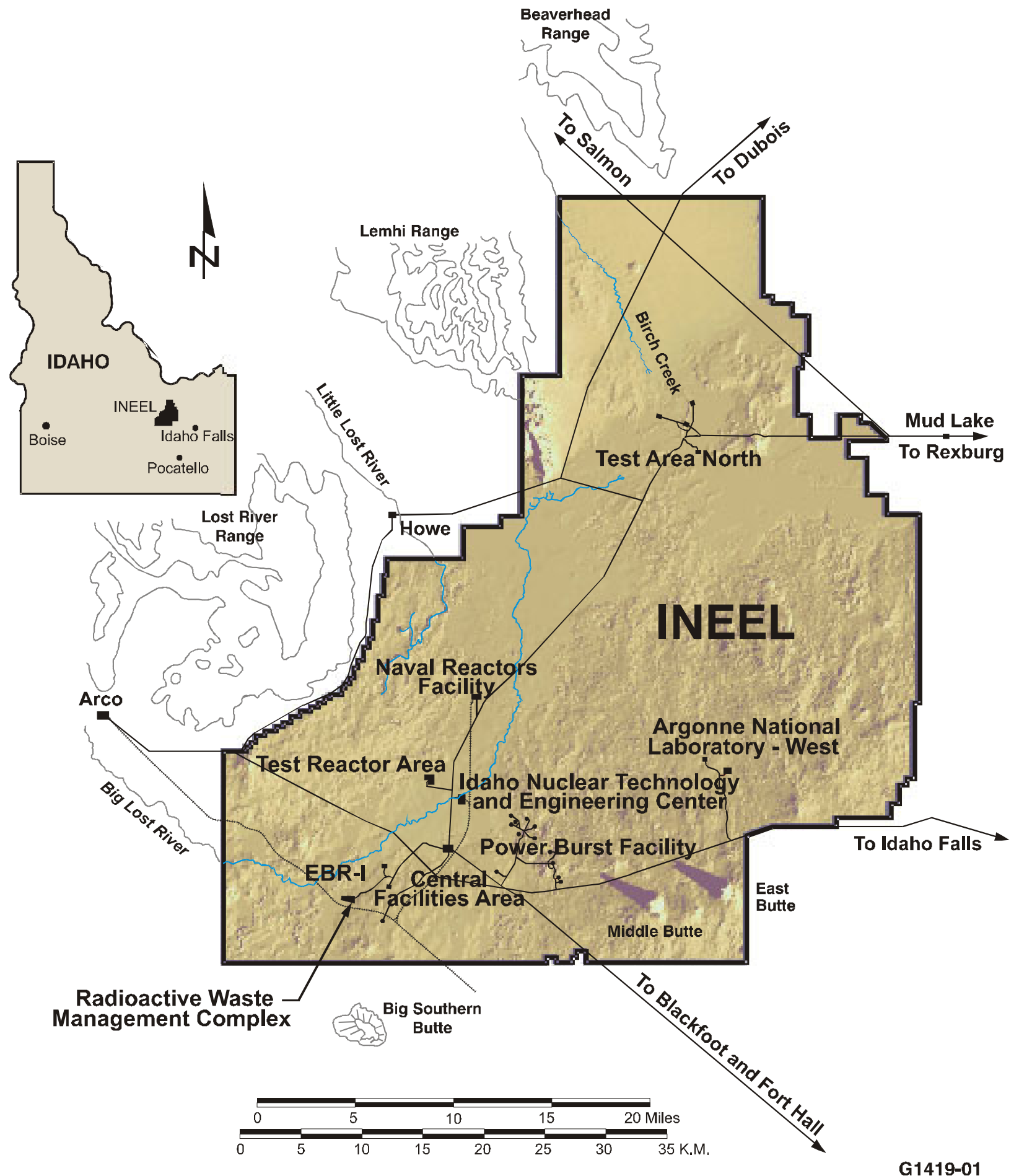

Figure 1-1. Shaded Relief Map of the Idaho National Engineering and Environmental Laboratory Site. 


\section{OVERVIEW}

The INEEL Site landscape provides the stage on which at least 13,000 years of human history has transpired in an intimate relationship with the natural environment. The abundant and varied tangible evidence of this history comprises one aspect of Site cultural resources that DOE Idaho and its contractors are charged with protecting.

Evidence of early Native American land use is ubiquitous, though not randomly distributed on the landscape. To date, roughly $8.6 \%$ of the Site has been systematically inventoried, yielding nearly 2,200 recorded archaeological sites. Predictive models developed to facilitate long-term project planning and ongoing protection of this fragile legacy (Ringe 1995; Plager et al. 2004) have provided estimates of as many as 75,000 additional locations within the INEEL Site boundaries.

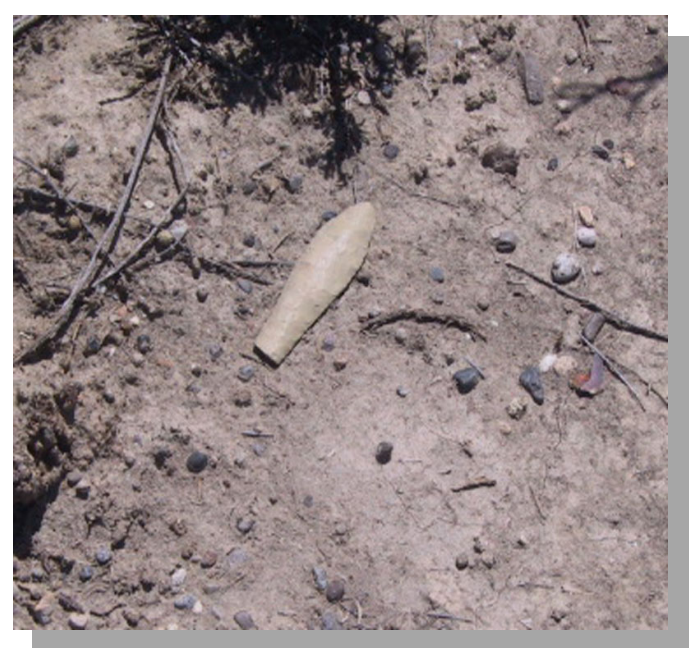

An approximately 10,000 Year-old "Haskett" Spear Point

Since the early 1800 s, Euro-American presence has been felt on what is now the INEEL Site. Initially, land use was light and transient, perhaps much like that of the early Native American occupants. Like those earlier people, the first Euro-American occupants were intent on resource extraction. However, unlike the earlier inhabitants whose focus was on food to sustain life, they were intent on the extraction of beaver pelts for monetary purposes. In

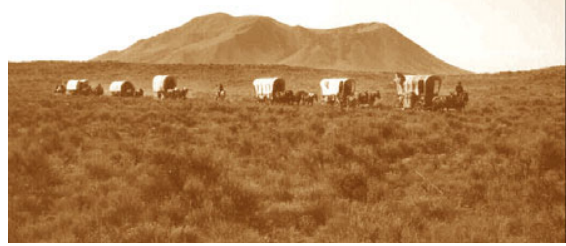

Goodale's Cutoff Crossing Re-enactment 1852 Goodale's Cutoff was established as a northern extension of the Oregon Trail; an alternate route to reach the rich resources of the Oregon Territory. Still, this was transient activity, and the human imprint on the landscape remained modest.

Between 1860 and 1880, Goodale's Cutoff came to be used to trail cattle and eventually sheep, from western ranges in Oregon, Washington, and Idaho to eastern markets. During this same time period the mining industry in the mountains of Central Idaho boomed and a number of wagon and stage roads between growing towns and cities along the Snake River and the mining camps of the interior were established. Many of these roads crossed the Site and, in fact, are still in use today. By the early 1880s, a number of ranching operations were underway at the north end of the Site near Howe and around the Big Lost, Little Lost, and Birch Creek Sinks. Cattle were routinely herded across the Site from these areas to summer range near Big Southern Butte (DOE-ID 2004; Gerard 1982).

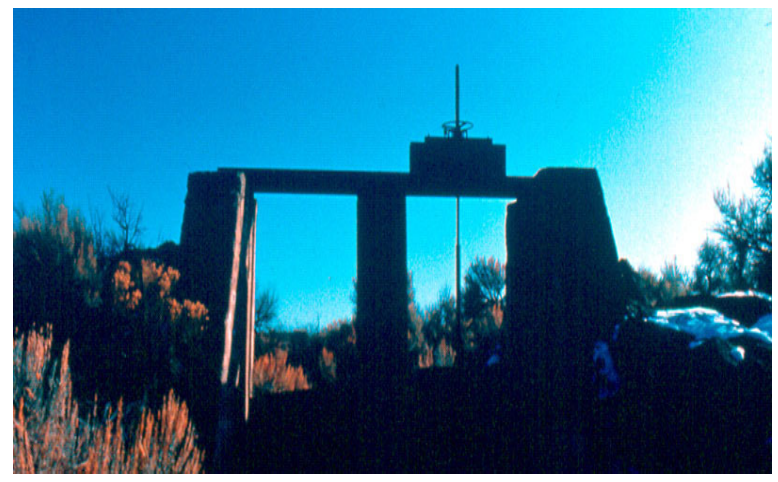

Big Lost River Diversion Canal Headgates 
While Euro-American settlement began near the Site as early as 1855, it wasn't until passage of the Carey Land Act in 1894, and particularly the Desert Reclamation Act in 1902, that homesteading efforts on the Site began in earnest. Most of these homesteads were located along the Big Lost River. Between 1905 and 1920 a number of water-control projects including the Mackay Dam and numerous irrigation canal systems were established on the Big Lost River. On the Site, the town of Pioneer was established adjacent to the Oregon Shortline railroad and the Big Lost River near what is now the Radioactive Waste

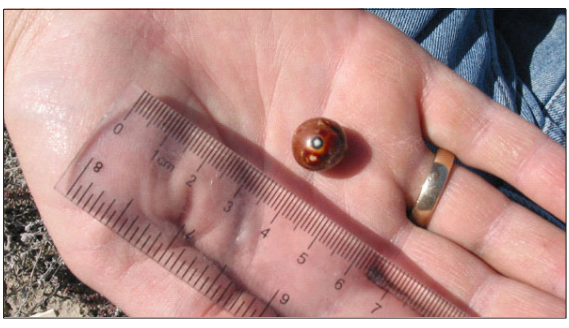

Clay Marble from an Early 20th Century Homestead Site Management Complex (RWMC) in the southwest corner of the Site. Extensive irrigation canal and ditch systems extend and radiate from the Big Lost River near the RWMC all the way to the northern reaches of the Site. Although nearby irrigation projects, such as the Mud Lake Irrigation District, were successful, for a variety of reasons, including soil porosity and upstream water use, irrigation efforts on most of the INEEL area failed and by the mid-1920s it was essentially abandoned. In addition to roads and canal systems, artifacts from the 1800s and early 1900s that are found on the desert today include stagecoach stations and remnants of homesteading activity such as domestic items and children's toys that allow more personal insight into the daily lives of the early pioneers. Approximately 100 historic archaeological sites have been recorded from this period and hundreds more remain to be recorded.

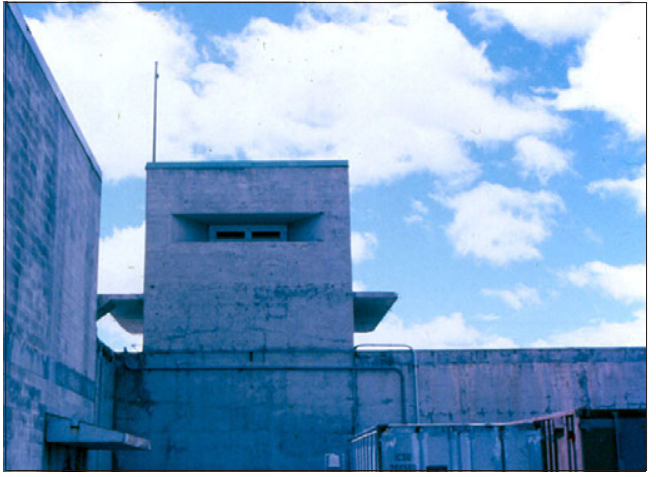

WWII ANPG Range and Fire Control Tower

With the outbreak of World War II (WWII), Pocatello, Idaho was selected as an ideal location to construct an ordnance plant with a mission to reline and test Pacific Fleet naval armament. Shortly after construction of the ordnance plant was completed, the Arco Naval Proving Ground (ANPG) was established on core lands that would eventually become the INEEL Site about 12 miles east of Arco, 50 miles northwest of Pocatello, and a similar distance west of Idaho Falls, as an ideal remote location to test the relined guns. Beginning late in 1942, testing began and during the course of the war, all manner of ship weaponry, from anti-aircraft guns firing 3-in. rounds to the main battleship 16-in. guns were test-fired at the ANPG. The latter fired 2,800-pound test rounds from the Scoville facility (now the Central Facilities Area) as far as 20 miles to the north. After the end of WWII, the ANPG continued its testing mission as an ideal location to test various kinds of conventional explosive ordnance. The tests were designed to explore storage and transport methods to minimize the potential for sympathetic explosions. Artifacts remaining from the WWII period include buildings, structures, unexploded ordnance along with discarded domestic items left behind by ordnance workers and their families.

In 1949, the newly established U.S. Atomic Energy Commission (AEC) selected the ANPG as the location to build and test nuclear reactors. Land transfers between the Department of Defense and the AEC were concluded and the National Reactor Testing Station (NRTS) was established. Later that year, and again in the early 1950s,

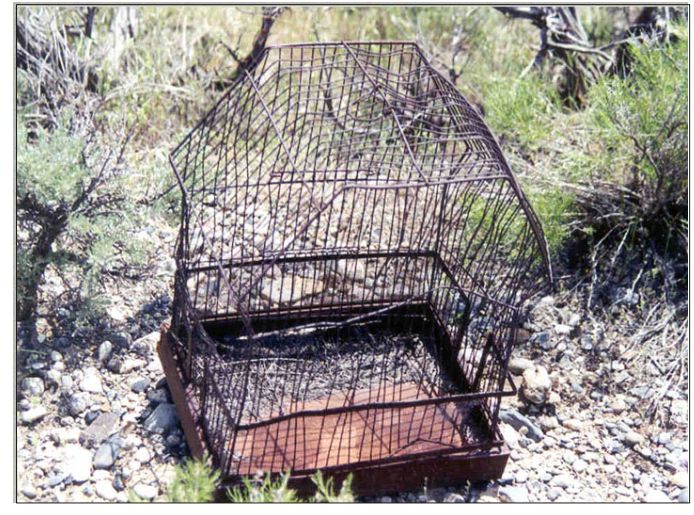

Birdcage found at a WWII Era Dump additional land withdrawals were made to bring the facility close to its current 890 square miles. The purpose of the NRTS was to provide an isolated location where prototype nuclear reactors could be 
designed, built, and tested. The Site was renamed the Idaho National Engineering Laboratory in 1974, and again renamed the Idaho National Engineering and Environmental Laboratory in 1997. In 2005 it will become the Idaho National Laboratory.

Since its establishment, 52 "first-of-a kind" reactors and associated support structures have been constructed at this remote facility. The Laboratory-built environment presently consists of nine active facility areas (see Figure 1-1) separated by variable expanses of undeveloped high desert

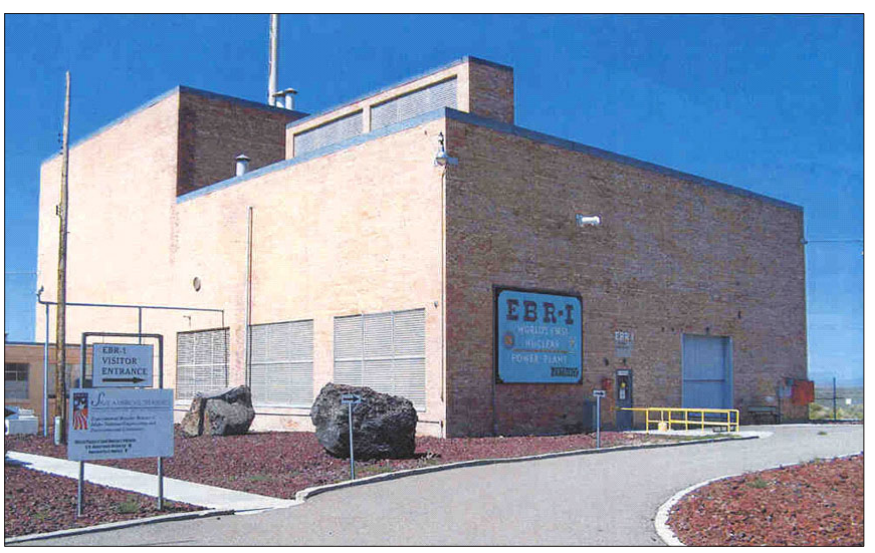

EBR-I, First Nuclear Reactor to Produce Usable Quantities of Electricity but connected by paved and unimproved roads. In recent years, the primary mission has been to monitor and clean up residual discharges, buildings, and structures from WWII activities and the original reactor testing mission as mandated by several laws and legal agreements. Present and future Laboratory missions include the development of the next generation of nuclear reactor technology, the development and testing of national security technologies, and maintaining and expanding its role as a multi-program national laboratory. A 1997 inventory of DOE Idaho buildings identified over 200 that are historic, including EBR-I, a National Historic Landmark. Most are scheduled for demolition as part of the environmental cleanup effort (DOE-ID 2004). Other nuclear era artifacts include the prototype nuclear-powered jet engines, structures, and perhaps most significantly, a massive archive that includes technical reports, engineering drawings and photographs documenting the significant Laboratory history.

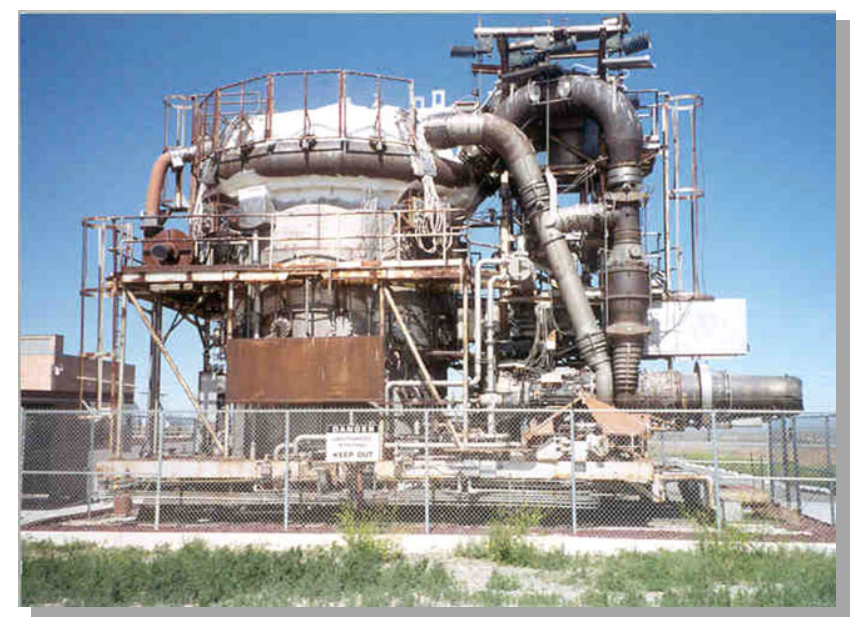

Prototype Nuclear-powered Jet Engine

Tangible evidence of the past such as lithic artifacts, prehistoric campsites, historic trails, homesteads, buildings and structures, and archival documents such as those described above comprise one form of cultural resource. The second form is less easily defined but generally consists of cultural and natural places, landscapes, viewsheds, select natural resources, and sacred areas or objects that have importance for Native Americans and others such as the Oregon and California Trail Association. Ongoing consultation with these groups is

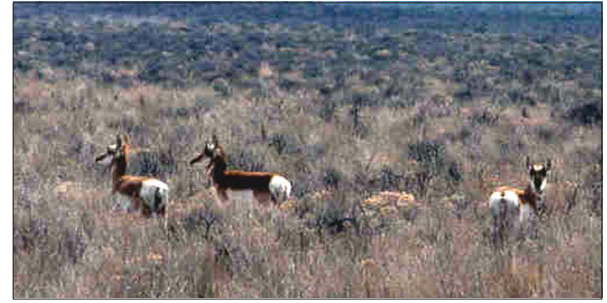

Pronghorn Grazing on Site Sagebrush Steppe facilitating the identification and protection of these less tangible cultural resources. 
2-4 


\section{REGULATORY FRAMEWORK}

A comprehensive annotated list of regulatory and procedural drivers for the management of Site cultural resources is contained in Appendix A of the INEEL Cultural Resource Management Plan (DOE-ID 2004). These requirements are broadly encapsulated in three federal laws; the National Environmental Policy Act of 1969 (NEPA 1969), the Archaeological Resource Protection Act of 1979 (ARPA 1979), and the National Historic Preservation Act of 1966 (NHPA 1966), as amended, and their implementing regulations. NEPA implements the federal environmental protection policy by requiring information gathering, planning, and assessment in advance of projects or actions that occur on federal land, or are federally licensed or funded, and extends protective provisions to important historic, cultural, and natural aspects of our national heritage. The ARPA establishes permit requirements for archaeological work conducted on federal lands, and criminal and civil penalties for the unauthorized excavation, removal, damage, alteration, or defacement of any archaeological resource located on public or Indian lands. This act also prohibits the sale, purchase, exchange, transportation, receipt, or offering of any archaeological resource obtained in violation of any provision of the act. Finally, ARPA fosters increased cooperation and exchange of information between governmental authorities, the professional archaeological community, and private individuals having collections of archaeological resources and data.

The NHPA establishes the National Register of Historic Places and defines historic properties as those that meet National Register of Historic Places criteria and are, therefore, eligible for listing on the National Register. Properties that are eligible for listing are afforded the same protection under the law as those that are listed. NHPA Sections 106 and 110 are particularly important for the identification, management, and protection of the Site's cultural resources. The protective provisions of the NHPA apply only to those resources that are determined to be eligible or potentially eligible for nomination to the National Register of Historic Places. Many Native American sacred sites, traditional cultural areas, and sites or features of local interest are not eligible for listing on the National Register, but nonetheless are cultural resources and are no less important to local tribal members and stakeholders. Other laws such as NEPA, American Indian Religious Freedom Act (AIRFA 1978), and the American Folklife Preservation Act (AFPA 1976) do recognize their importance and DOE Idaho is committed to their protection at the Site. The DOE Cultural Resource Management Policy (DOE P 141) illustrates this commitment.

Executive Order 13287 (2003) states that federal agencies have a responsibility to provide a leadership role in preserving America's heritage. Federal agencies must manage the cultural resources under their jurisdiction as assets to their departments and missions while contributing to the vitality and economic well-being of the nation's communities and fostering a broader appreciation for the development of the United States and its underlying values. This executive order directs federal agencies to maximize efforts to integrate the policies, procedures, and practices of the National Historic Preservation Act. It directs them to promote the preservation of irreplaceable cultural resources by advancing the protection and continued use of their historic properties and pursuing partnerships with state and local governments, Indian tribes, and the private sector. Finally, DOE's commitment to cultural resource management and preservation is outlined in several agency and INEEL-specific policies and agreements. For details see Appendix A of the INEEL Cultural Resource Management Plan (DOE-ID 2004).

The Cultural Resource Management (CRM) office staff has prepared a Cultural Resource Management Plan (DOE-ID 2004) for DOE Idaho as the most efficient means to maintain compliance with regulatory drivers and implement CRM policies and procedures. This plan customizes and streamlines cultural resource compliance activities to balance historic preservation with the need to clean up the environment and allow present and future projects to proceed, while maintaining strong focus on the intent of the regulatory drivers, which is to preserve the significant heritage contained within the Site 
boundaries; in other words, to create a balance between the past, the present, and the future. Compliance processes contained in the management plan have been formalized, legitimized, and implemented through a programmatic agreement between DOE Idaho, the State Historic Preservation Office (SHPO), and the Advisory Council on Historic Preservation (ACHP).

This annual report constitutes an inaugural publication that responds to two fundamental needs. First, a condition of the programmatic agreement is that the CRM Program will regularly report to stakeholders on its activities such that they can be assured that required policies and procedures set forth in the INEEL Cultural Resource Management Plan are adhered to, specific milestones are met, and more generally that DOE Idaho and its contractors maintain a tradition of responsible stewardship. The second need that this report is intended to address refers to a desire for enhanced stakeholder involvement in the planning process. The DOE Idaho and the CRM Program staff embrace the idea that multiple and diverse viewpoints will create a synergistic environment that can only improve the effectiveness of the Site cultural resource stewardship. The intent is that this annual review of past activities be used in tandem with an annual stakeholders meeting that will provide a forum for discussion of past, present, and future goals and priorities for the Cultural Resource Management Program. 


\section{PROGRAM STAFF}

\subsection{Tribal and DOE Program Coordinators}

At the INEEL, DOE Idaho's Environmental Technical Support Division takes responsibility for oversight of the cultural resource management program through a designated cultural resources coordinator, Bob Starck. Bob Pence of the DOE Public Affairs office has lead responsibility for coordinating communications and interactions with the Shoshone-Bannock Tribes, and Willie Preacher is the Shoshone-Bannock Tribal DOE Program manager.

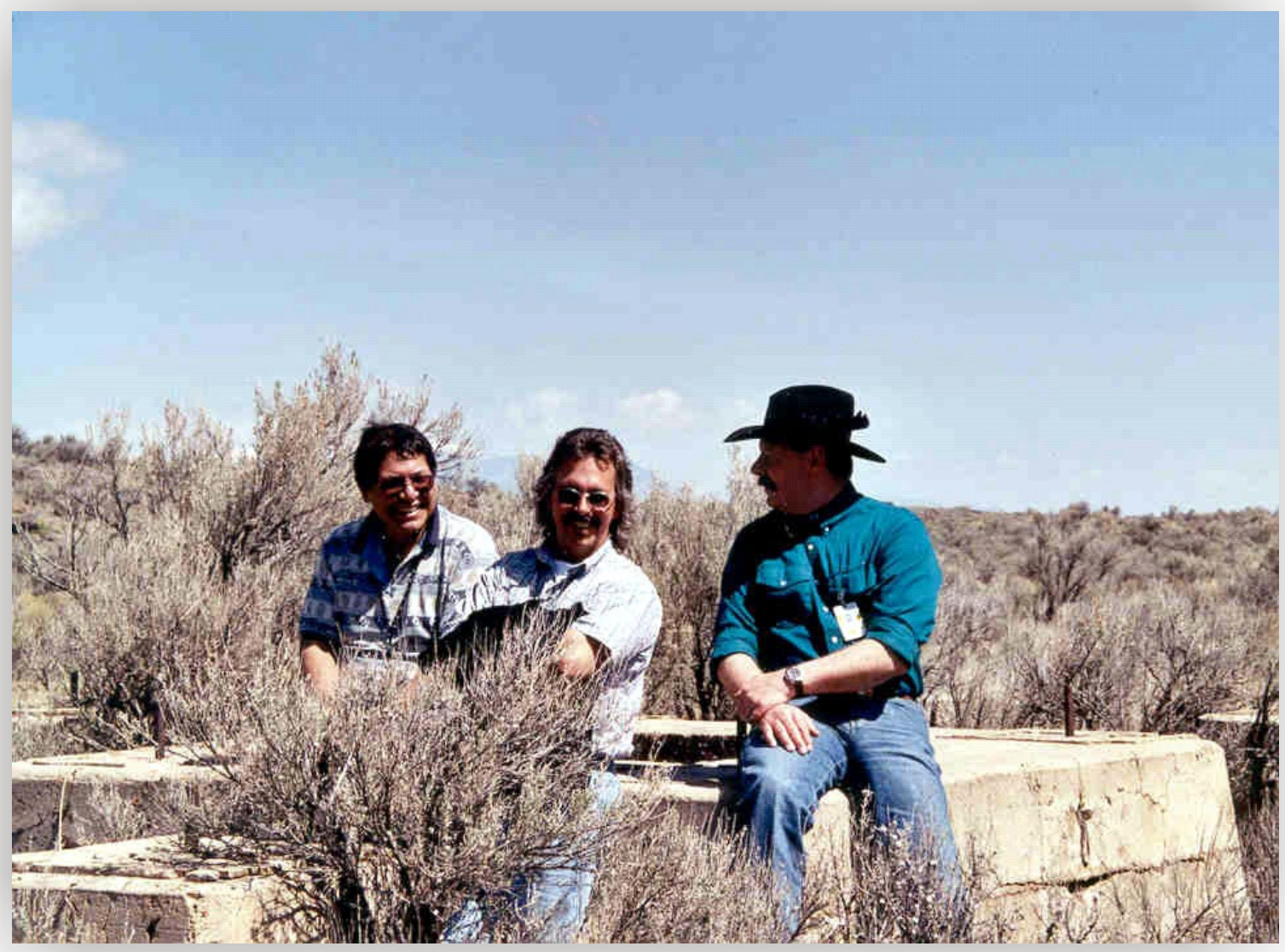

Willie Preacher, Shoshone Bannock Tribes; Bob Starck and Bob Pence, DOE-ID

\subsection{Cultural Resource Management Office Personnel}

DOE Idaho entrusts execution of its cultural resource policies along with regulatory compliance oversight to the INEEL Cultural Resource Management Office (CRMO), whose staff is comprised of prime contractor personnel and includes qualified professionals in the fields of archaeology, history, architectural history, historic preservation, and sociology. The described technical capabilities reflect education and training but not necessarily current job function. Shifting funding levels and sources require adaptability and versatility, and much of the work presently performed by CRMO staff is actually unrelated to cultural resource management (e.g., borrow source management and geological mapping.) 


\section{Cultural Resource Management Office Personnel}

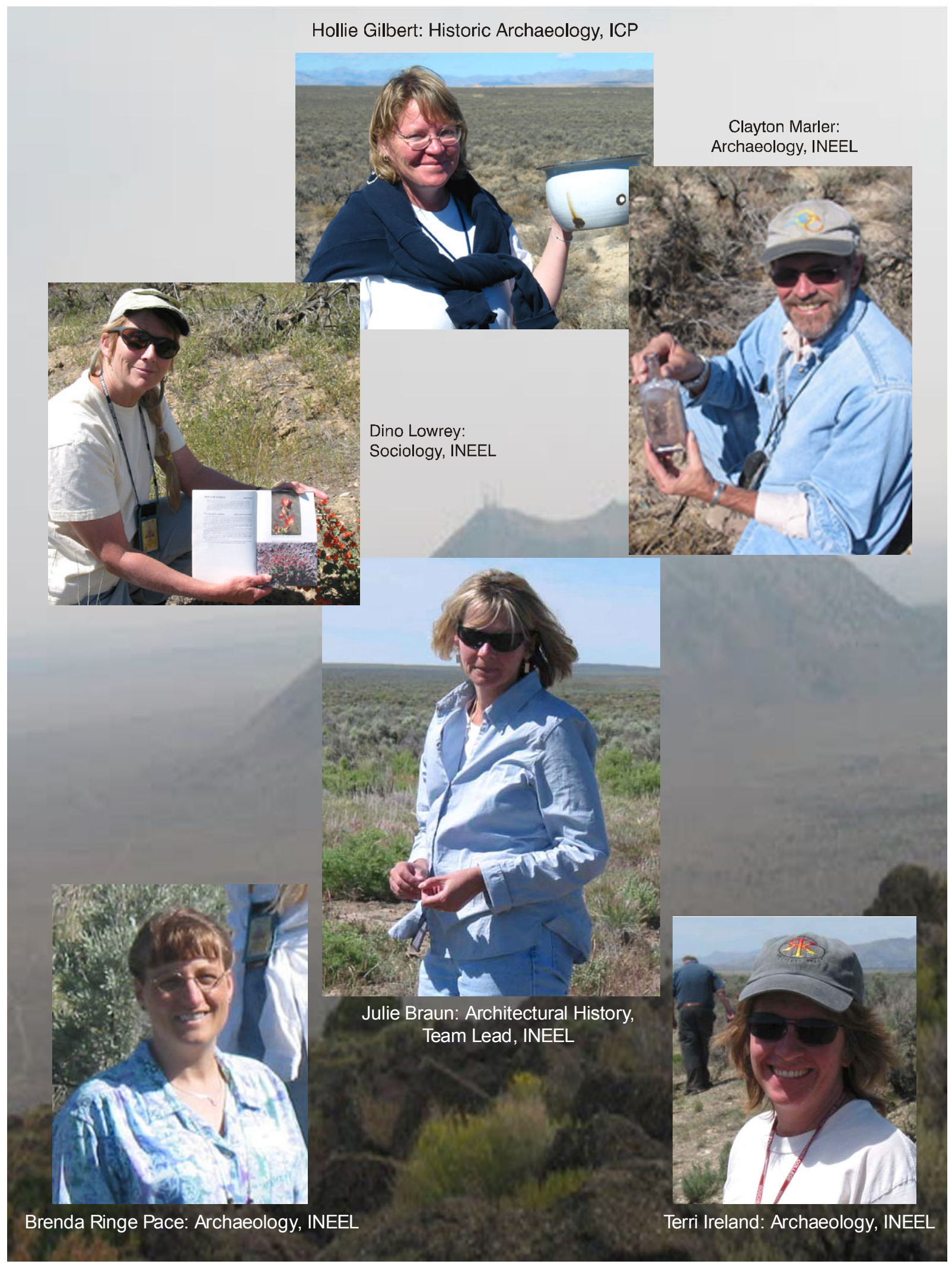




\section{CULTURAL RESOURCE MANAGEMENT OFFICE ACTIVITIES}

\subsection{Funding}

In general, there are two types of funding that support CRM work on the Site. "Direct" funding is provided by specific projects or programs to support compliance with Section 106 of the NHPA, while "Indirect" or overhead funding is provided to accomplish the crosscutting management activities not associated with specific projects and to address the regulatory drivers other than Section 106. In 2004, the DOE let two separate contracts that will fundamentally divide the Site into two distinct entities. The Idaho Completion Project (ICP) was created to focus solely on cleanup operations, while overall facility operations and management coalesced into an organization whose purpose is aligned with current and future research and development missions. (Under the new contractor, as of February 1, 2005, this organization will be called the Idaho National Laboratory [INL].) In 2004, the cleanup operations funded approximately 1.5 full-time employees (FTEs) to support cultural resource milestones associated with accelerated cleanup while the INEEL provided indirect funding for approximately 2.5 FTEs and direct funding for 0.5 FTEs. The remaining funding $(1.5 \mathrm{FTE})$ was for non-CRM related work such as geotechnical graphics and borrow source management. See Figure 5-1 for a profile of funding sources.

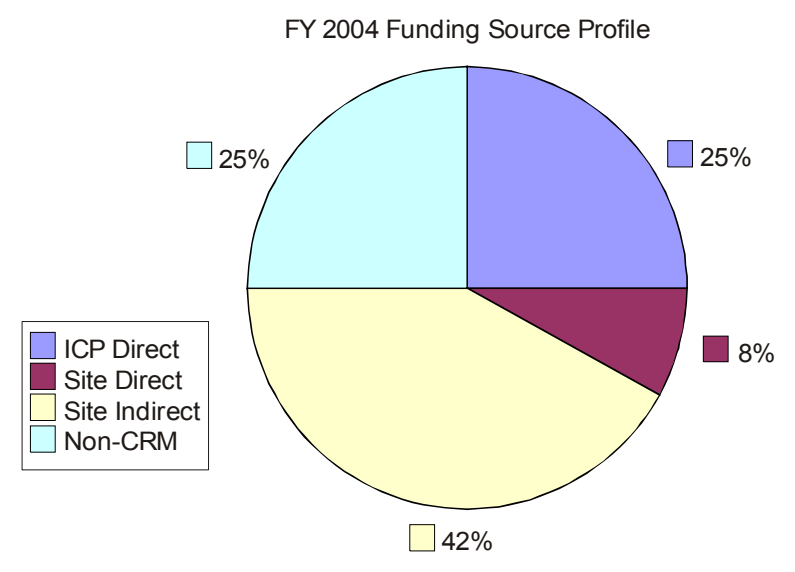

Figure 5-1. Profile of funding sources.

The balance of this report describes accomplishments resulting from ICP direct, Site direct, and Site indirect CRM funding only.

\subsection{Approach}

Cultural resource management on the Site is a dynamic process with some short-term goals and activities being accomplished each year in support of the overarching management goals of identification, evaluation, and resource protection and preservation as described in the INEEL CRM Plan. As specific tasks are accomplished or goals achieved, they might be dropped from the list while others might become "ongoing activities." New goals and tasks are added in response to changing conditions at the Site and within the regulatory framework that drives compliance activities, and in consideration of comments and advice from stakeholders.

The following lists reflect identified opportunities for programmatic improvement, ongoing management responsibilities, and the need for a comprehensive, effective management program. The intent is to provide a program that is not only responsive to the letter of cultural resources law but one that 
addresses the full suite of cultural resources present on the Site in a manner consistent with the spirit of long-term stewardship, stakeholder involvement, and DOE policy.

\subsection{Ongoing or Recurring Tasks}

Ongoing or recurring tasks that will continue to be addressed each year include:

- Implement and update the Cultural Resources Management Plan, as needed

- $\quad$ Complete the annual questionnaire on CRM activities for the Secretary of Interior

- $\quad$ Complete a year-end report for all CRM Office activities (beginning in FY 2005)

- $\quad$ Conduct an annual stakeholders meeting (beginning in FY 2005)

- $\quad$ Continue public outreach and stakeholder involvement

- $\quad$ Seek preservation grant opportunities

- Continue to collect baseline data for cultural chronologies and land-use patterns on the Site

- $\quad$ Continue NHPA Section 110 survey programs to directly support research designs and contexts and to target under-represented regions and property types for survey and inventory

- $\quad$ Continue maintenance and enhancement of electronic data management systems and CRM project archives and files

- Develop site protection plans for historically or culturally important resources or areas

- $\quad$ Form preservation partnerships with local, regional, and national stakeholders

- $\quad$ Coordinate activities with the SHPO, ACHP, Shoshone-Bannock Tribes, and other interested parties

- $\quad$ Ensure the adequacy of contractor policies and procedures regarding compliance with requirements for coordinating work with the Shoshone-Bannock Tribes

- $\quad$ Update historic contexts and research designs

- Conduct appropriate National Register eligibility evaluations and reevaluations

- $\quad$ Oversee and/or conduct all NHPA Section 106 compliance work.

Each year performance measures in the form of specific milestones related to these general activities are selected to guide work activities and gauge programmatic effectiveness. In 2004, the CRMO successfully completed all assigned milestones. 


\subsection{FY 2004 Specific Milestones}

Specific milestones for FY 2004 included the following:

- $\quad$ Update and finalize The Idaho National Engineering and Environmental Laboratory, A Historical Context and Assessment, Narrative and Inventory (INEEL 2003)

- $\quad$ Finalize and implement the INEEL Cultural Resource Management Plan and associated programmatic agreement

- $\quad$ Draft INEEL Archival Plan

- Develop a stakeholder involvement plan

- Initiate inventory of Power Burst Facility (PBF) and Test Area North (TAN) non-building property types

- $\quad$ Complete PBF Special Power Excursion Reactor Tests and TAN Historic American Building Survey and Historic American Engineering Record reports

- $\quad$ Submit INEEL signature facilities list to DOE Idaho

- Develop a provenience tag for post-1942 artifacts

- $\quad$ Identify interim storage for post-1942 artifacts

- $\quad$ Develop a formal cultural resources permitting program

- Develop a functional cultural resource data management system

- $\quad$ Conduct monitoring at selected sites

- $\quad$ Prepare a site protection plan for the CFA facility

- $\quad$ Prepare a final report for monitoring conducted during FY-04

- $\quad$ Organize and participate in a Historic Preservation Month public tour of INEEL Site cultural resources

- Develop a cultural resource protection training program for all INEEL employees

- Work with the Museum of Idaho to update its INEEL exhibit and the exhibits at EBR-I using grants and donations

- Develop an outline for a 10-year CRM Program Implementation Plan that includes cost forecasts

- $\quad$ Conduct NHPA Section 110 archaeological surveys along the Big Lost River channel that extends between Highway 33 and TAN.

The following sections discuss FY 2004 accomplishments as related to both ongoing activities and specific milestones. 


\subsection{FY 2004 Activities}

\subsubsection{Cultural Resource Management Plan and Programmatic Agreement}

Completion of the Idaho National Engineering and Environmental Laboratory Cultural Resource Management Plan (DOE-ID 2004) was one of the more significant accomplishments of FY 2004. While it is understood that this is a dynamic document that will undergo some change each year, SHPO and ACHP review and acceptance provided the basis for development of a Programmatic Agreement with DOE Idaho that allows a measure of autonomy with regard to Site cultural resource management. The CRMP was developed over several years with the assistance and input of the Shoshone-Bannock Tribes, SHPO, ACHP, National Park Service, and others. The CRMP was finalized in August 2004 and is intended to guide the long-term management of Site cultural resources. It guides all INEEL Site preservation and compliance activities, and the Programmatic Agreement between the SHPO, ACHP, and DOE Idaho provides the basis for the CRMP's implementation.

\subsubsection{Data Management Systems}

The INEEL CRM Office maintains extensive archives documenting previous cultural resource investigations on the INEEL. Hard-copy and electronic formats are utilized. A newly developed Data Management Tool (DMT) is improving management and long-term stewardship of this information. The fully integrated system links an archaeological database, a historical database, and a research database to spatial data through a customized user interface using a geographical information system (GIS) and Active Server Pages (ASP). Components of the DMT are tailored specifically to the INEEL and include automated data entry forms for historic and prehistoric archaeological sites, historic architectural resources, specialized queries and reports that address both yearly and project-specific documentation requirements, and unique field recording forms. A predictive modeling component increases the DMT's value for land use planning and long-term stewardship. The DMT enhances the efficiency of archive searches, improving customer service, oversight, and management of the large INEEL cultural resource inventory.

The three DMT databases were developed in Microsoft Access $97^{\mathrm{a}}$ and in FY 2004 were upgraded to Access 2000. Windows operating systems that run the DMT were also upgraded in FY 2004 to Windows Professional 2003 and the server was upgraded to Windows Server 2000. The archaeological predictive modeling component was also upgraded with new information collected through an educational alliance with Idaho State University (Plager et al. 2004). Initial steps were also taken in FY 2004 to meet company quality and copyright requirements for unique software applications like the DMT.

Funding for data entry is limited at this time. As a result, the total number of records entered in each respective database varies. The archaeological database currently contains 1527 records, nine of which were entered in FY 2004. The historical database contains 552 records, 70 of which were modified in FY 2004 to reflect changes as a result of accelerated cleanup activities across the Site. The Research database contains 1,855 records. To facilitate data entry in the historical database, a new data entry terminal was set up in FY 2004. Efforts were also begun to add the capability of generating unique reports to meet SHPO reporting requirements.

a. References herein to any specific commercial product, process, or service by trade name, trademark, manufacturer, or otherwise, does not necessarily constitute or imply its endorsement, recommendation, or favoring by the U.S. Government, any agency thereof, or any company affiliated with the Idaho National Engineering and Environmental Laboratory. 


\subsubsection{INEEL Archive Management}

Work to establish an INEEL Archive Management Program continued by hosting a meeting with a professional archivist from Los Alamos National Laboratory and soliciting ideas for the preparation of an archive management plan. Meetings with ICP and INEEL records management and photo lab management were held regarding the need to identify hard copies of documents, document types, and photo negatives for retention and preservation. In addition, input was provided to the INEEL Long-Term Stewardship Program regarding the need to preserve INEEL archives as part of their overall scope. A tour of the INEEL records facility was conducted to identify current practices that might be modified to accommodate the retention and preservation of and access to archival materials. In anticipation of establishing a formal archive, the CRM office has continued to collect items and documents on an ad hoc basis.

\subsubsection{INEEL Historic Contexts}

"A historic context is an organizational format that groups information about related historic properties, based on a theme, geographic limits and chronological period. A single historic context describes one or more aspects of the historic development of an area, considering history, architecture, archeology, engineering and culture; and identifies the significant patterns that individual historic properties represent. A set of historic contexts is a comprehensive summary of all aspects of the history of the area." (Secretary of Interior's Standards and Guidelines, 48 FR 190).

Well-developed contexts provide the framework within which properties are evaluated for eligibility for listing on the National Register of Historic Places. Six broad context "domains" are presently identified for the INEEL Site:

1. Prehistoric/Protohistoric

2. Euro-American Contact and Settlement

3. Naval Ordnance Testing

4. Nuclear Reactor Testing

5. Post-Reactor Testing Research and Development

6. Waste Remediation.

It is understood that formal written contexts for each of these domains are dynamic documents that will change with the addition of new data and with shifting perceptions within national and international contexts. At present, formal contexts are at various stages of development; however, in FY 2004 a significant milestone was met with finalization of The Idaho National Environmental and Engineering Laboratory, A Historical Context and Assessment, Narrative and Inventory (INEEL 2003). This publication specifically focused on updating the 1998 draft report and fully developing Domains 4-6, including detailed inventories of relevant associated INEEL architectural properties. Although not yet published, A Paleoindian Context for the Idaho National Engineering and Environmental Laboratory was completed in FY 2004, updating portions of a research design developed by a subcontractor in 1986. Additional work is needed to update and expand other aspects of the Prehistoric/Protohistoric domain, as well as for the Euro-American Contact and Settlement period and Naval Ordnance Testing. 


\subsubsection{Curation}

The DOE Idaho is responsible for the management of artifacts and documents located on or removed from the INEEL Site. DOE is required to ensure that collections of these artifacts remain the property of the United States and are preserved in a qualified repository. A contract (Order for Supplies or Services) between DOE Idaho and the Idaho Museum of Natural History (IMNH) to address the backlog of artifacts in temporary storage at the Museum is presently in place. Beginning in FY 2004, this contract remains in effect through February 28, 2008, and appropriates $\$ 7,000$ per year for each of the five years to cover the cost of services for processing and accessioning artifacts that are currently held at the Museum. DOE Idaho collections have been reconciled and data entry is underway. In addition to items presently stored at the IMNH, a number of artifacts are presently in interim storage at the INEEL. These must be inventoried, processed, and transferred, along with associated documentation, to the IMNH for accessioning. FY 2004 activities related to items in interim storage at the INEEL included preparation of a draft interim storage plan and a proposal for additional funding to complete these tasks. In addition, a process to identify nuclear-era artifacts was implemented, some items were moved to interim storage and efforts are underway to identify long-term storage facilities to house and possibly display and interpret these unique items.

\subsubsection{Regulatory and Requirements Reviews}

Work at the INEEL Site is guided by literally hundreds of external and internal requirements and procedures with cultural resource management requirements being well integrated into the overall environmental compliance system. New requirements and procedures and changes to existing requirements and procedures are continuously tracked and undergo company-wide impact reviews by subject matter experts. In FY 2004, over 50 of these reviews were conducted by the CRMO subject matter experts for potential impacts to cultural resources or for impacts to CRM compliance processes at the Site and comments were subsequently incorporated into several document revisions.

\subsubsection{Cultural Resource Protection}

A variety of activities falling under the broad topic of cultural resource protection were completed in FY 2004, meeting several specific and recurring CRMO goals. Most of these activities are ongoing efforts and include the following:

- Began to assemble histories for unimproved roads designated as "Priority 3" for maintenance (spot grade and gravel) to provide information necessary to assess the impacts of this maintenance approach. Historic information was gathered for the following roads: T-1 (Goodale's Cutoff), T-2, T-3, T-4, T-5, T-6, T-9, T-10, T-11, T-16, T-20. A report on this research is expected to be completed in FY 2005.

- Assembled list of significant architectural and nonarchitectural cultural resources in and around the Central Facilities Area (CFA) as a first step in developing a Site Protection Plan for this facility.

- Conducted numerous "Cultural Resource Protection" training sessions for Site employees (e.g., ecological field teams, emergency responders, Site management, university researchers, heavy equipment operators at ARA and PBF, etc.).

- Developed a permitting program to address ARPA requirements. (Presently undergoing legal review) 
- In 2004, a cultural resources training module was incorporated into "Blue-Card Training," known formally as INEEL ESHQ/ISM/VPP and Site Access Training. All current employees received the training during the annual refresher, and all new hires now receive it as a part of their orientation. 


\section{STAKEHOLDER AND PUBLIC OUTREACH}

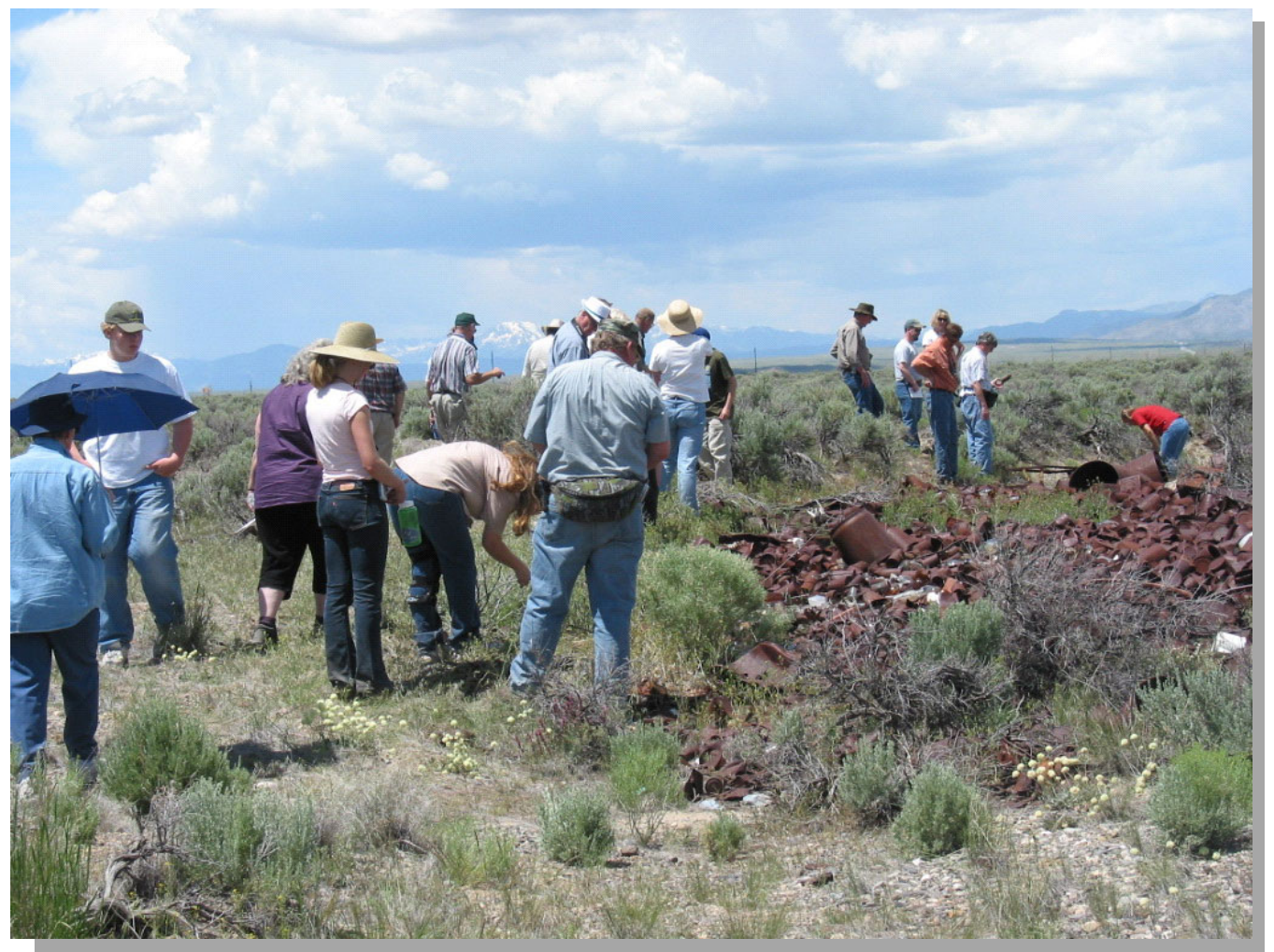

Public Tour Examining a WWII Historic Site on the INEEL

As a federal agency, DOE is required by a number of statutes, most importantly the National Historic Preservation Act, to manage INEEL Site cultural resources in a spirit of stewardship for the citizens of the United States and to provide those citizens an opportunity to become involved in the cultural resource management process. Systematic planning for public participation in Site cultural resource management will help ensure that such participation takes place routinely and productively, and that public interests regarding resource preservation and interpretation will be considered as the Laboratory executes its primary missions. Finally, the list of potential stakeholders is as varied as the resources themselves, including such diverse groups as local historical societies, museum associations, Oregon Trail enthusiasts, INEEL retirees, historical and scientific researchers, Native American tribes, and the general public. Because of the special relationship between DOE Idaho and the Shoshone-Bannock Tribes, tribal outreach and participation are discussed in Section 7.

\subsection{Communication Strategies}

The Cultural Resource Management staff members recognize that successful communication is more than simply the release of technically correct information. In order to facilitate meaningful stakeholder and public discourse the following strategies are implemented:

- $\quad$ Evaluate and assess the communication environment, political environment, and the decision making process and the role of stakeholders that process

- Seek every available opportunity and use multiple communication vehicles to share information about cultural resources and activities that may affect them. 
During FY 2004, these strategies were implemented through tours, presentations, and participation in local and regional historic preservation activities. This work was completed with both direct and indirect funding and on a voluntary basis that reflects the CRM staff's commitment to the protection of cultural resources and to public education.

\subsection{Completed Activities for FY 2004}

The following list of activities conducted in FY 2004 correspond to specific tasks or milestones as well as to the overall tribal involvement philosophy.

\subsubsection{Stakeholder Involvement Plan}

During FY 2004, the CRM office developed an INEEL Cultural Resources Stakeholder Involvement Plan (Draft) in order to:

- $\quad$ Ensure timely communication with stakeholders and the general public in order to promote increased interaction, understanding, and cooperation on issues of mutual concern

- $\quad$ Ensure compliance with all applicable federal and state laws, regulations, DOE agreements and directives that require reciprocal, open, and sincere exchanges of information prior to an agency's undertaking.

\subsubsection{Tours}

The CRM office conducted eleven formal tours:

- DOE Chief Historians' tour of Signature Properties

- $\quad$ State Historic Preservation Office and Advisory Council to discuss the CRM Plan and programmatic agreement

- $\quad$ Two public tours associated with Idaho Archaeology and Historic Preservation Month to increase awareness of cultural resource protection on the INEEL Site

- Idaho Historic Sites Review Board tour

- $\quad$ Museum of Idaho Youth Science Camp

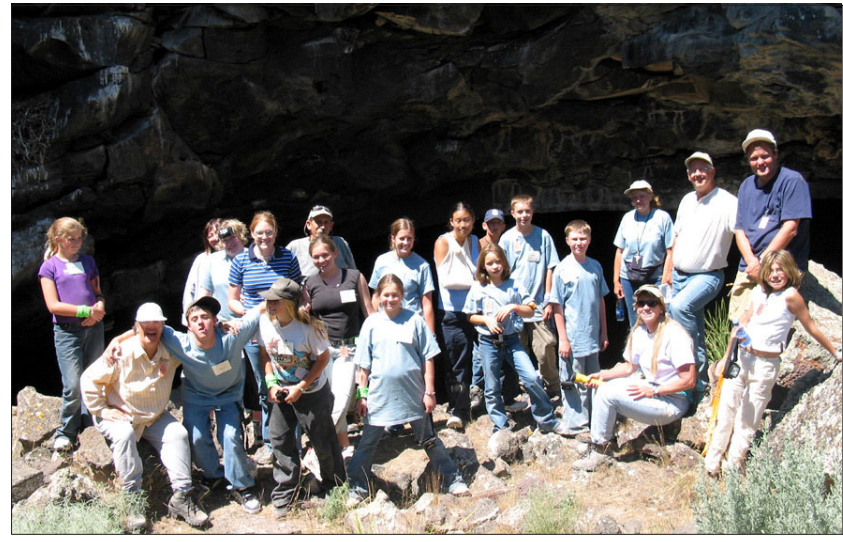

Museum of Idaho Tour Group tour

- ICP Technical Integration Tour to discuss the End State Plan

- University of Utah astrophysics staff tour to discuss collaborations

- University of Oklahoma geophysics students and professors tour of INEEL archaeological sites

- $\quad$ BBWI Emergency Management - tour of INEEL archaeological sites for ARPA education

- $\quad$ DOE Idaho and DOE-HQ - cave and archaeological site tour. 


\subsubsection{Presentations and Press Releases}

The CRM office staff visited schools, community organizations, universities, other institutions, and professional conferences to educate people about INEEL CRM activities and share knowledge about INEEL Site cultural resources. Such presentations included:

- "Relics of Flight: from Wright to Wrong," Goucher College

- $\quad$ "The Idaho National Laboratory: Preserving Elements of the Recent Past" at University of Oregon Preservation Field School, Harriman State Park

- "Somewhere Between the Mountain and the Ant: A Comparison Between Northwest Native American and Euro-American Salmon Economies," ISU, Land Issues Seminar

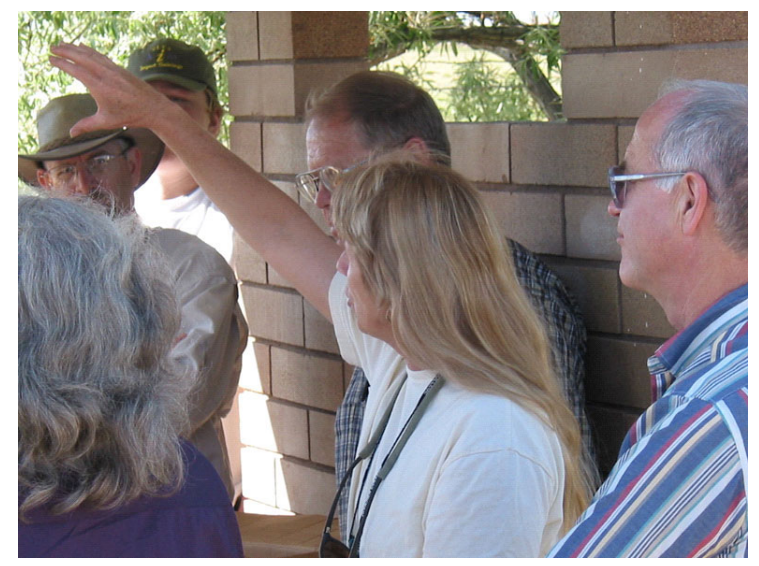

Presentation on Snake River Plain Geology

- "Nature Versus Nurture: Exploring the Territory Between Culture and Genes," ISU, Philosophy of Social Science Seminar

- "The Natural History of Bats on the INEEL," various locations

- $\quad$ Treasure Valley Business Leaders, cultural resources of the INEEL

- Idaho Economic Development Council, cultural resources of the INEEL

- $\quad$ Society for American Archaeology: "Analyzing Land Use Changes Over Time Using GIS and Projectile Point Typology" (poster presentation)

- $\quad$ "Testing a GIS Predictive Model of Archaeological Sites and Its Potential Research Applications for the Upper Snake River Basin in Eastern Idaho," 19th Annual Northwest GIS Users Conference, September 2004, Sun Valley, ID (Award winning poster)

- "Archaeological Applications in Geophysics," 30th Annual Idaho Archaeological Society Conference, October 2003, Boise, ID

- “Archaeological Geophysics," INEEL Subsurface Science Seminar and lobby display, November 2003, Idaho Falls, ID

- "Historic Preservation in Idaho Falls," Idaho Falls Exchange Club, January 2004, Idaho Falls, ID

- "INEEL Initiatives in Archaeological Geophysics," Idaho State University Department of Geology Colloquium, January 2004, Pocatello, ID

- "Careers in Archaeology and Anthropology," Claire E. Gail Jr. High Career Days, March 2004, Idaho Falls, ID

- $\quad$ "Eyes of the Beholder: GIS as a Tool to Understand and Manage Diverse Landscapes on the Northeastern Snake River Plain," 69th Annual Society for American Archaeology Conference, March 2004, Montreal, Canada 
- "Testing a GIS Predictive Model of Archaeological Sites for the Upper Snake River Basin in Eastern Idaho," 69th Annual Society for American Archaeology Conference, March 2004, Montreal, Canada

- “Archaeological Sensitivity Training,” Long Term Ecological Sampling Field Team, June 2004, INEEL Site

- “ Talkin’ Trash:” A World War II dump on the INEEL—Idaho Archaeological Society

- $\quad$ Presentation on Late Pleistocene/Early Holocene human land use on the Eastern Snake

River Plain-Idaho State University

- $\quad$ Presentation on The National Historic Preservation Act and National Environmental Policy Act and how they relate to each other-Idaho State University

- $\quad$ Presentations on Cultural Landscapes-Idaho State University

- $\quad$ 100th anniversary of flight and Nuclear Aircraft—KIDK TV interview

- Numerous internal training sessions on CRM compliance responsibilities for project managers, DOE managers and relevant technical personnel

- "INEEL develops computer tool to help save archaeological treasures," DOE News Release, local radio interview, DOE Pulse article, internal INEEL employee article (iLights), August/September 2004

- "INEEL hosts tour of its archaeological, historical sites," DOE News Release, April 2004.

\subsubsection{Professional Activities}

INEEL CRM Office staff members conduct a variety of professional activities and serve in numerous capacities in local, regional, and national cultural resource organizations. For example, individual memberships are maintained in the Society for American Archaeology, the Idaho State Historical Society, Idaho Professional Archaeological Council, Idaho Archaeological Society, and the Bonneville County Historical Society. The majority of these efforts are unfunded, completed by CRMO Staff at their own discretion. Below is an abbreviated list of additional professional activities completed in FY 2004.

- $\quad$ Provided technical consultation on Pleistocene and Holocene exhibits at the Museum of Idaho

- $\quad$ Provided technical support to preservation projects at the Wasden Site, near Camas Creek, and near the Blackfoot Reservoir

- $\quad$ Served in a grant reviewer and in an advisory capacity on new exhibits at EBR-I and nuclear history-related exhibits at the Museum of Idaho

- Helped host an archaeology workshop for nonprofessionals, Mesa Falls, Island Park

- $\quad$ Bureau of Land Management Resource Advisory Council

- $\quad$ Adjunct Faculty, Idaho State University

- $\quad$ Registered Professional Archaeologist 
- Chair, Idaho Falls Historic Preservation Commission

- $\quad$ Member, Idaho Historic Sites Review Board

- $\quad$ Officer, Bonneville County Historical Society-Museum of Idaho Board of Directors.

\subsubsection{Preservation Partnerships}

In FY 2004, the INEEL CRM Office furthered two significant and multifaceted cooperative efforts focused on preservation. One important effort involved many integrated partnerships supporting a "Save America's Treasures" grant for the EBR-I National Landmark and related Murdock Trust Foundation grant for EBR-I and Museum of Idaho exhibits in Idaho Falls. These partnerships will help to keep INEEL history vital and visible throughout the region and will continue into FY 2005. In a second partnership, Educational Outreach funds provided support for Idaho State University students and faculty to collaborate with INEEL archaeologists to finalize a three-year effort to produce a Geographical Information System-based archaeological predictive model, and train and educate students in basic cultural resource management practices. Another notable cooperative venture between the INEEL CRM Office, the Idaho Bureau of Land Management, and the University of Oregon focused on archaeological and geophysical investigations of a lava tube cave in southern Idaho.

The following groups were involved in the various efforts conducted in FY 2004:

- $\quad$ Atomic Heritage Foundation

- $\quad$ Museum of Idaho

- $\quad$ Arco Science Center Group

- $\quad$ Murdock Trust Foundation

- $\quad$ Idaho State University

- Shoshone District Bureau of Land Management

- University of Oregon.

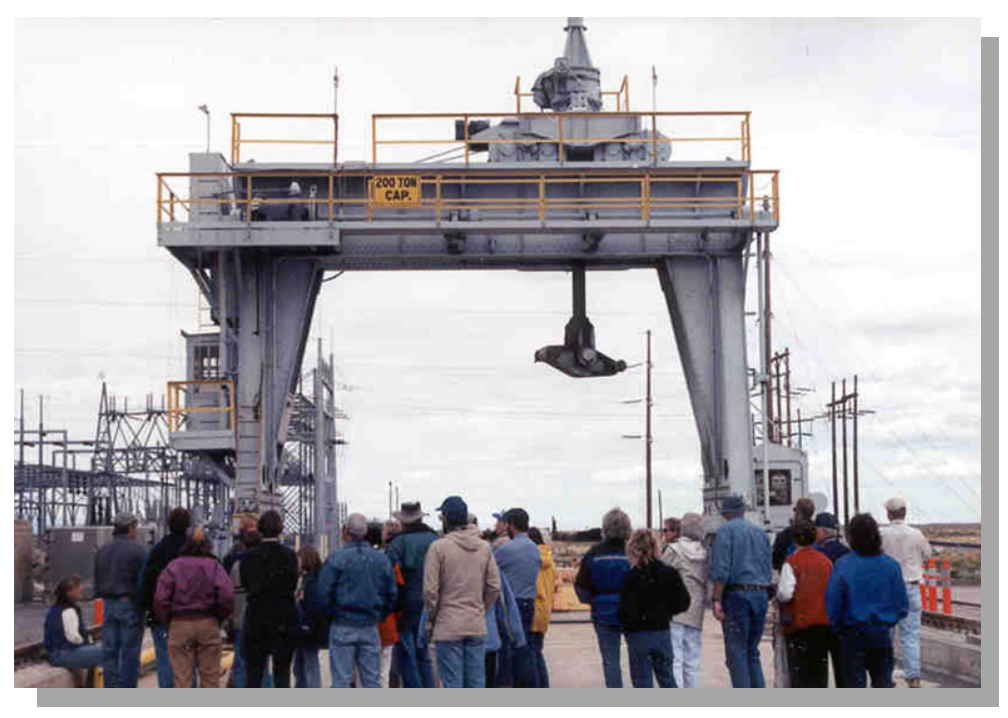

Public Tour at WWII Naval Ordnance Testing Facilities 


\section{NATIVE AMERICAN PARTICIPATION}

As a federal agency, DOE Idaho recognizes its trust responsibility to the Shoshone-Bannock Tribes and in the spirit of that responsibility DOE Idaho has entered into an Agreement in Principle (AIP) with the Tribes. The AIP defines working relationships between the Shoshone-Bannock Tribes and DOE Idaho and fosters a mutual understanding and commitment to facilitate confidence that activities being conducted at the INEEL Site protect the health, safety, environment, and cultural resources of the Tribes. To aid with implementing cultural resource aspects of the AIP, cultural resources protection on the INEEL Site is coordinated through the Cultural Resources Working Group (CRWG) with representatives from the Shoshone-Bannock Heritage Tribal Office (HeTO), DOE Idaho, and the INEEL contractor CRM Office. Regular meetings of this group help to ensure that issues and opportunities are addressed in an environment of mutual respect and learning. Tribal input is sought for new and ongoing Site projects and a standing invitation is extended to comment on, visit, observe, and/or assist in cultural resource management field activity. The holistic view of cultural resources and cooperative spirit encouraged in this group are designed to enhance understanding and appreciation of all types of cultural resources, both within the INEEL community and the Tribes. In an effort to gain a broader understanding of the importance of the INEEL Site landscape and resources to the Shoshone-Bannock Tribes, the INEEL CRM Office has partnered with the Shoshoni Language Project at Idaho State University to begin to assemble a list of Shoshoni and Paiute place-names on and around the Site. Indian and non-Indian students under the direction of Shoshone elder and fluent speaker, Drusilla Gould, have assisted in this work, visiting the INEEL Site on many occasions for direct observation. In FY 2004, a listing of over 300 translations of Shoshoni terms and concepts was created (Plager et al. 2004). This work represents an ongoing commitment by the CRM Office to a holistic concept of cultural resources. For more detail on the special relationship between the INEEL and the Tribes, and detailed working procedures, see Appendix B of the Idaho National Engineering and Environmental Laboratory Cultural Resource Management Plan (DOE-ID 2004).

During FY 2004 the CRMO staff was represented at all scheduled CRWG meetings and HeTO staff were otherwise informed of INEEL Site activities pertinent to cultural resources through preparation and transmittal of quarterly activity reports. HeTO staff members were also regularly invited to participate in survey and monitoring fieldwork.

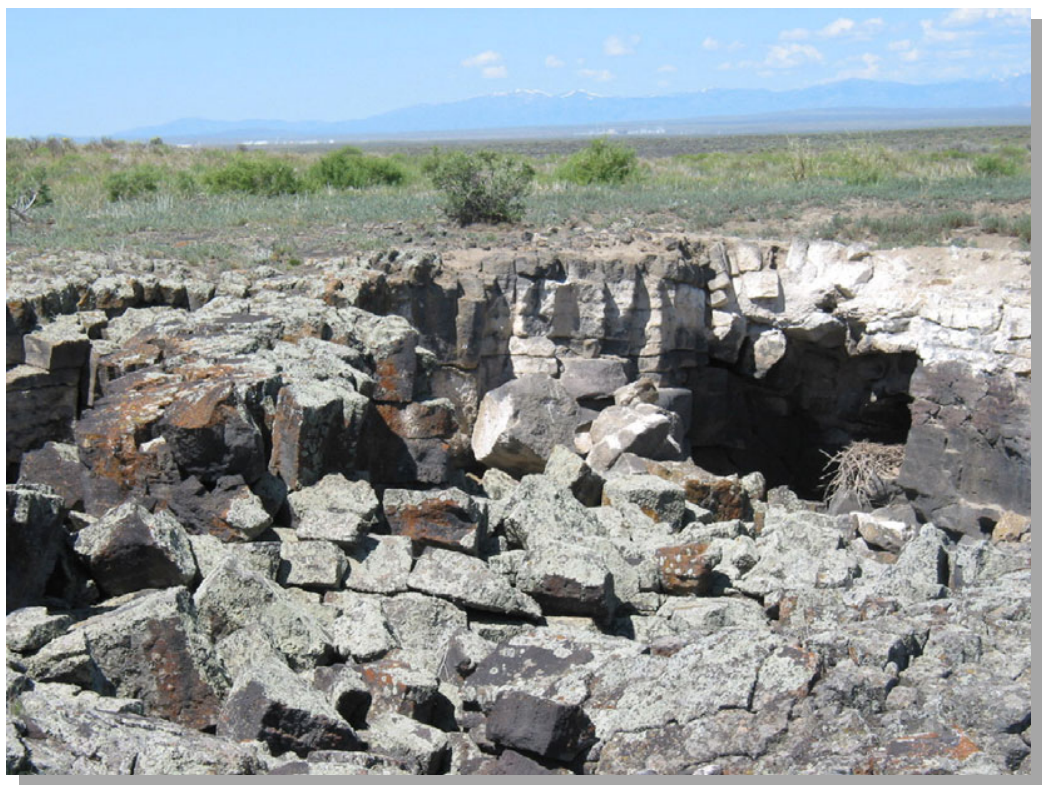

Aviators' Cave 


\section{Heritage Tribal Office Staff}

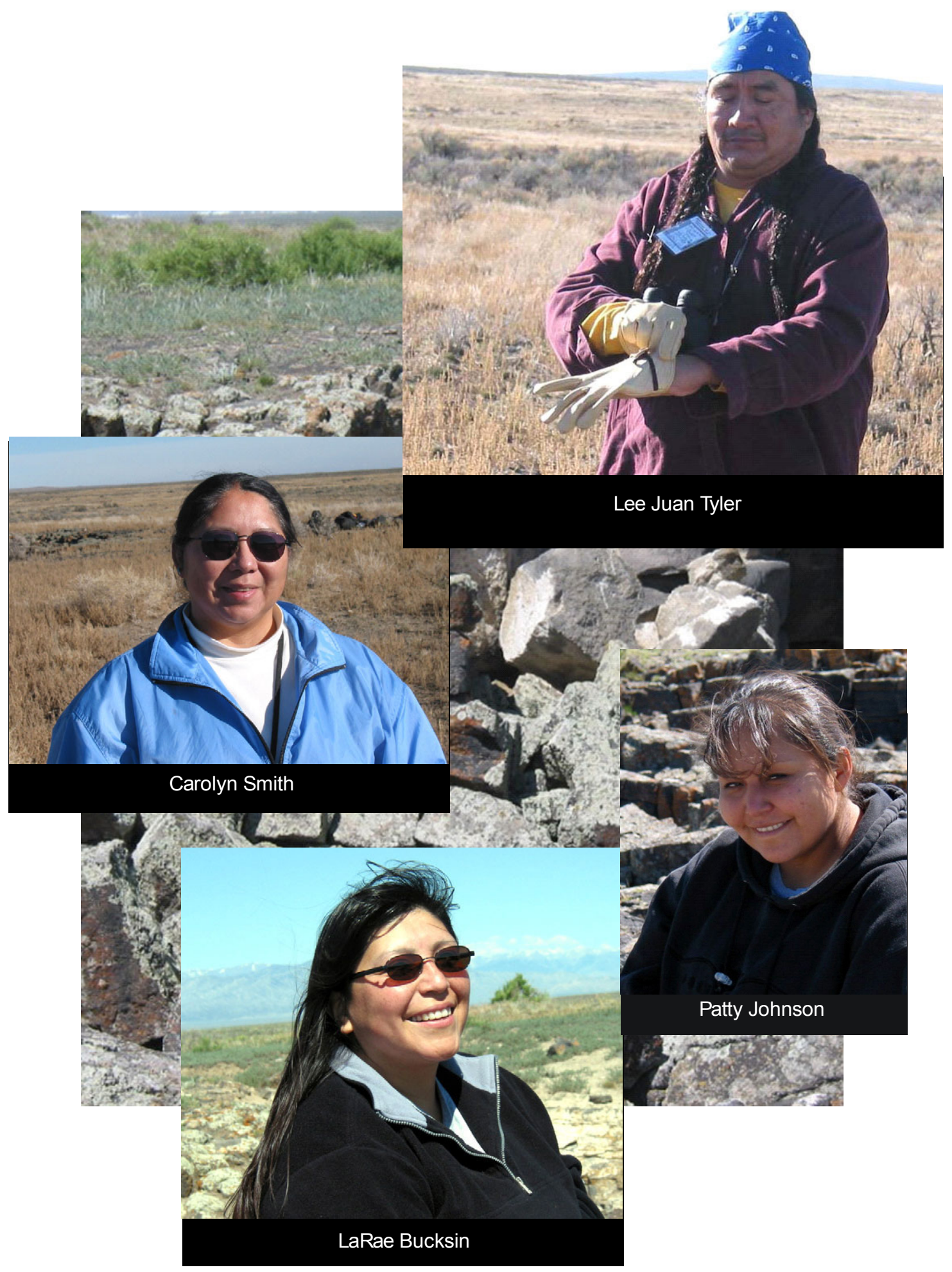




\section{PROJECT REVIEWS}

\subsection{NHPA Section 106 Project Reviews (Historic Architectural)}

The INEEL Site contains various property types that are elements of, or have features that contribute to, the overall landscape and understanding of the INEEL's recent World War II and pioneering nuclear history (1942-1970). The need to clean up the residual waste left by these past activities and processes has resulted in the removal of many buildings and structures and has been the main focus of the project reviews in FY 2004. Due to the nature of the cleanup work and that the INEEL remains an active scientific and technical facility, such activities have impacted, or may impact, historic Site architectural properties.

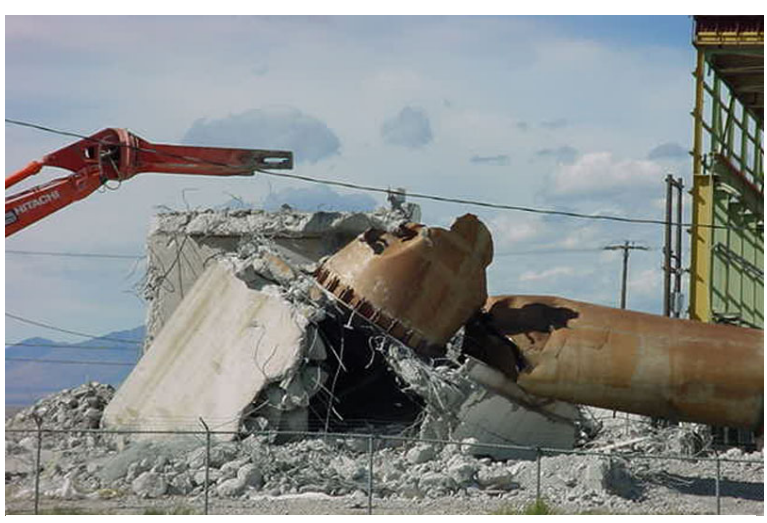

Demolition of the Water Research Reactor Test Facility

As discussed in the INEEL Cultural Resources Management Plan (CRMP), cultural resource reviews are completed as part of the environmental review process to assess impacts to both architectural and nonarchitectural resources. FY 2004 reviews for projects impacting nonarchitectural resources are summarized in Section 8.2. For historic architectural properties (i.e., buildings, structures, equipment, and records) a cultural resource review is initiated whenever one of the following thresholds is met:

- Demolition, major structural or landscape modification, or permanent closure of extant buildings and structures and/or removal of original equipment, features, or records

- $\quad$ Any activities that may affect the Experimental Breeder Reactor-I facility area, a National Historic Landmark.

The goal of the cultural resource review is to determine if the proposed project will affect properties that are eligible for the National Register of Historic Places, if they are Category 1, 2, 3, or "Signature" properties based on their relative historic importance; and, if so, to complete the mitigation and/or consultation measures outlined in the INEEL CRMP. The process used to make this determination includes archive and record searches and survey.

Nearly all of the INEEL Site architectural properties project reviews conducted in FY 2004 resulted from acceleration of decontamination, deactivation, and demolition (DD\&D) ofactivities related to Site buildings and structures. Such acceleration meant that project reviews were conducted prior to the removal of 88 Site buildings and structures in FY 2004. Although consultation was conducted for some of these properties in years prior to 2004, the CRM Office staff provided the history and results of this consultation to DOE Idaho and contractor project managers, and advised them on whether or not compliance had been achieved in the cases where Memoranda of Agreement (MOA) were developed.

Of the 88 buildings and structures that were reviewed and underwent DD\&D in FY 2004, 28 were exempted from the cultural resource review process, 33 were not historic, and 27 were historic. Five MOA, between the DOE Idaho and the Idaho State Historic Preservation Office (SHPO) were produced in FY 2004 and guided the mitigation of most of these properties. Mitigation activities conducted in FY 2004, included the completion of two draft Historic American Engineering Record (HAER) reports, one for Test Area North properties and the other for those at the Power Burst Facility area. Documentation was gathered or completed for buildings and structures at the Test Reactor Area and 
the Idaho Nuclear Technology and Engineering Center as required by the FY 2004 and earlier, MOAs for inclusion in HAER reports that are scheduled for completion between FY 2005 and FY 2007.

The Programmatic Agreement signed in July 2004 required that the measures outlined in the CRMP be implemented. Activities proposed after July followed the requirements outlined in the CRMP. Table 8-1 includes the properties that underwent DD\&D, those that are awaiting DD\&D, and status of other project reviews. 


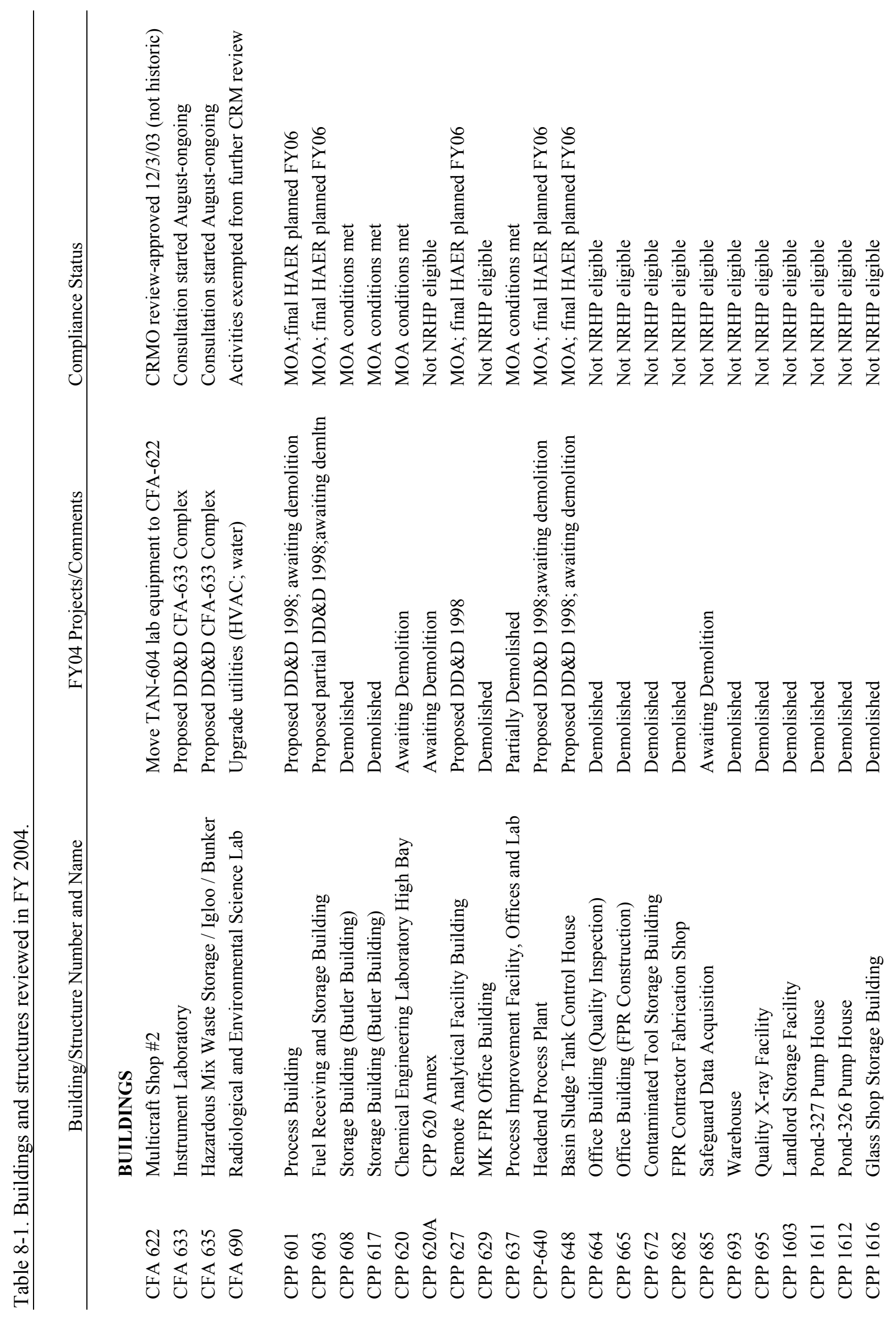




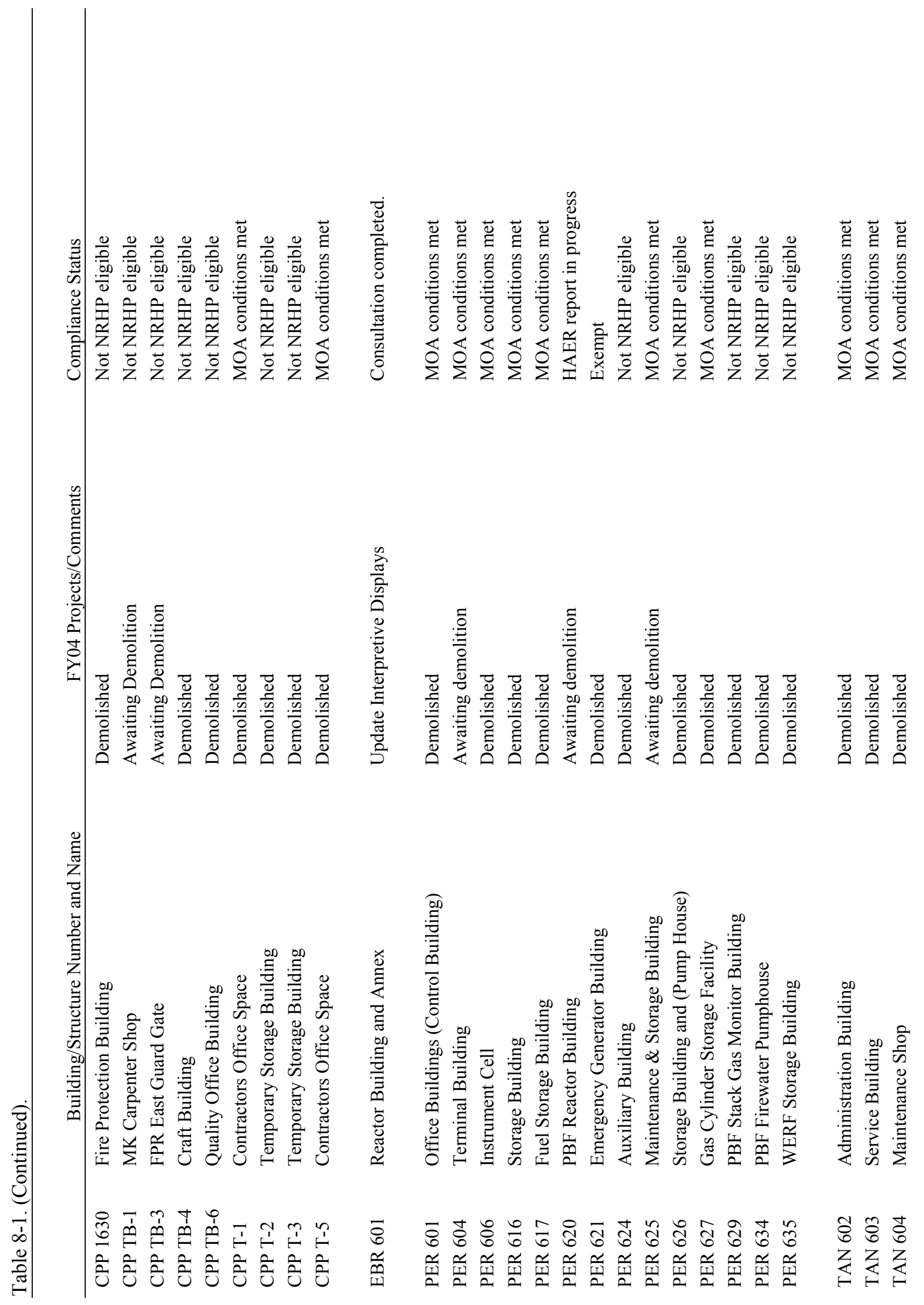




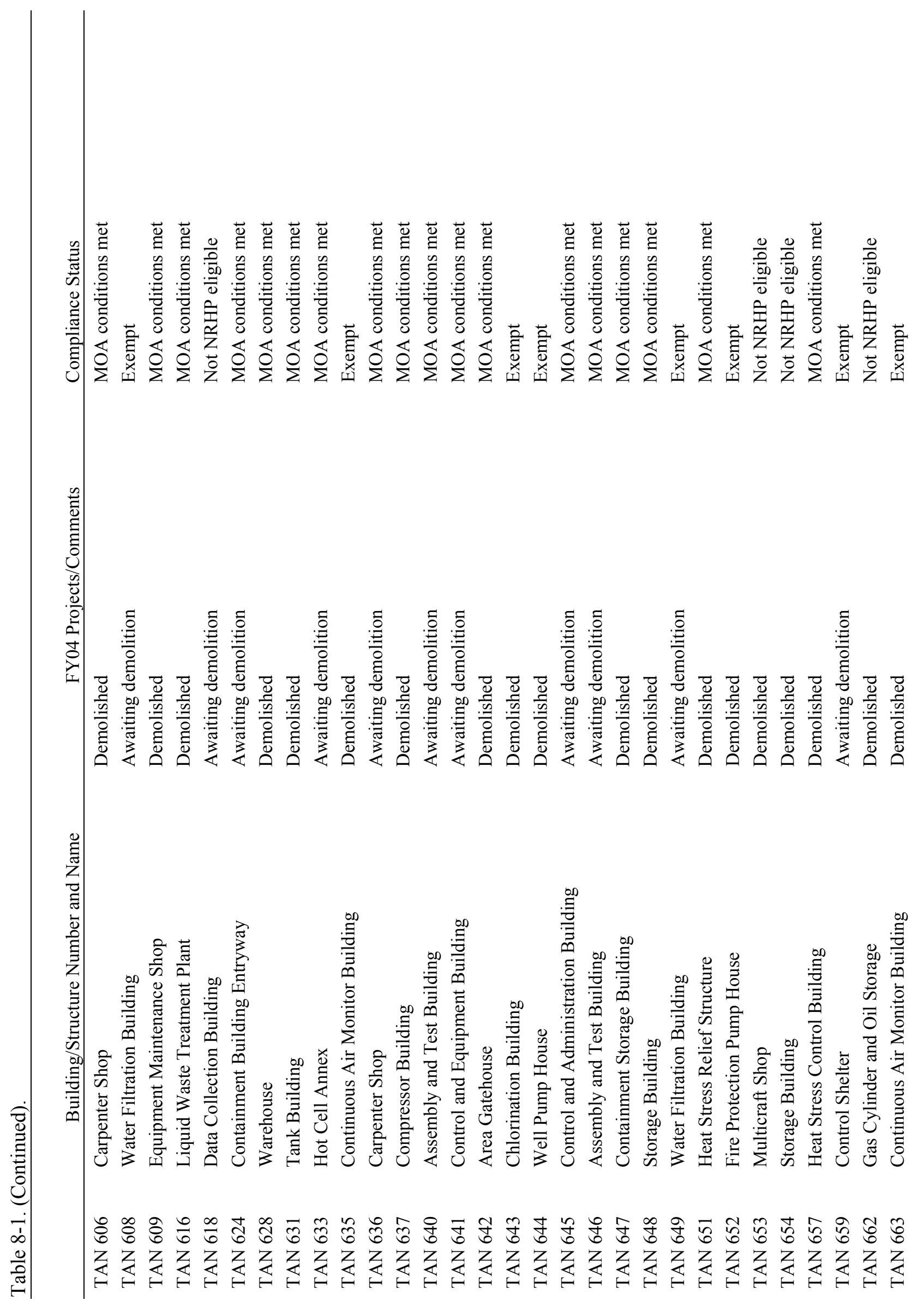




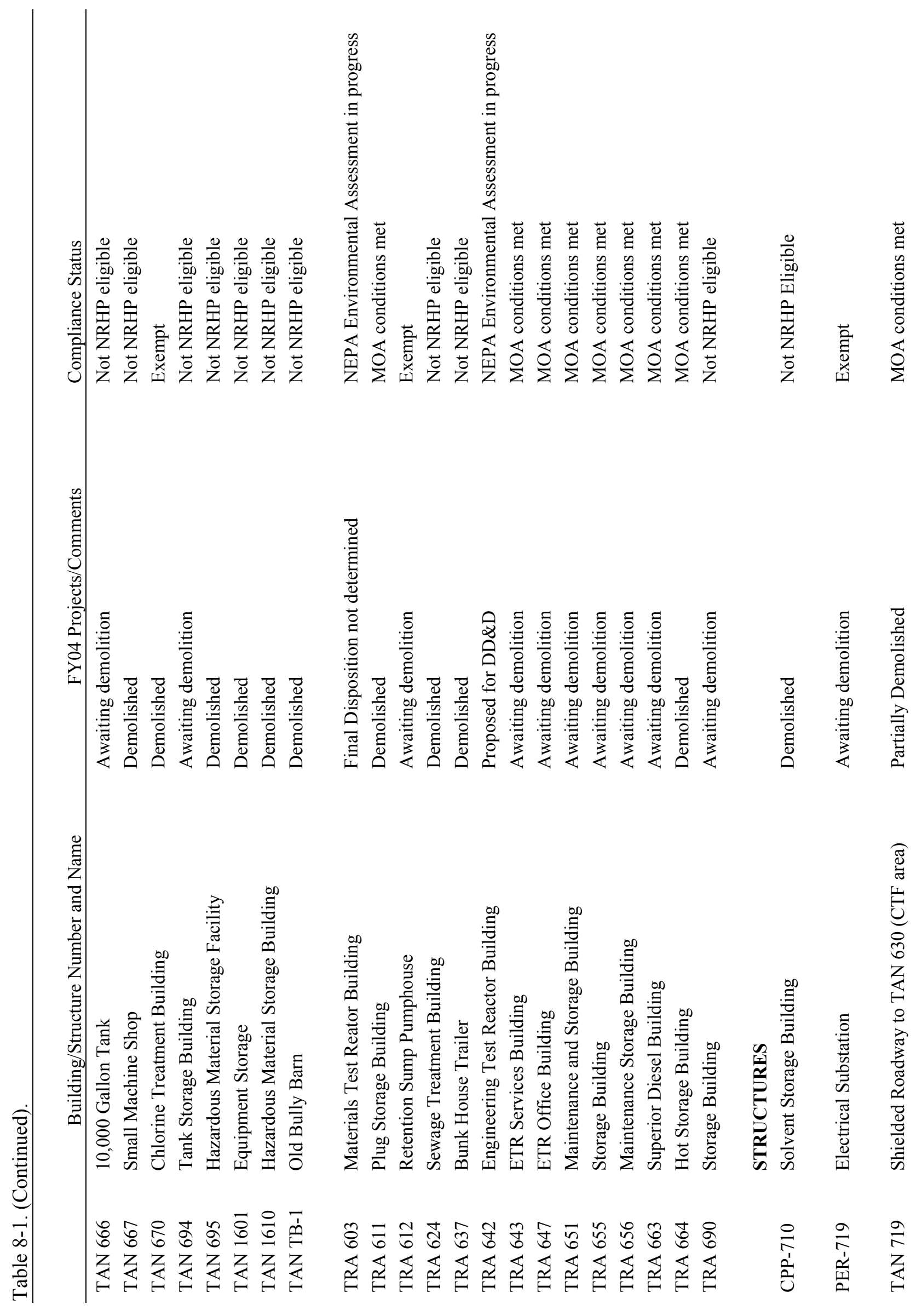




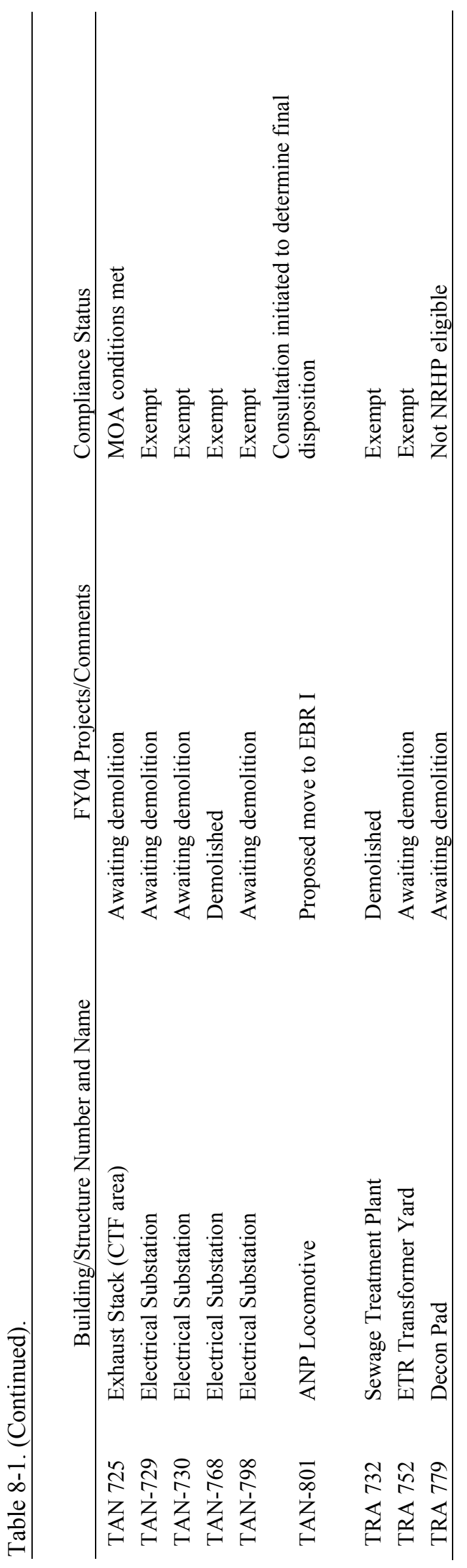




\subsection{NHPA Section 106 Project Reviews (Nonarchitectural)}

The INEEL Site is an active facility where thousands of work orders for projects ranging from lawn mowing to new facility construction are processed each year. Detailed procedures are in place to evaluate the environmental consequences of all activities, large or small. Cultural resource reviews are an integral part of the environmental review process and are completed to assess impacts to both architectural and nonarchitectural resources. FY 2004 reviews for projects impacting architectural resources are summarized in Section 8.1.

For nonarchitectural cultural resources (archaeological sites, traditional cultural properties, roads and trails, etc.), a cultural resource review is prompted whenever one of the following basic thresholds is met:

- Ground disturbance outside the boundaries of fenced INEEL facilities or more than $50 \mathrm{ft}$ from existing buildings or landscaped areas in unfenced areas

- Any ground disturbance within or around the Power Burst Facility, now designated as the Critical Infrastructure Test Range Complex (CITRC)

- Any activities proposed for known or suspected zones of Native American sensitivity and/or high archaeological resource density.

The goal of the cultural resource review is to determine if the proposed project will affect significant, National Register-eligible cultural resources. Techniques used to make this determination include archive and record searches, field surveys, tribal communication, and small-scale test excavation.

In FY 2004, 39 projects were screened for potential impacts to nonarchitectural cultural resources (See Table 8-2). Nearly all of these reviews (62\%) demonstrated that the proposed projects were located within areas that had already been intensively surveyed for cultural resources through archive and record searches, alone. In all of these cases, the projects could be completed with no impacts to known resources of National Register significance either because the original surveys resulted in no resources recorded or because identified resources were clearly outside the area of potential effects for the work. Recommendations for "clearance" were issued for all of these projects with standard stipulations requiring work to stop in the event of any unanticipated discovery of cultural material.

Field surveys were necessary for slightly more than $28 \%$ of FY 2004 projects proposed for areas that had never been surveyed for cultural resources or in areas that were originally surveyed more than ten years ago. Close to 58 acres were intensively examined during these FY 2004 surveys (57.75) and six archaeological resources were documented. The Shoshone-Bannock Tribes visited all of these project locations either during the surveys or on special tours. No special tribal concerns were voiced for any of the projects. Project plans were modified in all cases to avoid all of the archaeological resources identified. Cultural resource clearance recommendations issued for these projects also included a reminder of the requirements to stop work if any cultural materials were unexpectedly encountered.

A small number of the cultural resource reviews completed in FY 2004 (10\%) resulted in recommendations for future work. In these cases, projects were not scheduled for immediate completion and were located in areas that had never been surveyed for cultural resources or in areas where cultural resources are known to exist. Documentation of FY 2004 nonarchitectural cultural reviews consisted of individual project summaries completed and filed for each project. Site recording forms were also completed and electronic archives were updated. 


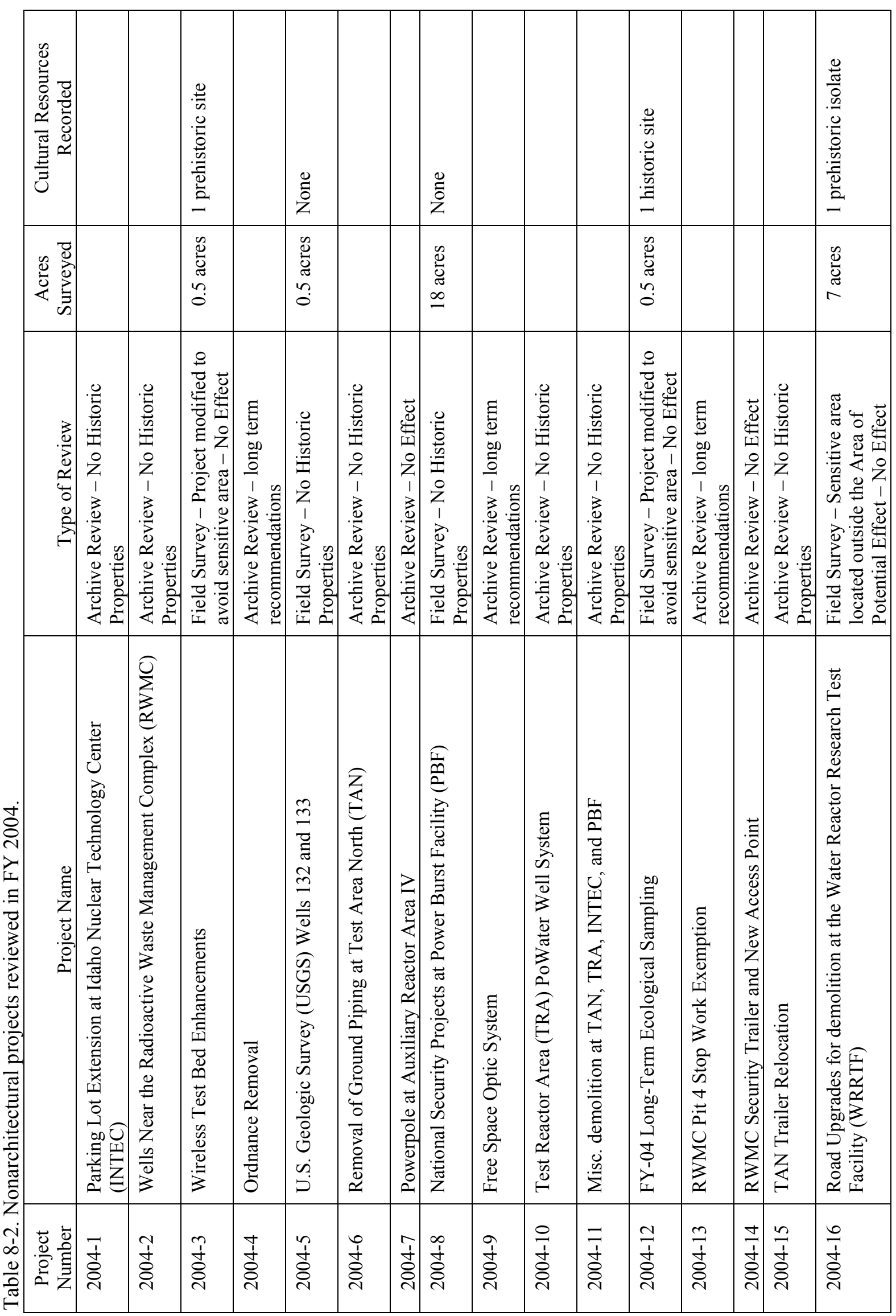




\begin{tabular}{|c|c|c|c|c|c|c|c|c|c|c|c|c|c|c|c|c|c|}
\hline 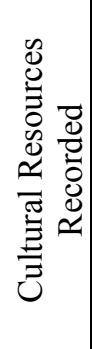 & & & $\begin{array}{l}\mathscr{0} \\
\text { z }\end{array}$ & $\begin{array}{l}\tilde{\Xi} \\
\text { ż }\end{array}$ & 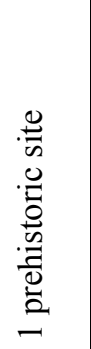 & 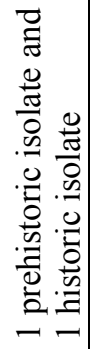 & & & & & & $\begin{array}{l}\mathscr{\Xi} \\
\text { z }\end{array}$ & & & & & 号 \\
\hline 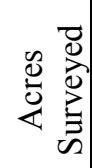 & & & 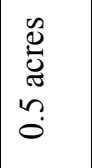 & 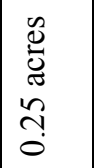 & 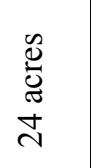 & 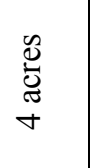 & & & & & & $\begin{array}{l}\tilde{y} \\
0 \\
0 \\
0 \\
n \\
0\end{array}$ & & & & & $\begin{array}{l}\mathscr{8} \\
\stackrel{0}{\pi} \\
\sim \\
\sim\end{array}$ \\
\hline 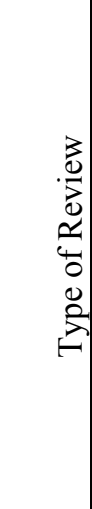 & 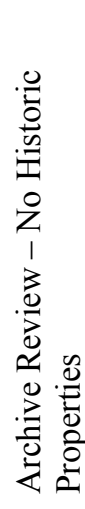 & 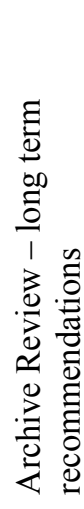 & 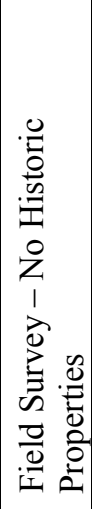 & 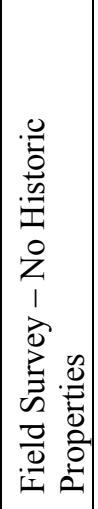 & 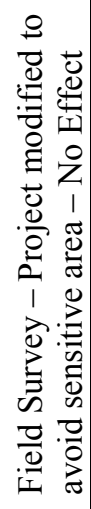 & 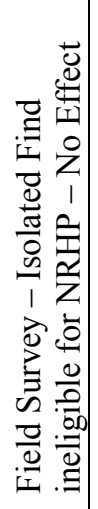 & 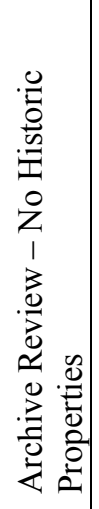 & 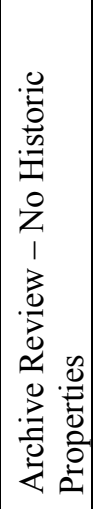 & 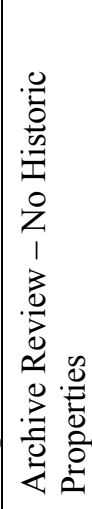 & 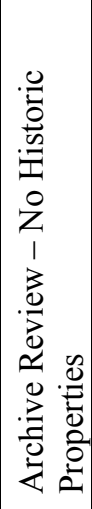 & 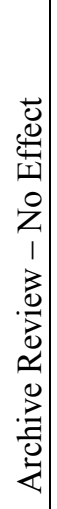 & 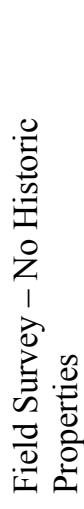 & 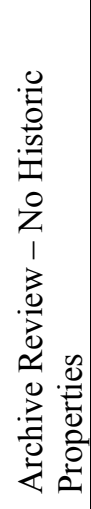 & 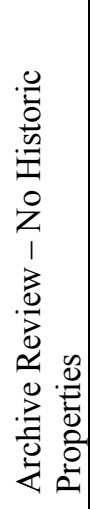 & 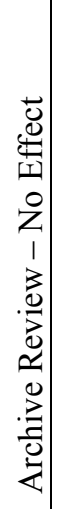 & 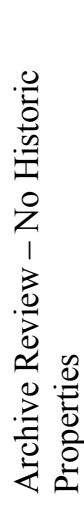 & 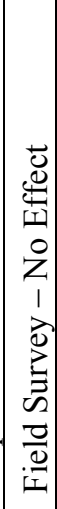 \\
\hline 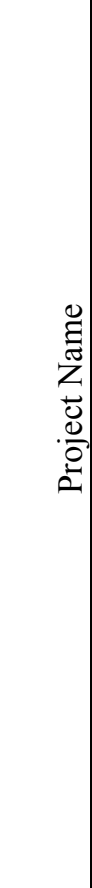 & 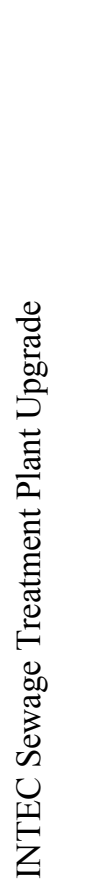 & 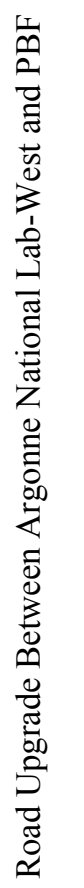 & 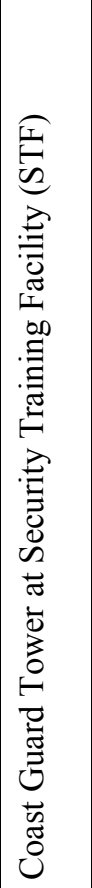 & 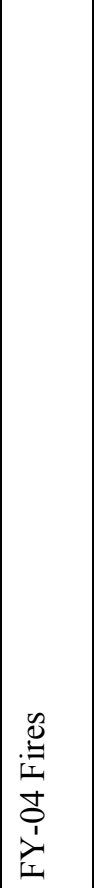 & 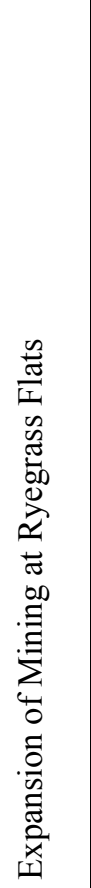 & 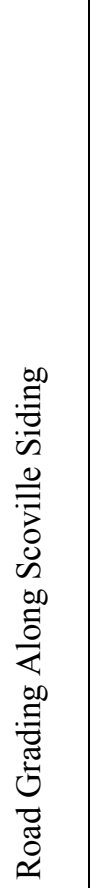 & 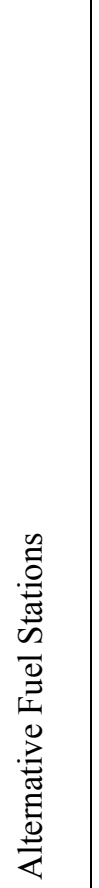 & 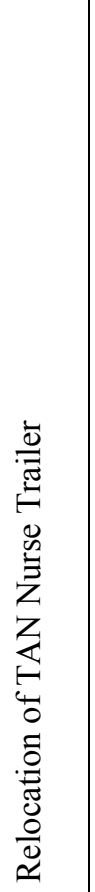 & 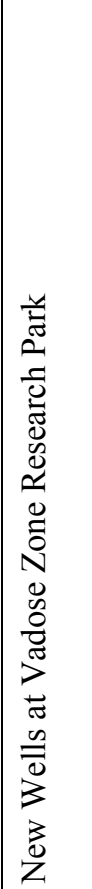 & 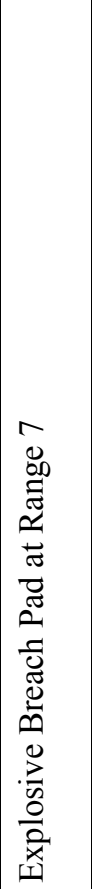 & 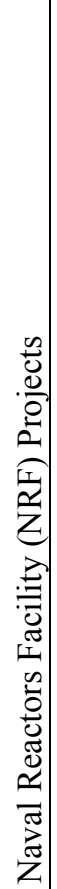 & 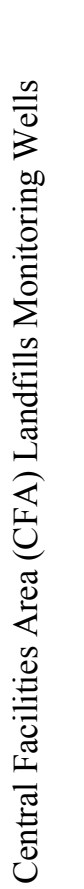 & 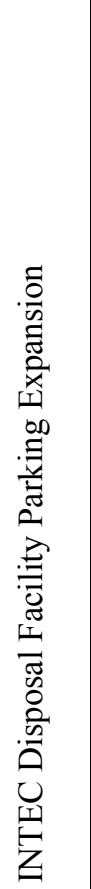 & 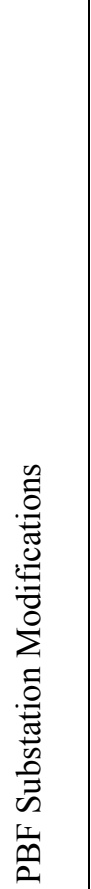 & 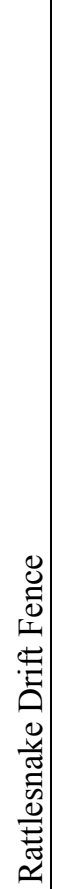 & 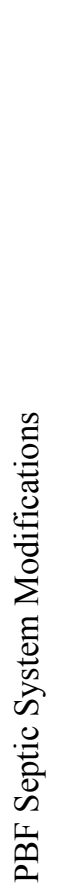 & 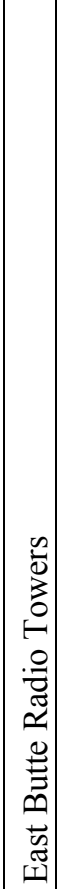 \\
\hline 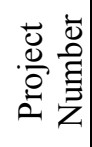 & 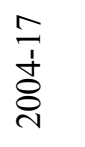 & $\begin{array}{l}\infty \\
\frac{1}{d} \\
\stackrel{d}{d}\end{array}$ & 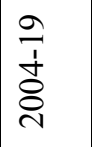 & 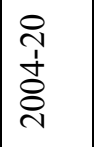 & 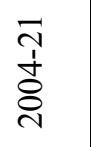 & 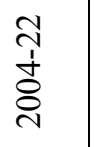 & 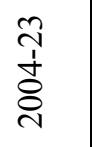 & 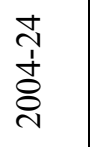 & 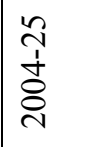 & 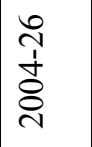 & 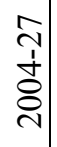 & 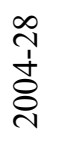 & ते & 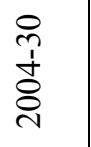 & 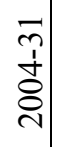 & 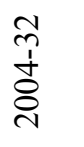 & $\begin{array}{l}m \\
\dot{d} \\
\stackrel{\sim}{0}\end{array}$ \\
\hline
\end{tabular}




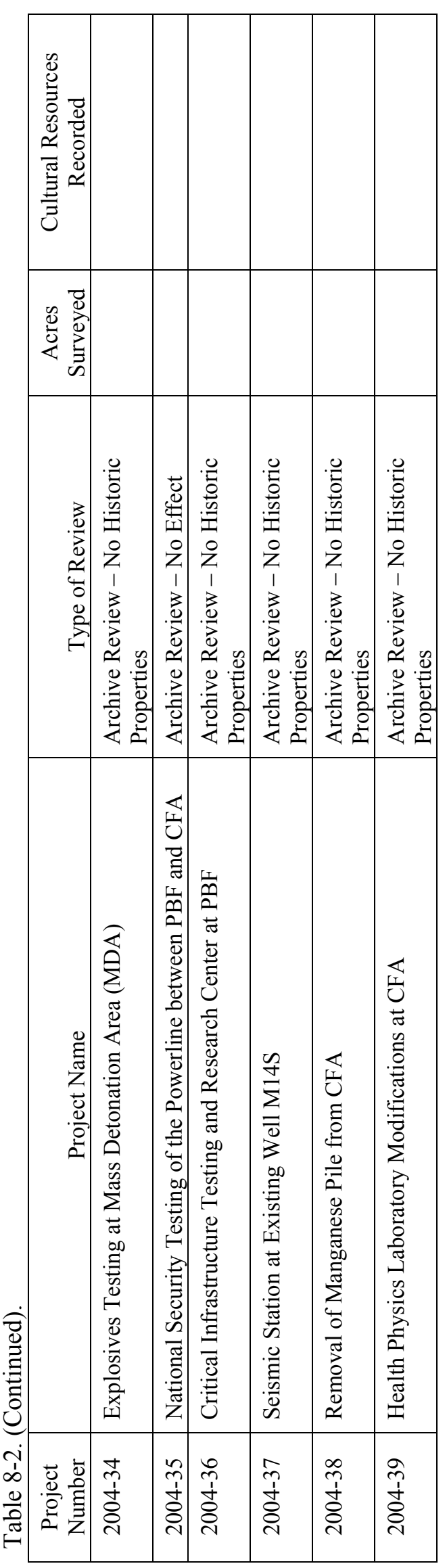


Although no test excavations were completed on the INEEL Site in FY 2004, consultation on one FY 2003 project was finalized. FY 2003 test excavations and geophysical mapping at a small prehistoric lithic scatter located in the middle of an active portion of the INEEL Firing Range revealed no significant subsurface cultural deposits and led to a determination that the site (10-BT-810) is not eligible for nomination to the National Register (Pace 2004). In FY 2004, the report documenting this work and eligibility recommendation was forwarded to the SHPO and Tribes for review. The SHPO concurred with the report and its findings (Neitzel 2004). Although the Tribes participated in all FY 2003 fieldwork, they declined to comment on the project report.

\subsection{NHPA Section 110 Projects}

\subsubsection{FY 2004 Section 110 Survey}

Section 110 of the National Historic Preservation Act (NHPA) directs federal agencies to establish programs to identify, evaluate, and nominate properties under their jurisdiction to the National Register of Historic Places and to maintain and manage such properties in a manner that considers their preservation. To that end, DOE Idaho has committed to a comprehensive cultural resource management approach that addresses all cultural resources on the INEEL Site, regardless of the potential for adverse effects to them.

Every year, newly discovered resources are added to the list of known, cultural resources through two basic processes. The first is the NHPA Section 106 compliance project as described in Sections 8.1 and 8.2. The second process consists of Section 110 resource inventory surveys that address provisions of Section 110 of the NHPA and also of the Archaeological Resources Protection Act that require federal agencies to locate and evaluate all cultural resources on lands they administer. Beyond satisfying compliance requirements, data gathered from these inventories lend themselves to long-term land management planning, resource stewardship, and can help address specific research questions when surveys are conducted under the guidance of appropriate research designs or historic contexts.

The FY 2004 Section 110 archaeological survey targeted the extreme northern reaches of the Big Lost River, a stretch of the river that actually flows north from the Big Lost River Sinks and was once inundated by Pleistocene Lake Terreton. This is an area of the Site that has seen little development since the early 1900s, and consequently has also received little in the way of Section 106 cultural resource survey.

Lake Terreton was a shallow lake that once spread over hundreds of square kilometers, including approximately $233 \mathrm{~km}^{2}$ of the Site (Butler 1970; Gianniny et al. 2002; Miller 1995). Early researchers believed that the Lake Terreton shoreline was generally at an elevation of $4800 \mathrm{ft}$ (Butler 1968; Nace et al. 1972).

During the Pleistocene, particularly at the end of the last glacial maximum at about 18,000 B.P., high discharge flows from the Big Lost River, Little Lost River, and Birch Creek fed a western sub-basin of Pleistocene Lake Terreton. Farther to the east, Camas and Beaver Creeks sustained an eastern sub-basin that is manifest in present-day Mud Lake, located roughly 20 miles east of the study area.

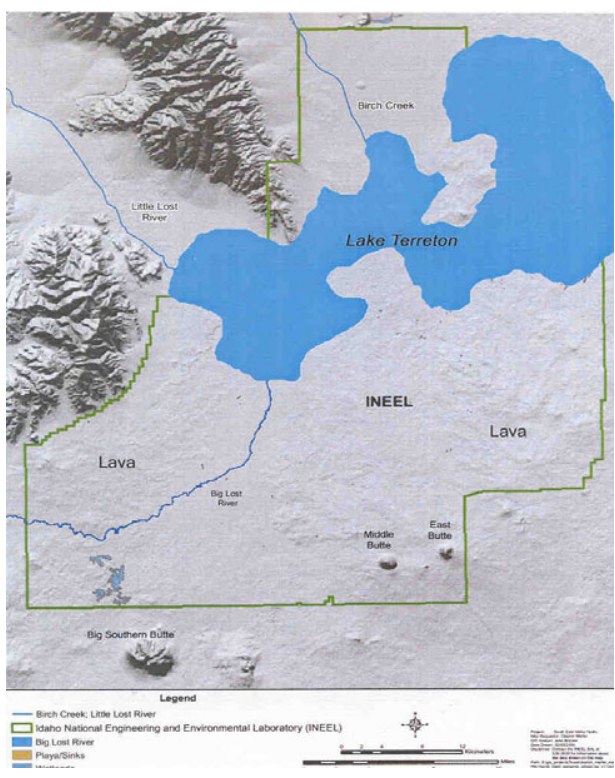

Approximate Location of Lake Terreton 
Although the precise hydrologic history of Lake Terreton is not clearly understood, lake levels during the Quaternary generally appear to have fluctuated in accord with advances and retreats of the nearby montane glaciers (Gianniny et al. 2002). However, palynological studies indicate that significant stands of water may have been present in the Lake Terreton basin as recently as 700 years ago (Bright and Davis 1982).

Recent paleohydrologic and geomorphic studies tend to support this, suggesting a high stand as recently as 1,000 years ago. However, it appears that this event was the only Holocene occurrence. Prior to this, the last high stand probably occurred between about 22,000 and 11,000 years ago (Ostenaa et al. 1999). Regardless of the precise Lake Terreton history, at the end of the Pleistocene and during early Holocene times this northern portion of the Site was likely exceptionally well watered

In terms of human adaptation these conditions yield the possibility of various combinations of riverine and lacustrine adaptations (Marler 2004). Subsequent Holocene warming and drying trends have left a barren, flat expanse of silt and clays, occasionally overlain with sand dunes aligned with the dominant southwesterly winds and variably relieved by sagebrush steppe vegetation (Miller 1995).

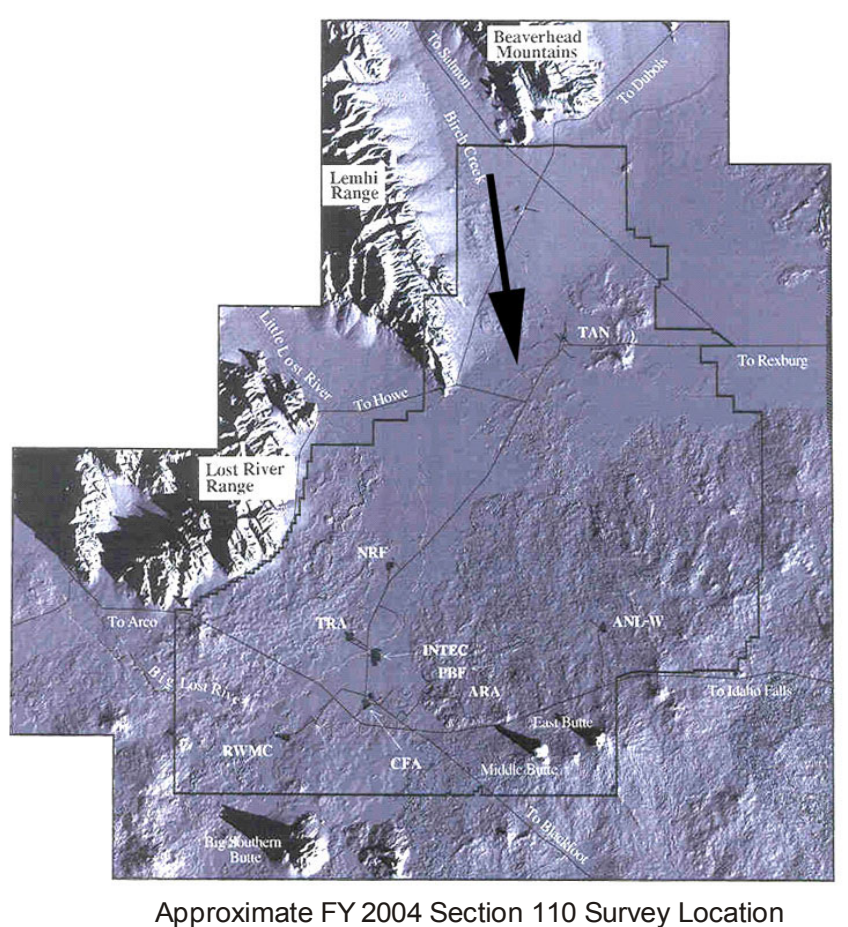

The FY 2004 Section 110 survey was designed as an initial phase of a long-term series of cultural resource inventories in the western Lake Terreton sub-basin and along the probable shoreline to explore what, if anything, the kinds of cultural materials present and their relative locations can tell us about human adaptation and Lake Terreton history during the Late Pleistocene and Holocene and to expand the survey sample from under-studied INEEL Site areas.

\subsubsection{Findings}

Ten sites and six isolated finds were found and recorded during the approximately 150-acre 2004 survey. Of the 10 sites, five contain both historic and prehistoric components, four are prehistoric and one is historic, while all six of the isolates are prehistoric. A total of 31 diagnostic prehistoric artifacts were documented, $90 \%$ of which represent dart technology typically associated with middle prehistoric time period (approximately 7,500-1,500 years ago), 10\% represent arrow technology from the late prehistoric timeframe (approximately 1,500 to 150 years ago). No unequivocal early prehistoric $(15,000$ to 7,500 years ago) artifacts were in evidence. Interestingly, the surveyed area is one that would likely have been under water during peak moisture periods of the Late Pleistocene and Early Holocene.

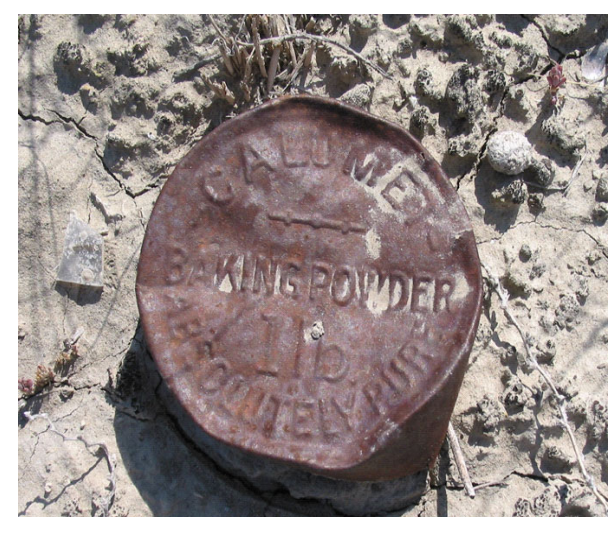

Baking Powder Can from the Blacker Homestead 
During the survey an historic site of particular interest was found and recorded that appeared to be the remnants of a homestead. While there was no permanent foundation, the abundant presence of used (bent and twisted) nails indicated that a structure once stood in the general area. A dense scatter of broken glass, hole-in-top cans and other related cultural refuse and artifacts also indicated evidence of a habitation site. Later research revealed that the homestead most likely belonged to Charles M. Blacker.

According to Bureau of Land Management (BLM) General Land Office (GLO) records, Charles M. Blacker (also listed as Blocher) patented his homestead claim on May 16, 1922 under the 1862 Homestead Act (12 Stat. 392). To file on a claim under this act, the homesteader first needed to be the head of a household and at least 21 years of age. After filing on their claim at the nearest General Land Office (in this case it was located at Blackfoot, Idaho) they were then required to "prove up" on their 160-acre parcel of land. This required building a home and farming their land for five years. If the homesteader made it after five years they could then file a patent. Although there is a discrepancy in Blacker's (Blocher's) name, it is likely that the text was entered incorrectly into the BLM GLO records due to possible bad handwriting.

Blacker, born in Indiana in 1895 was 24 years of age during the 1920 census. This would have made him 26 at the time he patented his claim, making him only 21 when he filed on his claim. While the census shows him as the only occupant of his residence, the artifact assemblage tells possibly a different story. A ladies hatpin, hair pin, and possible garter attachment hardware indicates the presence of a woman, while a brown clay marble, found also at the site could indicate the presence of a child.

Additional research could tell us many things such as when he

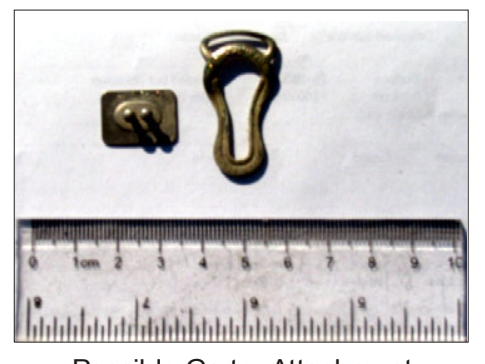

Possible Garter Attachment Hardware from the Blacker Homestead relinquished his homestead (indicating how long he occupied the site; aerial photographs taken in 1949 of the area show plow scars approximately 200 meters to the north of his homestead that indicate only 10 acres were under cultivation), if and to whom he was married, and if they had any children. We might even possibly find living descendents who could further enhance our knowledge of what life was like living on the Site in the early 1900s.

An inventory of INEEL post-1942 WWII and nuclear-era structures was also completed in FY 2004. Appendix A provides a list of inventoried structures. Although some have been determined to be exempt from the cultural properties review process, most have yet to be evaluated for their eligibility to the NRHP.

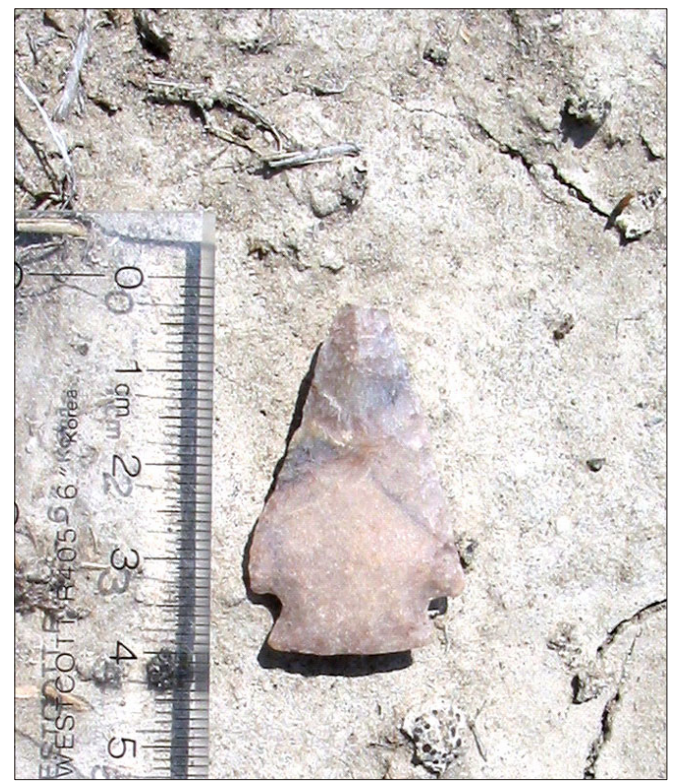

Middle Prehistoric Dart Point found during the 2004110 Survey 


\section{SITE AND PROJECT MONITORING}

A detailed description of the INEEL CRM Office monitoring program is located in Appendix L of the INEEL Cultural Resource Management Plan (DOE-ID 2004). Monitoring enables the INEEL CRM Office to document if the integrity of known resources is being compromised by natural processes, by unauthorized activities, or inadvertently by INEEL projects. By identifying impacts to cultural resources in this manner, actions to avert further deterioration can be initiated and federal stewardship responsibilities are fulfilled.

Specific cultural resources and INEEL projects are chosen for cultural resource monitoring based on feedback from DOE Idaho and INEEL CRM knowledge of INEEL Site projects and facilities. Each year, DOE Idaho

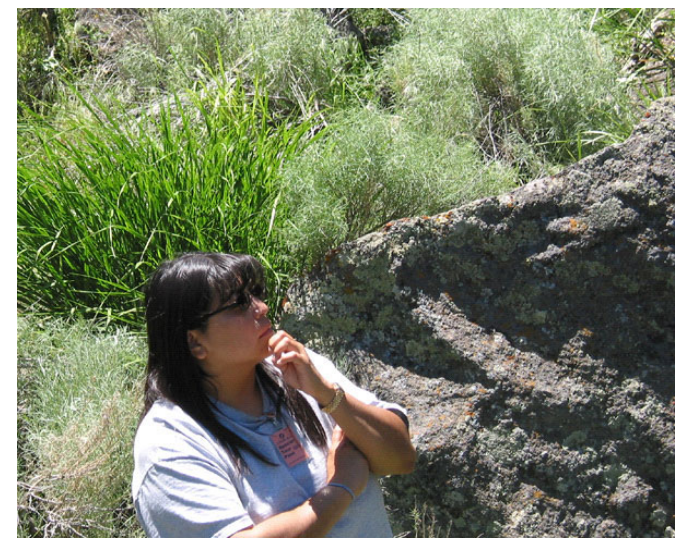

Larae Buckskin of the Shoshone Bannock Heritage Tribal Office Checks Conditions at Middle Butte Cave recommends a select number of especially sensitive localities that are then targeted for visitation. The Shoshone-Bannock Tribes are typically involved in these monitoring activities. In recent years, funding cuts have reduced the number of resources monitored and in FY 2004 only three such places were visited. Monitoring of Site projects is also limited by funding and must be responsive to the overall sensitivity of the Site and the level of project activity in any given year. For example, in the sandy aeolian soils of the Power Burst Facility complex, where Native American human remains have been found on two occasions, cultural resource monitoring of projects that involve excavation is routine and required by company procedure (MCP-3480). Accelerated cleanup and DD\&D at PBF in FY 2004 resulted in a number of CRM Office monitoring visits. This level of cultural resource oversight ensures that any additional human remains that might be encountered are handled appropriately. Cultural resource monitoring of other Site projects is typically done at the discretion of the CRM Office and again, is responsive to overall levels and areas of activity across the entire area.

In FY 2004, 15 monitoring trips were documented throughout the year (INEEL 2005). This included visits to the three especially sensitive specific cultural resource locations and involvement with six different Site projects. The three sensitive resources identified by DOE Idaho for monitoring in FY 2004 were:

- $\quad$ Middle Butte Cave

- $\quad$ Aviators' Cave

- $\quad$ 10-BT-2046, a site near the Waste Experimental Reduction Facility within the PBF complex where human remains are present.

No new impacts were observed at any of these localities. Shoshone-Bannock representatives participated in all of these visits. DOE Idaho participated in the cave visits.

The six projects subjected to cultural resource scrutiny during FY 2004 were:

- $\quad$ Miscellaneous decontamination, dismantlement, and demolition activities at PBF (5 visits)

- $\quad$ National security testing activities near PBF (1 visit) 
- $\quad$ Soil removal and remediation at the Auxiliary Reactor Area (ARA) (3 visits)

- $\quad$ Radioactive Waste Management Complex Northside Security Gate (1 visit)

- $\quad$ Monroe Gravel Pit (1 visit)

- Unmanned aerial vehicle runway (1 visit).

Company environmental procedures require project managers to contact the CRM Office in advance of ground disturbance within the fenced boundary of PBF. This is due to the occurrence of human remains in original as well as secondary contexts at two separate locations within the facility. Accelerated cleanup across the Site has resulted in an increase in the number of projects at PBF. On five occasions in FY 2004, ground disturbance was monitored for human remains. No sensitive materials were observed at any time.

A series of seventeen holes $3 \times 3 \times 3 \mathrm{ft}$ in size were excavated in the vicinity of PBF to support a new National Security testing project in FY 2004. Due to proximity to the sensitive sandy soils of PBF, these excavations were monitored for human remains and artifacts. No sensitive materials were observed at any time.

Contaminated soils surround some of the structures within the now largely demolished ARA facility. In FY 2004, these surface soils were removed down to approximately 12 inches below the surface across a large area. Archaeological sites were identified around the perimeter of this soil removal area. Monitoring for subsurface cultural materials was conducted on three occasions when project activities approached these resource locations. At no time did any of the project activities directly impact the identified resources and no sensitive materials were observed in any of the excavations.

Archaeological sites are numerous in the area immediately north of the fenced perimeter at the RWMC. Installation of a new security gate in this area in FY 2004 prompted a visit by the CRM Office staff to watch for artifacts in the limited area of excavation needed to support the project. No sensitive materials were observed at any time.

Monroe Gravel Pit, located between the Test Reactor Area and Idaho Nuclear Technology and Engineering Center is one of the most active gravel pits on the Site. In FY 2004, the western border of this gravel pit was monitored for exposure of any archaeological materials. No sensitive materials were observed in this area. An attempt was also made to re-identify the locations of archaeological sites originally recorded in the undisturbed area west of the active pit since range fires in this vicinity have created excellent surface visibility. Despite intensive pedestrian survey efforts, the three small sites originally located in this area (10 - 20 artifacts each) could not be found. Additional surveys are scheduled in this area for FY 2005 in anticipation of gravel pit expansion.

In FY 2004 a new facility was developed to support a growing unmanned aerial vehicle program. The modest runway built for this facility was placed in an area where intensive archaeological surveys and tribal communication revealed no cultural resources in the construction zone. Monitoring of construction activities showed that project personnel were aware of the limits of the area cleared for cultural resource concerns and all activities were within the bounds of the original recommendations. No sensitive cultural materials were observed at any time. 


\section{ARCHAEOLOGICAL GEOPHYSICS}

Investigations into the application of geophysical tools to archaeological research problems are a new business effort for the INEEL CRM Office. Most of the activities conducted in FY 2004 were designed to make contacts with potential customers and collaborators. Overall, this included technical reporting, presentations, informational displays, and some field work.

Technical reporting on the results of geophysical mapping at a small Middle Prehistoric $(3,500-$ 1,300 BP) hunting camp located in the middle of the INEEL Firing Range was completed in FY 2004 (Pace 2004), concluding SHPO and tribal consultation on the National Register eligibility of Site 10-BT-810. Section 8.2 provides details on the consultation. The geophysical mapping of this small site proved encouraging for future efforts in this research area, although the occurrence of metal bullet casings and other materials associated with long-term use as a live-fire range did complicate the resulting data. We are encouraged by the apparent association between ground-penetrating radar anomalies and artifact concentrations. This probably reflects differences in soil compaction and moisture content, which could be associated with intensive human activity. The radar surveys also revealed a buried stream channel in the vicinity of the site, which was not readily apparent at the current ground surface and may help to explain the presence of the site in such a seemingly featureless area.

One field project was completed in FY 2004, a modest joint effort between the INEEL, the Shoshone District of the Bureau of Land Management, and the University of Oregon. It involved electromagnetic and ground penetrating radar surveys in and around a lava tube cave (Kelvin's Cave) in advance of archaeological excavations. Imagery obtained through these surveys was valuable as a general guide for the excavations because it showed the location of a buried chamber in the cave where undisturbed cultural deposits were likely to occur as well as areas of deeper roof fall where researchers believed they would find evidence of a Pleistocene aged association between human populations and now-extinct megafauna. Plans are in place to incorporate geophysical surveys into an archaeological salvage project near the Blackfoot Reservoir in the summer of 2005. A number of research presentations and papers on this work are also planned for FY 2005.

Future plans for this new business effort call for additional reporting and presentations on the work at Kelvin's Cave, possible participation in another archaeological excavation at a rockshelter in southern Idaho or at open sites along the Snake River, and preparation of proposals for additional baseline funding to develop a library of geophysical signatures applicable to archaeological settings in cold desert regions throughout the West using a variety of real-life and simulated settings. 
10-2 


\section{PRESENT AND FUTURE ACTIVITIES}

\subsection{FY 2005 (Activities Currently Underway)}

- $\quad$ Complete an inventory of PBF/TAN non-building property types.

- $\quad$ Complete the TRA HABS/HAER report.

- Implement the stakeholder involvement plan.

- $\quad$ Compile the annual report of CRM activities.

- $\quad$ Conduct the annual meeting with SHPO, ACHP, tribes, and stakeholders.

- Integrate references to the CRMP and PA into appropriate Management Control Procedures and other procedural documents at the INEEL.

- Implement a comprehensive monitoring program to identify, track, and prevent impacts to known cultural resources throughout the INEEL. Obtain GPS locations and photographs.

- Continue development of specialized techniques and partnerships for conducting geophysical investigations of archaeological resources.

- $\quad$ Establish a plan for revisiting, re-recording, and re-evaluating cultural resources originally identified more than 10 years ago.

- Develop an EBR-I preservation plan.

- $\quad$ Develop a NAGPRA Plan of Action for the INEEL and a detailed procedure for unanticipated discoveries of human remains.

- Develop an Oral History Plan.

\subsection{Short-term Goals (1-5 Years)}

- $\quad$ Establish a comprehensive, sitewide monitoring program to identify, track, and reduce impacts to known cultural resources throughout the INEEL and for purposes of updating significance evaluations on selected properties.

- $\quad$ Expand the INEEL interpretive program.

- $\quad$ Establish roadside interpretive signage.

- $\quad$ Develop and implement a formal oral history program.

- $\quad$ Establish an ongoing research program for the INEEL through collaborative relationships with universities.

- $\quad$ Determine if the INEEL is a cultural landscape based on National Park Service criteria.

- Increase percentage of intensively surveyed INEEL lands from $8 \%$ to $15 \%$.

- $\quad$ Complete the inventory of INEEL built environment. 


\subsection{Long-term Goals}

- $\quad$ Inventory remaining nonbuilding INEEL property types.

- $\quad$ Research and write Historic American Engineering Record reports for remaining major INEEL programs.

- Write multiproperty National Register nomination package for INEEL historic properties.

- $\quad$ Identify suitable repository for post-1942 artifacts.

- $\quad$ Prepare report on archaeological and Native American resources within facility fences or within $50 \mathrm{ft}$ of existing buildings in unfenced areas.

- $\quad$ Establish creative ways to recognize INEEL employees who demonstrate good stewardship of INEEL cultural resources.

- Develop internal assessment/audit system to identify any deficiencies in the INEEL CRM Program.

- In collaboration with the Shoshone-Bannock Tribes, prepare a research design for the investigation of Native American cultural resources that may be located on the INEEL.

- $\quad$ Create a web page for the INEEL CRM Office.

- $\quad$ Complete an inventory of architectural properties at Argonne National Laboratory-West. 


\section{REFERENCES}

48 FR 190, 1983, “Archeology and Historic Preservation; Secretary of Interior's Standards and Guidelines," Federal Register, U.S. Department of the Interior, p. 44716 et seq., September 29, 1983.

AIRFA, 1978, “The American Indian Religious Freedom Act, 1978,” PL 95-341; 42 USC 1966.

AFPA, 1976, “American Folklife Preservation Act of 1976,” PL 94-201; 20 USC 2101 - 2107.

ARPA, 1979, “Archaeological Resources Protection Act, 1979," as amended, PL 96-95; 16 USC 470aa, et seq.

Bright, Robert C., and O. K. Davis, 1982, "Quaternary Paleoecology of the Idaho National Engineering Laboratory, Snake River Plain, Idaho,” American Midland Naturalist, 108(1), pp. 21-23.

Butler, B. Robert, 1968, "An Introduction to Archaeological Investigations in the Pioneer Basin Locality of Eastern Idaho," Tebiwa 11(1), pp. 1-30.

Butler, B. Robert, 1970, “A Report on the 1967-69 Archaeological Survey of the National Reactor Testing Station, Idaho,” Tebiwa 13 (1), pp. 58-75.

DOE-ID, 2004, Idaho National Engineering and Environmental Laboratory Cultural Resource Management Plan, DOE/ID-10997, Revision 0, August 2004.

DOE P 141.1, 2001, "Department of Energy Management of Cultural Resources," U.S. Department of Energy, Washington, DC, May 2, 2001.

Executive Order 13287, 2003, "Preserve America" 68 FR 10635, et seq. March 5, 2003.

Gerard, H. C., 1982, Wild Horse Jack, privately published, copyright Harry Clay Gerard.

Gianniny, Gary L., Glenn D. Thackray, Darrell S. Kaufman, Steven L. Forman, Michael J. Sherbondy, and Delda Findeisen, 2002, "Late Quaternary Highlands in the Mud Lake and Big Lost Trough Subbasins of Lake Terreton, Idaho, "Geology, Hydrogeology, and Environmental Remediation: Idaho National Engineering and Environmental Laboratory, Eastern Snake River Plain, Idaho, Special Paper 353, pp. 77-90.

INEEL, 2003, The Idaho National Environmental and Engineering Laboratory, A Historical Context and Assessment, Narrative and Inventory, INEEL/EXT-97-01021, Revision 1, prepared by the Arrowrock Group, Inc. Boise, Idaho, Contract K97-557098, September 26, 1997 (Revised November 17, 2003).

INEEL, 2005, “INEEL Cultural Resource Monitoring Report for FY 2004,” INEEL/INT-05-02623, In preparation.

Marler, Clayton F., 2004, A Paleoindian Context for the Idaho National Engineering and Environmental Laboratory, Master of Anthropology Thesis, Department of Anthropology, Idaho State University, Pocatello, Idaho. 
MCP-3480, 2004, "Environmental Instructions for Facilities, Processes, Materials and Equipment," Rev. 9, March 1, 2004.

Miller, Susanne J., 1995, Idaho National Engineering Laboratory Management Plan for Cultural Resources (Final Draft), Lockheed Idaho Technologies Company.

Nace, R. L., M. Deutsch, and P. T. Voegli, 1972, "Physical Environment of the National Reactor Testing Station, Idaho: A Summary," U.S. Geological Survey Professional Paper, 725-A, Washington, D.C.

Neitzel, Susan Pengilly, 2004, Letter to Robert A. Starck, September 20, 2004, RE: Archaeological Investigations of Site 10-BT-810 at the INEEL (TS-ETSD-04-174).

NEPA, 1969, "National Environmental Policy Act of 1969," as amended, PL 91-190; 42 USC 4321 and $4331-4335$.

NHPA, 1966, "National Historic Preservation Act of 1966," as amended, PL 89-665; 16 USC 470, et seq.

Orr, Elizabeth L. and William N. Orr, 1996, "Snake River Plain and Owyhee Uplands," Geology of the Pacific Northwest, edited by Anne C. Duffy, McGraw-Hill, New York.

Ostenaa, Dean A., Daniel R. Levish, Ralph E. Klinger, and Daniel R. H. O’Connell, 1999, "Phase 2 Paleohydrologic and Geomorphic Studies for the Assessment of Flood Risk for the Idaho National Engineering and Environmental Laboratory, Idaho," Geophysics, Paleohydrology, and Seismotectonics Group, Technical Service Center, Bureau of Reclamation, Denver, Colorado.

Pace, Brenda Ringe, 2004, Archaeological Investigations of Site 10-BT-810 at the Idaho National Engineering and Environmental Laboratory, INEEL/EXT-04-02237, Idaho Falls, Idaho, August 2004.

Plager, S. R., T. L. Johnson, A. Williams, and R. N. Holmer, 2004, "GIS Cultural Resource Predictive Model for the INEEL," Draft report, September 2004.

Ringe, B. L., 1995, Locational Analysis and Preliminary Predictive Model for Prehistoric Cultural Resources on the Idaho National Engineering Laboratory, MA thesis, Idaho State University, Department of Anthropology, Pocatello, Idaho. 
Appendix A

Building and Structures Inventoried in FY 2004 


$$
\text { A-2 }
$$


A-1. Buildings and structures inventoried in FY 2004.

National Register

Building/Structure Number and Name

Date Built Evaluation

Status

\section{STRUCTURES}

CF 701

CF 702

CF 703

CF 704

CF 707

CF 708

CF 709

CF 710

CF 711

CF 717

CF 718

CF 719

CF 720

CF 722

CF 723

CF 728

CF 731

CF 733

CF 736

CF 738

CF 739

CF 742

CF 748

CF 749

CF 753

CF 755

CF 756

CF 758

CF 761

CF 765

CF 768

CF 773

CF 776

CF 777

CF 778

CF 779

CF 780

CFA Landfill

CF 633)

Railroad Trestle

Fuel Oil Tank

CF 1704

Fuel Oil Tank

Waste Oil Tank

\#5 Fuel Oil Tank

Fence at CF 609

Fence at CF 660

Fence at CF 701

Fence at CF 716
Weather Station Farm (behind CF 690)

Microwave Tower (behind CF 606)

Concussion Wall (Navy Firing Center at

Electrical Substation for CF 689, 690

Fuel Oil Storage Tank, CFA Technical Center

Helicopter Landing Pad

CFA Loading Dock (on SPUR Track \#9)

CFA Loading Dock (on SPUR Track \#10)

Sewage Lift Station (behind CF 689)

CF Well No. 1 (Navy Well)

CF Well No. 2 (Navy Well)

Security Munitions Bunker

Fuel Oil Tank at CF 666

Jet Fuel Tank behind CR 608 replaced by

Fuel oil Tank at CF 603

Fuel Oil Tank CF 650

Fuel Oil Tank CF 650

Fuel Tank at CF 640

Diesel Oil Tank at CF 641

Tank, 50,000 gal. Steel raw water storage

25,000 gal. concrete raw water storage UST

Truck Weighing Scale

INEL Scoville Electrical Substation

Loading Dock at CF 674

Heavy Equipment Loading Dock and Ramp

Underground Storage Tank next to CF 665

Fence at CF 601 and 674

\begin{tabular}{|c|c|c|}
\hline- & Needs Assessed & Operating \\
\hline - & Needs Assessed & Operating \\
\hline 1965 & Exempted & Shutdown \\
\hline 1942 & & \\
\hline & Eligible & Operating \\
\hline - & Exempted & Operating \\
\hline - & Exempted & Operating \\
\hline - & Needs Assessed & Operating \\
\hline - & Needs Assessed & Operating \\
\hline - & Needs Assessed & Operating \\
\hline - & Exempted & Operating \\
\hline - & Needs Assessed & Inactive \\
\hline 1949 & Needs Assessed & Operating \\
\hline a. 1949 & Needs Assessed & Operating \\
\hline - & Needs Assessed & Operating \\
\hline - & Exempted & Inactive \\
\hline- & Exempted & Operating \\
\hline & Exempted & Operating \\
\hline - & Exempted & Inactive \\
\hline- & Exempted & Operating \\
\hline 1951 & Exempted & Operating \\
\hline 1951 & Exempted & Operating \\
\hline 一 & Exempted & Inactive \\
\hline - & Exempted & Operating \\
\hline - & Exempted & Operating \\
\hline - & Exempted & Operating \\
\hline - & Exempted & Inactive \\
\hline 1950 & Exempted & Shutdown \\
\hline 1950 & Needs Assessed & Shutdown \\
\hline 1951 & Exempted & Operating \\
\hline - & Needs Assessed & Operating \\
\hline - & Needs Assessed & Operating \\
\hline - & Exempted & Operating \\
\hline - & Needs Assessed & Operating \\
\hline- & Needs Assessed & Operating \\
\hline - & Needs Assessed & Operating \\
\hline - & Needs Assessed & Operating \\
\hline - & Needs Assessed & Operating \\
\hline
\end{tabular}


A-1. (Continued).

\begin{tabular}{|c|c|c|c|c|}
\hline & Building/Structure Number and Name & Date Built & $\begin{array}{c}\text { National Register } \\
\text { Evaluation }\end{array}$ & Status \\
\hline CF 781 & Propane Tank at CF 650 & - & Exempted & Operating \\
\hline CF 782 & Fire Water Tank 500,000 gallon & - & Exempted & Operating \\
\hline CF 783 & Bus Refueling Island & - & Needs Assessed & Operating \\
\hline CF 784 & Car Refueling Island & 一 & Needs Assessed & Operating \\
\hline CF 785 & Liquid Propan Tank $(18,000)$ & - & Exempted & Operating \\
\hline CF 786 & Waste Water Treatment Lagoon & 一 & Needs Assessed & Operating \\
\hline CF 787 & Waste Water Storage Lagoon & - & Needs Assessed & Operating \\
\hline CF 788 & Waste Water Polishing Lagoon & - & Needs Assessed & Operating \\
\hline CF 789 & Waste Water Disposal Pivot System & - & Needs Assessed & Operating \\
\hline CF 790 & CF 606 Flag Pole & ca. 1945 & Eligible & Operating \\
\hline CF 791 & Antifreeze Tank north of CF 696 underground & - & Exempted & Operating \\
\hline CF 792 & Oil Tank north of CF 696 underground & - & Exempted & Operating \\
\hline CF 793 & Oil Tank north of CF 696 underground & 一 & Exempted & Operating \\
\hline CF 794 & Oil Tank north of CF 696 underground & 一 & Exempted & Operating \\
\hline CF 795 & Waste Oil Tank north of CF 696 underground & 一 & Exempted & Operating \\
\hline CF 796 & Diesel Tank east of CF 696 underground & 一 & Exempted & Operating \\
\hline CF 797 & Diesel Tank east of CF 696 underground & 一 & Exempted & Operating \\
\hline CF 798 & Propane Tank east of CF 696 above ground & - & Exempted & Operating \\
\hline CF 799 & Gasoline Tank north of CF 696 & - & Exempted & Operating \\
\hline CF 1701 & Fuel Tank north of CF 668 & 一 & Exempted & Operating \\
\hline CF 1702 & Heating Oil Tank & - & Exempted & Operating \\
\hline CF 1704 & Fuel Tank & 一 & Exempted & Operating \\
\hline CF 1705 & Heating Oil Tank & - & Exempted & Operating \\
\hline CF 1706 & Fuel Tank & - & Exempted & Operating \\
\hline CF 1708 & Heating Oil Tank & - & Exempted & Operating \\
\hline CF 1710 & Vehicle Fuel Station & 2001 & Exempted & Operating \\
\hline CF 1711 & Temporary Accumulation Area & - & Needs Assessed & Operating \\
\hline CF 1713 & Propane Tank near CF 666 & 一 & Exempted & Operating \\
\hline CF 1714 & Truck Scale north of CF 629 & - & Needs Assessed & Operating \\
\hline CF 1715 & CFA Sanitary Treatment System & 一 & Exempted & Operating \\
\hline CF 1716 & LNG Tank & 一 & Exempted & Operating \\
\hline CF 1717 & Liquid Propane Tank $(12,000)$ & 一 & Exempted & Operating \\
\hline CF 1718 & Sewage Lift Station (behind CF 696) & 一 & Needs Assessed & Operating \\
\hline CF 1719 & Evacuation Siren Tower & - & Needs Assessed & Operating \\
\hline CF 1720 & Evacuation Siren Tower & - & Needs Assessed & Operating \\
\hline CPP 701 & Fuel Oil Unloading Shelter for Power House & 1951 & Needs Assessed & Operating \\
\hline CPP 701A & Fuel Oil Storage Tank & 1951 & Exempted & Operating \\
\hline CPP 701B & Fuel Oil Storage Tank & 1960 & Exempted & Operating \\
\hline CPP 702 & Fuel Oil Unloading Shelter & 1980 & Exempted & Shutdown \\
\hline CPP 702A & Fuel Oil Storage Tank & 1980 & Exempted & Shutdown \\
\hline СРP 702B & Fuel Oil Storage Tank & 1980 & Exempted & Shutdown \\
\hline
\end{tabular}


A-1. (Continued).

\begin{tabular}{|c|c|c|c|c|}
\hline & Building/Structure Number and Name & Date Built & $\begin{array}{c}\text { National Register } \\
\text { Evaluation }\end{array}$ & Status \\
\hline CPP 706 & Transformer Area at Guardhouse & 1978 & Exempted & Operating \\
\hline CPP 708 & Exhaust Stack & 1953 & Needs Assessed & Operating \\
\hline CPP 710 & Solvent Storage Building & 1953 & Needs Assessed & Shutdown \\
\hline CPP 712 & Instrument House & - & Needs Assessed & Operating \\
\hline CPP 713 & Tank Enclosure & 1953 & Exempted & Operating \\
\hline CPP 717A & STR Waste Storage Tank & 1953 & Needs Assessed & Operating \\
\hline CPP 717B & STR Waste Storage Tank & 1953 & Needs Assessed & Operating \\
\hline CPP 717C & STR Waste Storage Tank & 1953 & Needs Assessed & Operating \\
\hline CPP 717D & STR Waste Storage Tank & 1953 & Needs Assessed & Operating \\
\hline CPP 719A & Nitric Acid Storage & 1954 & Exempted & Operating \\
\hline CРP 719B & Nitric Acid Storage & 1954 & Exempted & Operating \\
\hline CPP 720A & Aluminum Nitrate Storage & 1954 & Exempted & Operating \\
\hline СРP 720B & Aluminum Nitrate Storage & 1954 & Exempted & Operating \\
\hline CPP 720C & Aluminum Nitrate Storage & 1954 & Exempted & Operating \\
\hline CPP 721 & Condenser Pit for WM-182 & 1953 & Needs Assessed & Operating \\
\hline CPP 722 & Condenser Pit for WM-183 & 1953 & Needs Assessed & Operating \\
\hline CPP 723 & Relief Valve Pit for WM-181 & 1953 & Needs Assessed & Operating \\
\hline CPP 724 & Lift Station for Waste Water Treatment Plant & 1953 & Needs Assessed & Operating \\
\hline CPP 725 & Water Storage Tank & 1951 & Exempted & Operating \\
\hline CPP 726 & Raw Water Storage Tank & 1960 & Exempted & Operating \\
\hline CPP 727 & FAST HF Acid Storage & 1983 & Exempted & Shutdown \\
\hline CPP 728 & UREP Lift Station for NWCF Plant & 1953 & Needs Assessed & Operating \\
\hline СРP 729 & Vault for Bin Set I & 1960 & Needs Assessed & Operating \\
\hline CPP 730 & Liquid Nitrogen Storage Tank & 1964 & Exempted & Operating \\
\hline СРP 731 & $\begin{array}{l}\text { Transformer Area at Process Improvement } \\
\text { Facility }\end{array}$ & 1959 & Exempted & Operating \\
\hline CPP 732 & Cooling Stack Bin Set I & 1960 & Needs Assessed & Operating \\
\hline СРP 733 & Lift Station for Eastside Sanitary Waste Line & 1953 & Needs Assessed & Operating \\
\hline СРP 735 & Transformer area at Waste Calciner & - & Exempted & Operating \\
\hline СРP 736 & Salt Storage Pit & 1984 & Exempted & Operating \\
\hline CPP 737 & Condenser Pit & 1953 & Needs Assessed & Operating \\
\hline CPP 738 & Cooling Water Pit & 1953 & Needs Assessed & Operating \\
\hline СРP 739 & Condenser Pit & 1953 & Needs Assessed & Operating \\
\hline СРP 740 & Settling Basin and Dry Well & 1953 & Exempted & Operating \\
\hline CРP 741 & WCF Solids Storage Vault & 1962 & Needs Assessed & Operating \\
\hline СРP 742 & Vault for Bin Set II & 1966 & Needs Assessed & Operating \\
\hline СРP 743 & Condenser Pit & 1953 & Needs Assessed & Operating \\
\hline СРP 744 & Vault for Bin Set II Equipment & 1965 & Needs Assessed & Operating \\
\hline СРP 746 & Vault for Bin Set III & 1971 & Needs Assessed & Operating \\
\hline СРP 747 & Vault for Bin Set III Equipment & 1971 & Needs Assessed & Operating \\
\hline СРP 748 & Lift Station for Surface Drainage & 1972 & Exempted & Operating \\
\hline СРР 749 & Peach Bottom Fuel Storage Facility & 1972 & Needs Assessed & Operating \\
\hline
\end{tabular}


A-1. (Continued).

\begin{tabular}{|c|c|c|c|c|}
\hline & Building/Structure Number and Name & Date Built & $\begin{array}{c}\text { National Register } \\
\text { Evaluation }\end{array}$ & Status \\
\hline СРР 750 & Service Waste Diversion Pump Station & 1973 & Exempted & Operating \\
\hline CPP 751 & Service Waste Monitoring Station & 1973 & Needs Assessed & Operating \\
\hline CPP 752 & Service Waste Diversion Pump Station & 1974 & Exempted & Operating \\
\hline CPP 753 & Service Waste Monitoring Station & 1974 & Exempted & Operating \\
\hline CPP 753A & Service Waste Monitoring Station & 1974 & Exempted & Operating \\
\hline СРP 754 & Service Waste Diversion Pump Station & 1975 & Exempted & Operating \\
\hline CPP 755 & Coal Storage Pad & 1980 & Needs Assessed & Shutdown \\
\hline CPP 756 & Prefilter Vault & 1976 & Exempted & Operating \\
\hline CPP 757 & FAST Sulfuric and Hydrochloric Acid Tanks & 1989 & Exempted & Operating \\
\hline СРP 758 & Leaching Cesspool & - & Exempted & Operating \\
\hline СРP 759 & Leaching Cesspool & 1977 & Exempted & Shutdown \\
\hline СРР 760 & Vault for Bin Set IV & 1977 & Needs Assessed & Operating \\
\hline СРP 761 & Vault for Bin Set IV Equipment & 1977 & Needs Assessed & Operating \\
\hline CPP 762 & Westside Condensate Pump Pit & 1978 & Exempted & Operating \\
\hline СРP 763 & Waste Diversion Tank Vault & 1969 & Needs Assessed & Operating \\
\hline СРP 764 & SFE Hold Tank Vault & 1980 & Exempted & Operating \\
\hline CPP 765 & Vault for Bin Set V & 1981 & Needs Assessed & Operating \\
\hline CPP 766 & Seepage Pit for CPP 662 & 1979 & Exempted & Operating \\
\hline СРP 767 & FAST Stack & 1985 & Needs Assessed & Operating \\
\hline СРP 768 & Sewage Lift Station for CPP 657 & 1976 & Exempted & Operating \\
\hline СРР 769 & UREP Flow Control Station & 1982 & Exempted & Operating \\
\hline CPP 770 & UREP Flow Control Station & 1982 & Exempted & Operating \\
\hline СРP 771 & UREP Flow Control Station & 1982 & Exempted & Operating \\
\hline СРP 772 & UREP Flow Control Station & 1982 & Exempted & Operating \\
\hline CPP 773 & UREP Flow Control Station & 1982 & Exempted & Operating \\
\hline СРP 774 & UREP Flow Control Station & 1982 & Exempted & Operating \\
\hline СРP 775 & Fuel Oil Pump Shed, Coal-Fired & 1983 & Exempted & Shutdown \\
\hline СРP 776 & Car Thawing Station, Coal-Fired & 1983 & Needs Assessed & Shutdown \\
\hline СРP 778 & Electrical Substation, Coal-Fired & 1983 & Exempted & Operating \\
\hline СРP 780 & Vault for Waste Tank & 1960 & Needs Assessed & Operating \\
\hline СРP 781 & Vault for Waste Tank & 1960 & Needs Assessed & Shutdown \\
\hline СРP 782 & Vault for Waste Tank & 1960 & Needs Assessed & Operating \\
\hline СРP 783 & Vault for Waste Tank & 1960 & Needs Assessed & Shutdown \\
\hline СРP 784 & Vault for Waste Tank & 1960 & Needs Assessed & Shutdown \\
\hline CPP 785 & Vault for Waste Tank & 1960 & Needs Assessed & Shutdown \\
\hline СРP 786 & Vault for Waste Tank & 1960 & Needs Assessed & Shutdown \\
\hline СРP 787 & Boiler Stack, Coal-Fired & 1983 & Needs Assessed & Shutdown \\
\hline CPP 788 & Boiler Baghouse, Coal-Fired & 1983 & Needs Assessed & Shutdown \\
\hline СРP 789 & Boiler Baghouse, Coal-Fired & 1983 & Needs Assessed & Shutdown \\
\hline СРР 791 & Vault for Bin Set V & 1984 & Needs Assessed & Operating \\
\hline СРP 792 & Ash Silo, Coal-Fired & 1983 & Needs Assessed & Shutdown \\
\hline СРР 793 & Limestone Silo, Coal-Fired & 1983 & Needs Assessed & Shutdown \\
\hline
\end{tabular}


A-1. (Continued).

\begin{tabular}{|c|c|c|c|c|}
\hline & Building/Structure Number and Name & Date Built & $\begin{array}{c}\text { National Register } \\
\text { Evaluation }\end{array}$ & Status \\
\hline СРP 794 & Coal Handling Dust Collector & 1983 & Needs Assessed & Shutdown \\
\hline CPP 795 & Vault for Bin Set VII & 1985 & Needs Assessed & Operating \\
\hline CPP 796 & Structure Replacement for CPP 734 & 1988 & Needs Assessed & Operating \\
\hline СРP 797 & Structure Replacement for CPP 709 & 1988 & Needs Assessed & Operating \\
\hline СРP 798 & HF Acid Storage & 1988 & Needs Assessed & Operating \\
\hline СРP 799 & Lift Station & 1991 & Exempted & Operating \\
\hline CPP 1711 & Deep Well & 1984 & Exempted & Operating \\
\hline CPP 1713 & Lift Station & 1986 & Exempted & Operating \\
\hline CPP 1714 & CPP 1714 to CPP 1748 are Camera Towers & - & Needs Assessed & Varies \\
\hline CPP 1749 & Emergency Pumping Stations for Waste Systems & 1988 & Exempted & Operating \\
\hline CPP 1750 & Substation & 1988 & Exempted & Operating \\
\hline CPP 1751 & Camera Tower & - & Needs Assessed & Operating \\
\hline CРP 1752 & Camera Tower & - & Needs Assessed & Shutdown \\
\hline CPP 1754 & Cesspool & 1983 & Exempted & Operating \\
\hline CPP 1755 & Cesspool & 1983 & Exempted & Shutdown \\
\hline CPP 1756 & Cesspool & 1992 & Exempted & Operating \\
\hline CPP 1757 & Cesspool & 1992 & Exempted & Operating \\
\hline CPP 1758 & Load Center \# 4 & - & Needs Assessed & Operating \\
\hline CPP 1759 & Diesel Storage Tank Basin & - & Exempted & Operating \\
\hline CPP 1760 & Kerosene Storage Tank Basin & - & Exempted & Operating \\
\hline CPP 1762 & Load Center \# 5 & - & Needs Assessed & Operating \\
\hline CPP 1764 & Load Center \# 14 & - & Needs Assessed & Operating \\
\hline CPP 1767 & Control Valve Vault & 1992 & Needs Assessed & Operating \\
\hline CРP 1769 & PoWater Storage Shed & 1992 & Needs Assessed & Operating \\
\hline CPP 1770 & Substation & 1994 & Exempted & Operating \\
\hline CPP 1771 & Substation & 1994 & Exempted & Operating \\
\hline CPP 1772 & Lift Station & - & Exempted & Operating \\
\hline CРP 1773 & Load Center \# 13 & 2000 & Needs Assessed & Operating \\
\hline CPP 1774 & TMI-2 Spent Fuel Storage Installation & 1998 & Needs Assessed & Operating \\
\hline CPP 1775 & NWCF Calciner Ventilation Stack & 1981 & Needs Assessed & Operating \\
\hline CPP 1776 & $\begin{array}{l}\text { Tunnel, starts at CPP } 606 \text { and runs under } \\
\text { complex }\end{array}$ & - & Needs Assessed & Operating \\
\hline CPP 1777 & USGS Water Quality Monitoring Station & - & Exempted & Operating \\
\hline CPP 1778 & Sewer Lagoon I,II,III,IV,V & - & Needs Assessed & Operating \\
\hline СРP 1779 & Percolation Ponds, I and II west of INTEC & 2001 & Needs Assessed & Operating \\
\hline CPP 1780 & Ash Burial Pit Coal Fire Area SE of CPP 687 & 1981 & Needs Assessed & Shutdown \\
\hline CPP 1782 & Substation \# 15 & 1998 & Needs Assessed & Operating \\
\hline CPP 1784 & Tank Enclosure & - & Needs Assessed & Operating \\
\hline CPP 1786 & Load Center \# 1 & 2001 & Needs Assessed & Operating \\
\hline EBR I 709 & Septic Tank for EBR -I & ca. 1950 & Exempted & Operating \\
\hline EBR I 710 & Deep Well Transformer Yard & ca. 1950 & Exempted & Operating \\
\hline
\end{tabular}


A-1. (Continued).

\begin{tabular}{|c|c|c|c|c|}
\hline & Building/Structure Number and Name & Date Built & $\begin{array}{c}\text { National Register } \\
\text { Evaluation }\end{array}$ & Status \\
\hline EBR I 711 & EBR I Deep Well and Pit & ca. 1950 & Exempted & Operating \\
\hline EBR I 712 & Meteorological Tower & ca. 1950 & Needs Assessed & Operating \\
\hline EBR I 713 & Seepage Pit & ca. 1950 & Exempted & Operating \\
\hline EBR I 714 & Septic Tank for EBR -I & ca. 1950 & Exempted & Operating \\
\hline EBR I 716 & Seepage Pit & ca. 1950 & Exempted & Operating \\
\hline PBF 703 & Electrical Substation (Control Area) & 1981 & Exempted & Operating \\
\hline PBF 705 & Fuel Tank & 1987 & Exempted & Operating \\
\hline PBF 706 & PBF Evaporation Tank & 1994 & Exempted & Shutdown \\
\hline PBF 707 & Electrical Substation & 1957 & Exempted & Operating \\
\hline PBF 708 & WERF Electrical Substation (was SPERT III) & 1956 & Exempted & Operating \\
\hline PBF 709 & Fuel Oil Tank & 1958 & Exempted & Shutdown \\
\hline PBF 710 & WEDF Electrical Substation (was SPERT II) & 1960 & Exempted & Operating \\
\hline PBF 711 & Fuel Oil Tank & 1988 & Exempted & Operating \\
\hline PBF 713 & MWSF Electrical Substation & 1962 & Exempted & Operating \\
\hline PBF 717 & 50,000 gallon water tank & 1962 & Exempted & Operating \\
\hline PBF 718 & Meteorological Tower & - & Needs Assessed & Operating \\
\hline PBF 719 & Electrical Substation & 1976 & Exempted & Operating \\
\hline PBF 720 & Cooling Tower (was SPERT I) & 1976 & Eligible & Shutdown \\
\hline PBF 722 & Fuel Storage Tank (SPERT I) & 1971 & Exempted & Operating \\
\hline PBF 723 & Nitrogen Tank & - & Exempted & Operating \\
\hline PBF 724 & Septic Tank (Control Area) & 1968 & Exempted & Removed \\
\hline PBF 725 & WEDF Septic Tank (SPERT II) & - & Exempted & Operating \\
\hline PBF 726 & WERF Septic Tank (SPERT III) & 1968 & Exempted & Shutdown \\
\hline PBF 727 & MWSF Septic Tank (SPERT IV) & - & Exempted & Shutdown \\
\hline PBF 728 & PBF Septic Tank & 1968 & Exempted & Operating \\
\hline PBF 729 & Fire Hose Storage (Control Area) & 1980 & Needs Assessed & Operating \\
\hline PBF 730 & Primary Coolant Water Storage Tank & 1976 & Exempted & Shutdown \\
\hline PBF 732 & Hot Waste Storage Tank & 1978 & Needs Assessed & Operating \\
\hline PBF 733 & Waste Disposal Evaporation Pond & - & Needs Assessed & Operating \\
\hline PBF 742 & Fuel Oil Tank & - & Exempted & Operating \\
\hline PBF 743 & Fuel Oil Tank & - & Exempted & Operating \\
\hline PBF 744 & Septic Tank (Control Area) & 1980 & Exempted & Operating \\
\hline PBF 745 & Seepage Pit & 1963 & Exempted & Operating \\
\hline PBF 746 & Seepage Pit & 1963 & Exempted & Operating \\
\hline PBF 749 & Diesel Fuel Tank & - & Exempted & Shutdown \\
\hline PBF 751 & Radioactive Liquid Waste Storage Tank & 1979 & Needs Assessed & Shutdown \\
\hline PBF 754 & Seepage Pit & 1980 & Exempted & Operating \\
\hline PBF 755 & WERF Exhaust Stack North & 1983 & Needs Assessed & Operating \\
\hline PBF 756 & WERF Exhaust Stack South & 1983 & Needs Assessed & Shutdown \\
\hline PBF 758 & Leaching Pond & 1962 & Needs Assessed & Operating \\
\hline PBF 759 & Seepage Pit (SPERT I) D\&D with monument & - & Needs Assessed & Operating \\
\hline
\end{tabular}


A-1. (Continued).

\begin{tabular}{|c|c|c|c|c|}
\hline & Building/Structure Number and Name & Date Built & $\begin{array}{l}\text { National Register } \\
\text { Evaluation }\end{array}$ & Status \\
\hline PBF 760 & Seepage Pit (SPERT II) & 1960 & Exempted & Operating \\
\hline PBF 761 & Spray Dryer Absorder Silo & 1990 & Needs Assessed & Operating \\
\hline PBF 763 & WERF (SPERT II) Septic Tank & 1990 & Exempted & Operating \\
\hline PBF 765 & PBF-622 Building Stack & 1990 & Needs Assessed & Shutdown \\
\hline PBF 766 & Fire Hose Storage (PBF) & 1980 & Needs Assessed & Operating \\
\hline PBF 768 & PoWater and Fire Water Tank & 1995 & Exempted & Operating \\
\hline PBF 769 & Hose House (PBF) & 1980 & Needs Assessed & Shutdown \\
\hline PBF 770 & Drain Field & 1990 & Exempted & Shutdown \\
\hline PBF 771 & Heating Oil Tank & 1994 & Exempted & Operating \\
\hline PBF 772 & Heating Oil Tank & 1994 & Exempted & Operating \\
\hline PBF 775 & Fuel Tank & - & Exempted & Shutdown \\
\hline PBF 776 & Fuel Tank & 一 & Exempted & Operating \\
\hline PBF 778 & Heating Oil Tank & - & Exempted & Operating \\
\hline PBF 779 & Heating Oil Tank & 1994 & Exempted & Operating \\
\hline PBF 780 & Drainage Basin \# 2 & 1994 & Needs Assessed & Operating \\
\hline PBF 781 & Drainage Basin \# 3 & - & Needs Assessed & \\
\hline STF 725 & Downtherm Relief Pit & ca. 1961 & Needs Assessed & \\
\hline STF 726 & Downtherm Surge Tank & ca. 1961 & Needs Assessed & Operating \\
\hline TAN 701 & Water Storage Tank & 1953 & Exempted & Shutdown \\
\hline TAN 702 & Boiler Fuel Tank (TSF area) & 1956 & Exempted & Operating \\
\hline TAN 704 & Boiler Fuel Tank (TSF area) & - & Exempted & Inactive \\
\hline TAN 705 & Turn & ca. 1955 & Eligible & Inactive \\
\hline TAN 706 & Radioactive Sample Tower (IET area) & - & Needs Assessed & Operating \\
\hline TAN 707 & Weather Tower (IET area) & - & Needs Assessed & Shutdown \\
\hline TAN 709 & Transformer Station (TSF area) & 1960 & Exempted & Operating \\
\hline TAN 710 & Septic Tank (IET) & 1956 & Exempted & Operating \\
\hline TAN 711 & Sewage Treatment Plant (TSF area) & 1954 & Needs Assessed & Operating \\
\hline TAN 714 & Weather Tower (IET area) & - & Needs Assessed & Shutdown \\
\hline TAN 715 & Unit Substation (IET area) & 1994 & Exempted & Shutdown \\
\hline TAN 716 & Exhaust Duct and Stack (CTF area) & - & Needs Assessed & Shutdown \\
\hline TAN 717 & Helicopter Pad (TSF area) & - & Needs Assessed & Shutdown \\
\hline TAN 718 & Exhaust Filter and Pad (IET area) & 1956 & Needs Assessed & Operating \\
\hline TAN 719 & Shielded Roadway to TAN 630 (CTF area) & 1956 & Needs Assessed & Operating \\
\hline TAN 720 & RPSSA Concrete Storage Casks (TSF area) & 1961 & Needs Assessed & Operating \\
\hline TAN 721 & RPSSA Heat Removal Storage Cask (TSF area) & 1961 & Needs Assessed & Shutdown \\
\hline TAN 723 & Brine Pit for Demineralizer Water System (TSF) & 1959 & Exempted & Shutdown \\
\hline TAN 724 & Boiler Fuel Tank (TSF area) & 1956 & Exempted & Shutdown \\
\hline TAN 725 & Exhaust Stack (CTF area) & 1956 & Needs Assessed & Operating \\
\hline TAN 726 & $\begin{array}{l}\text { Hot Liquid Waste Storage Tanks/Vault (CTF } \\
\text { area) }\end{array}$ & 1975 & Needs Assessed & Shutdown \\
\hline TAN 727 & Covered Stairs, East of TAN 607 (TSF area) & 1994 & Needs Assessed & Shutdown \\
\hline TAN 728 & Water Tank (WRRTF area) & - & Exempted & Shutdown \\
\hline
\end{tabular}


A-1. (Continued).

\begin{tabular}{|c|c|c|c|c|}
\hline & Building/Structure Number and Name & Date Built & $\begin{array}{c}\text { National Register } \\
\text { Evaluation }\end{array}$ & Status \\
\hline TAN 729 & Electrical Substation (WRRTF area) & - & Exempted & Shutdown \\
\hline TAN 731 & Water Storage Tank (WRRTF area) & - & Exempted & Shutdown \\
\hline TAN 732 & Propane Storage Tank (TSF area) & - & Exempted & Operating \\
\hline TAN 734 & TAN 607 Stack (TSF area) & - & Needs Assessed & Shutdown \\
\hline TAN 735 & Contaminated Waste Tank (WRRTF area) & - & Exempted & Shutdown \\
\hline TAN 737 & Septic Tank (CTF area) & 1956 & Exempted & Operating \\
\hline TAN 738 & Fuel Oil Tank (WRRTF area) & - & Exempted & Shutdown \\
\hline TAN 739 & Meteorological Tower (CTF area) & 一 & Needs Assessed & Inactive \\
\hline TAN 740 & Liquid Waste Disposal Pond & - & Needs Assessed & Shutdown \\
\hline TAN 741 & Cylinder Storage Facility & - & Needs Assessed & Shutdown \\
\hline TAN 742 & Liquid Waste Holding Tanks (TSF area & 1970 & Needs Assessed & Shutdown \\
\hline TAN 743 & TAN Cylinder Storage (TSFarea) & 1960 & Needs Assessed & Shutdown \\
\hline TAN 744 & Inlet Gas Supply Platform (CTF area) & 1960 & Needs Assessed & Shutdown \\
\hline TAN 745 & Secondary Coolant System Heating (CTF area) & 1965 & Needs Assessed & Shutdown \\
\hline TAN 746 & Condenser Shelter Structure (CTF area) & 1958 & Needs Assessed & Operating \\
\hline TAN 747 & Steam Tanks (WRRTF area) & 1960 & Needs Assessed & Operating \\
\hline TAN 748 & Water Tank (CTF area) & - & Exempted & Shutdown \\
\hline TAN 750 & Liquid Waste Disposal Pond & 1960 & Needs Assessed & Inactive \\
\hline TAN 752 & Storage Vaults & 一 & Needs Assessed & Shutdown \\
\hline TAN 754 & Propane Tank (WRRTF area) & - & Exempted & Shutdown \\
\hline TAN 755 & Boiler Fuel Tank (WRRTF area) & - & Exempted & Shutdown \\
\hline TAN 756 & Slop Tank (CTF area) & 1990 & Exempted & Shutdown \\
\hline TAN 757 & Propane Tank (WRRTF area) & - & Exempted & Shutdown \\
\hline TAN 760 & Fire Hose House (WRRTF area) & 1958 & Needs Assessed & Shutdown \\
\hline TAN 761 & Fire Hose House (WRRTF area) & 1958 & Needs Assessed & Shutdown \\
\hline TAN 762A & Sewage Lagoon (WRRTF area) & - & Needs Assessed & Shutdown \\
\hline TAN 763 & Evaporation Pond (WRRTF area) & - & Needs Assessed & Shutdown \\
\hline TAN 764 & Contaminated Waste Tank (CTF area) & 1991 & Exempted & Shutdown \\
\hline TAN 765 & Slop Tank (CTF area) & 1970 & Exempted & Shutdown \\
\hline TAN 766 & Diesel Fuel Oil Tank (CTF area) & 1960 & Exempted & Shutdown \\
\hline TAN 767A & Boiler Fuel Tank (CTF area) & 1959 & Exempted & Shutdown \\
\hline TAN 768 & Electrical Substation (CTF area) & - & Exempted & Operating \\
\hline TAN 769 & Electrical Substation (CTF area) & 1994 & Exempted & Shutdown \\
\hline TAN 771 & Sulfuric Acid Tank (CTF area) & 1959 & Exempted & Operating \\
\hline TAN 772 & Liquid Nitrogen Tank (CTF area) & 1959 & Exempted & Shutdown \\
\hline TAN 774 & Concrete Slab (CTF area) & 1959 & Needs Assessed & Shutdown \\
\hline TAN 776 & Transformer Station (TSF area) & 1969 & Exempted & Operating \\
\hline TAN 778 & Water Blowdown Tank (TSF area) & - & Needs Assessed & Shutdown \\
\hline TAN 779 & Diesel Fuel Tank TAN 603 (TSF area) & 1990 & Exempted & Operating \\
\hline TAN 780 & Tank, TAN 603 (TSF area) & 1970 & Exempted & Operating \\
\hline TAN 781 & Drainage Pond (TSF area) & - & Needs Assessed & Operating \\
\hline TAN 783 & Gasoline Tank (TSF area) & - & Exempted & Operating \\
\hline
\end{tabular}


A-1. (Continued).

\begin{tabular}{|c|c|c|c|c|}
\hline & Building/Structure Number and Name & Date Built & $\begin{array}{c}\text { National Register } \\
\text { Evaluation }\end{array}$ & Status \\
\hline TAN 788 & Diesel Fuel Tank (WRRTF area) & 1990 & Exempted & Operating \\
\hline TAN 789 & Diesel Fuel Tank (WRRTF area) & 1990 & Exempted & Operating \\
\hline TAN 790 & Abnormal Waste Storage Pad (TSF area) & 1986 & Needs Assessed & Operating \\
\hline TAN 791 & Spent Fuel Storage Pad (TSF area) & - & Needs Assessed & Operating \\
\hline TAN 793 & Bus Fuel Pump (TSF area) & - & Exempted & Operating \\
\hline TAN 794 & Diesel Generator Fuel Tank (TSF area) & 1993 & Exempted & Operating \\
\hline TAN 796 & Transformer Station (TSF area) & - & Exempted & Operating \\
\hline TAN 797 & Diesel Oil Storage Tank (TSF area) & 1993 & Exempted & Operating \\
\hline TAN 1701 & Foam Solution Storage Tank (CTF area) & 1994 & Exempted & Shutdown \\
\hline TAN 1702 & Diesel Fuel Tank & 1990 & Exempted & Shutdown \\
\hline TAN 1705 & Lube Oil Tank & 1991 & Exempted & Shutdown \\
\hline TAN 1706 & Fuel Oil Tank & 1990 & Exempted & Shutdown \\
\hline TAN 1707 & Acid Pid & - & Exempted & Shutdown \\
\hline TAN 1708 & Pneumatic Tank for Water System & - & Exempted & Shutdown \\
\hline TAN 1714 & Foam Stabilizer Tank & 1991 & Exempted & Operating \\
\hline TAN 1715 & Gas Storage Tank & 1992 & Exempted & Operating \\
\hline TAN 1717 & Surface Runoff Well \#1 & - & Exempted & Operating \\
\hline TAN 1718 & Surface Runoff Well \#4 & - & Exempted & Operating \\
\hline TAN 1721 & Gas Tank & - & Exempted & Shutdown \\
\hline TAN 1724 & IET Exhaust Stack & ca. 1955 & Needs Assessed & Operating \\
\hline TAN 1725 & IET Exhaust Filter Room & ca. 1955 & Needs Assessed & Operating \\
\hline TAN 1726 & Disposal Well & - & Exempted & Operating \\
\hline TAN 1728 & Disposal Well & - & Exempted & Inactive \\
\hline TAN 1729 & Cask Dry Storage Pad & - & Needs Assessed & Operating \\
\hline TAN 1730 & Rad-Haz Mixed Waste Water Storage Tank & - & Exempted & Operating \\
\hline TAN 1731 & SMC Substation & - & Exempted & Operating \\
\hline TAN 1732 & Deep Well Chlorination Unit & - & Needs Assessed & Operating \\
\hline TAN 1733 & Deep Well Chlorination Unit & 2000 & Needs Assessed & Operating \\
\hline TAN 1739 & Heating Oil Tank & - & Exempted & Operating \\
\hline TAN 1740 & Heating Oil Tank & - & Exempted & Operating \\
\hline TAN 1741 & Heating Oil Tank & 1986 & Exempted & Shutdown \\
\hline TAN 1742 & Heating Oil Tank & 1986 & Exempted & Shutdown \\
\hline TAN 1743 & Sewage Lift Station & - & Needs Assessed & Operating \\
\hline TAN 1744 & Process Waste Water Lift Station & - & Needs Assessed & Shutdown \\
\hline TAN 1745 & Sewer Lagoons I,II,III, (CTF area) & - & Needs Assessed & Operating \\
\hline TAN 1746 & Explosive Bunkers (6) & - & Needs Assessed & Operating \\
\hline TAN 1747 & Incinerator N.E. or TAN 675 (CTF area) & - & Needs Assessed & Operating \\
\hline TAN 1748 & Ground Water Treatment Facility (TSF area) & - & Needs Assessed & Operating \\
\hline TAN 1749 & Water Tank & 2000 & Exempted & Operating \\
\hline TAN 1750 & SMC Tank Monument Pad & 2000 & Needs Assessed & Operating \\
\hline TAN 1751 & SMC Utility Vault & 2001 & Needs Assessed & Operating \\
\hline TAN $1752 \mathrm{~A}$ & Nitrogen Tank & 2002 & Exempted & Operating \\
\hline
\end{tabular}


A-1. (Continued).

\begin{tabular}{|c|c|c|c|c|}
\hline & Building/Structure Number and Name & Date Built & $\begin{array}{c}\text { National Register } \\
\text { Evaluation }\end{array}$ & Status \\
\hline TAN 1752B & Nitrogen Tank & 2002 & Exempted & Operating \\
\hline TAN $1752 \mathrm{C}$ & Nitrogen Tank & 2002 & Exempted & Operating \\
\hline TAN 1753 & Hydrogen Tank & 2002 & Exempted & Operating \\
\hline TAN 1754A & Propane Tank & 2002 & Exempted & Under construct. \\
\hline \multirow[t]{2}{*}{ TAN 1754B } & Propane Tank & 2002 & Exempted & \\
\hline & & & & Operating \\
\hline TRA 701 & Chemical Leaching Pond & 1962 & Needs Assessed & Operating \\
\hline TRA 702 & Cold Waste Pond & 1982 & Needs Assessed & Shutdown \\
\hline TRA 703 & Cold Waste Sump Pit & 1952 & Needs Assessed & Shutdown \\
\hline TRA 704 & Primary Filter Pit & 1957 & Needs Assessed & Shutdown \\
\hline TRA 706 & Delay Tanks & 1957 & Exempted & Shutdown \\
\hline TRA 707 & Fuel Pum Island and Pad & - & Needs Assessed & Operating \\
\hline TRA 708A & Water Storage Tank & 1952 & Exempted & Operating \\
\hline TRA 708B & Water Storage Tank & 1952 & Exempted & Operating \\
\hline TRA 708C & Water Storage Tank & 1985 & Exempted & Operating \\
\hline TRA 709 & Air Intake Shaft (MTR) & 1952 & Needs Assessed & Operating \\
\hline TRA 710 & MTR Stack & 1952 & Needs Assessed & Shutdown \\
\hline TRA 711 & ATR Pumphouse Transformer Pad & 1963 & Needs Assessed & Shutdown \\
\hline TRA 712 & Retention Basin (underground) & 1952 & Exempted & Shutdown \\
\hline TRA 713A & Hot Waste Storage Tank (underground) & 1989 & Exempted & Shutdown \\
\hline TRA 713B & Hot Waste Storage Tank (underground) & 1989 & Exempted & Shutdown \\
\hline TRA 713C & Hot Waste Storage Tank (underground) & 1989 & Exempted & Shutdown \\
\hline TRA 713D & Hot Waste Storage Tank (underground) & 1989 & Exempted & Operating \\
\hline TRA 714 & Valve Box & 1952 & Needs Assessed & Operating \\
\hline TRA 715 & TRA Evaporation Pond & 1988 & Needs Assessed & Operating \\
\hline TRA 716 & Warm Waste Transfer Sump & 1988 & Needs Assessed & Operating \\
\hline TRA 718 & Overhead Raw Water Storage Tank & 1961 & Exempted & Operating \\
\hline TRA 719A & Water Storage Tank & 1961 & Exempted & Operating \\
\hline TRA 719B & Water Storage Tank & 1961 & Exempted & Operating \\
\hline TRA 719C & Water Storage Tank & 1961 & Exempted & Unkown \\
\hline TRA 721 & Fence at WRPTF & - & Needs Assessed & Operating \\
\hline TRA 722 & TRA Utility Corridor & - & Needs Assessed & Operating \\
\hline TRA 723 & Sewer Manhole & 1996 & Exempted & Operating \\
\hline TRA 724 & Lift Station & 1996 & Needs Assessed & Operating \\
\hline TRA 725 & Lift Pump & 1996 & Needs Assessed & Operating \\
\hline TRA 726 & Lift Pump & 1996 & Needs Assessed & Shutdown \\
\hline TRA 727A & Fuel Oil Storage Tank Out of Service & 1952 & Exempted & Shutdown \\
\hline TRA 727B & Fuel Oil Storage Tank Out of Service & 1952 & Exempted & Operating \\
\hline TRA 727C & Diesel Oil Storage Tank & 1952 & Exempted & Shutdown \\
\hline TRA 727D & Diesel Oil Storage Tank & - & Exempted & Shutdown \\
\hline TRA 730A & Catch Tank & 1985 & Exempted & Shutdown \\
\hline TRA 730B & Catch Tank & 1985 & Exempted & Shutdown \\
\hline
\end{tabular}


A-1. (Continued).

\begin{tabular}{|c|c|c|c|c|}
\hline & Building/Structure Number and Name & Date Built & $\begin{array}{c}\text { National Register } \\
\text { Evaluation }\end{array}$ & Status \\
\hline TRA 730C & Catch Tank & 1985 & Exempted & Shutdown \\
\hline TRA 730D & Catch Tank & 1985 & Exempted & Shutdown \\
\hline TRA 731A & Brine Storage Pit & 1952 & Needs Assessed & Shutdown \\
\hline TRA 731B & Caustic Storage Tank & 1952 & Needs Assessed & Shutdown \\
\hline TRA 731C & Caustic Storage Tank & 1952 & Needs Assessed & Shutdown \\
\hline TRA 731D & Acid Storage & 1952 & Needs Assessed & Shutdown \\
\hline TRA 731E & Acid Storage & 1952 & Needs Assessed & Operating \\
\hline TRA 732 & Sewage Treatment Plant & 1952 & Needs Assessed & Operating \\
\hline TRA 733 & Transfer Structure between Lagoon \#1 and \#2 & 1996 & Needs Assessed & Operating \\
\hline TRA 734 & Transfer Structure east of lagoon \#2 & 1996 & Needs Assessed & Operating \\
\hline TRA 736 & Lagoon \#2 & 1996 & Needs Assessed & Operating \\
\hline TRA 751 & ETR Cooling Tower Basin & - & Needs Assessed & Shutdown \\
\hline TRA 752 & ETR Transformer Yard & 1955 & Needs Assessed & Operating \\
\hline TRA 753 & ETR Waste Gas Stack & 1954 & Needs Assessed & Shutdown \\
\hline TRA 754 & Demineralized Water Storage Tank & 1954 & Exempted & Operating \\
\hline TRA 758 & Leaching Pond & - & Exempted & Shutdown \\
\hline TRA 759 & Vehicle Refueling Station & 1952 & Needs Assessed & Operating \\
\hline TRA 760 & Effluent Water Monitoring Station & - & Exempted & Operating \\
\hline TRA 762 & Firewater Loop Valve Box & 1961 & Exempted & Shutdown \\
\hline TRA 763B & Storage Tank & 1952 & Exempted & Operating \\
\hline TRA 763C & Storage Tank & 1952 & Exempted & Operating \\
\hline TRA 764 & Cold Waste Sampling Pit & 1962 & Needs Assessed & Operating \\
\hline TRA 770 & Air Waste Gas Stack & 1964 & Needs Assessed & Operating \\
\hline TRA 771 & ATR Cooling Tower & 1964 & Needs Assessed & Operating \\
\hline TRA 772 & Resin Collection Vault & 1996 & Needs Assessed & Operating \\
\hline TRA 773 & Valve Box & 1996 & Needs Assessed & Operating \\
\hline TRA 774 & Transformer Yard & 1964 & Exempted & Operating \\
\hline TRA 775 & Diesel Oil Storage Tank & 1964 & Exempted & Operating \\
\hline TRA 776 & ATR Diesel Oil Day Tank & 1964 & Exempted & Operating \\
\hline TRA 777A & Propane Tank & 1993 & Exempted & Operating \\
\hline TRA 777B & Gasoline Tank & 1991 & Exempted & Operating \\
\hline TRA 777C & Diesel Tank & 1991 & Exempted & Operating \\
\hline TRA 778 & Fuel Pump Island & 1991 & Needs Assessed & Operating \\
\hline TRA 779 & Decon Pad & 1989 & Needs Assessed & Operating \\
\hline TRA 780 & Temporary Accumulation Area Concrete Pad & 1995 & Needs Assessed & \\
\hline TRA 781 & Firewater Storage Tank & 2000 & Exempted & Operating \\
\hline TRA 783 & MTR Process Water Res. & 1951 & & \\
\hline TRA 784 & Liquid Nitrogen Tank & 2000 & Exempted & $\begin{array}{l}\text { Operating } \\
\text { Operating }\end{array}$ \\
\hline WMF 700 & Subsurface Disposal Area & 1954 & Needs Assessed & Shutdown \\
\hline WMF 701 & Fence, SDA & - & Needs Assessed & Operating \\
\hline WMF 702 & Liquid Chemical Disposal Area & 1983 & Needs Assessed & Operating \\
\hline
\end{tabular}


A-1. (Continued).

\begin{tabular}{|c|c|c|c|c|}
\hline & Building/Structure Number and Name & Date Built & $\begin{array}{c}\text { National Register } \\
\text { Evaluation }\end{array}$ & Status \\
\hline WMF 703 & Propane Tank & 1970 & Exempted & Operating \\
\hline WMF 704 & Timber Bridge (over drainage ditch) & 1954 & Needs Assessed & Operating \\
\hline WMF 706 & Fence, TSA & - & Needs Assessed & Operating \\
\hline WMF 707 & Evaporator Pond & - & Needs Assessed & Operating \\
\hline WMF 708 & Sump Pit & 1972 & Needs Assessed & Operating \\
\hline WMF 712 & Inner Containment Building & 1983 & Needs Assessed & Operating \\
\hline WMF 714 & Intermediate Level Transuranic Storage Facility & 1977 & Needs Assessed & Operating \\
\hline WMF 715 & Air Support Weather Shield & - & Needs Assessed & Operating \\
\hline WMF 720 & Intermediate Level Transuranic Storage Facility & 1984 & Needs Assessed & Operating \\
\hline WMF 721 & Gravity Drain Structure & - & Needs Assessed & Operating \\
\hline WMF 726 & Adams Boulevard Bridge & - & Needs Assessed & Removed \\
\hline WMF 727 & Fire Water Tank & 1994 & Exempted & Operating \\
\hline WMF 729 & VVE Gas analysis Trailer & - & Exempted & Operating \\
\hline WMF 730 & Concrete Lined Disposal Vaults & 1993 & Needs Assessed & Operating \\
\hline WMF 731 & RWMC Sewage Lagoon & - & Needs Assessed & Operating \\
\hline WMF 732 & Propane Tank & 1997 & Exempted & Operating \\
\hline WMF 733 & Drum Inspection Station inside WMF 612 & 一 & Needs Assessed & Operating \\
\hline WMF 734 & TSA Standby Generator Enclosure & 一 & Needs Assessed & Operating \\
\hline WMF 735 & Diesel Fuel Tank & - & Exempted & Operating \\
\hline WMF 736 & Cold Test Pit & - & Needs Assessed & Operating \\
\hline WMF 737 & Gasoline Tank & - & Exempted & Operating \\
\hline WMF 738 & Propane Tank & - & Exempted & Operating \\
\hline WMF 739 & Well House & 1979 & Exempted & Operating \\
\hline WMF 740 & Well House & 1979 & Exempted & Operating \\
\hline WMF 741 & Well House & 1979 & Exempted & \\
\hline AEF 703 & Seepage Pit & - & Not Assessed & \\
\hline AEF 704 & Diesel Oil Storage Tank & - & Not Assessed & Operating \\
\hline B16 704 & Fire Department Training Tower at Station \#2 & 1958 & Not Assessed & Operating \\
\hline B16 705 & Water Tank, Fire Station \#2 & - & Not Assessed & Operating \\
\hline B16 707 & Loading Dock on CPP-NRF Railroad & - & Needs Assessed & Operating \\
\hline B16 708 & Evaporation Pond, Fire Station $\# 2$ & 1958 & Needs Assessed & Operating \\
\hline B17 701 & $\begin{array}{l}\text { Bridge over Big Lost River on Lincoln } \\
\text { Boulevard }\end{array}$ & - & Needs Assessed & Operating \\
\hline B17 702 & Army Re-entry Facility Site Storage Bunker & - & Eligible & Operating \\
\hline B18 701 & Bridge near EBR-II on Buchanan Blvd & - & Needs Assessed & Operating \\
\hline B21 702 & Culverts & - & Needs Assessed & Operating \\
\hline B21 703 & Gun Range Target Pits & - & Needs Assessed & Operating \\
\hline B21 704 & Gun Range Observation Tower & - & Needs Assessed & Operating \\
\hline B21 705 & Personnel Bunkers & - & Needs Assessed & Operating \\
\hline B21 706 & Munitions Bunker & - & Needs Assessed & Operating \\
\hline B21 707 & Munitions Bunker & - & Needs Assessed & Operating \\
\hline B21 708 & Munitions Bunker & - & Needs Assessed & Operating \\
\hline
\end{tabular}


A-1. (Continued).

\begin{tabular}{llcll}
\hline & & & National Register & \\
& \multicolumn{1}{c}{ Building/Structure Number and Name } & Date Built & Evaluation & Status \\
\hline B21 710 & Long Range Rifle Range \#1 & - & Needs Assessed & Operating \\
B21 711 & Range 2/Shotgun/Steel Range & - & Needs Assessed & Operating \\
B21 712 & Qualifications Range \# 3 & - & Needs Assessed & Operating \\
B21 713 & Known Distance Sniper Range & - & Needs Assessed & Operating \\
B21 714 & Tactical Range \# 6 & - & Needs Assessed & Operating \\
B21 715 & Indoor Pistol and Rifle Range & - & Needs Assessed & Operating \\
B21 716 & Distribution Substation & - & Exempted & Operating \\
B21 717 & Bridge on Lincoln south of Monroe & - & Needs Assessed & Operating \\
B21 718 & INTEC Percolation Pond & 2002 & Needs Assessed & Operating \\
B21 719 & INTEC Percolation Pond & 2002 & Needs Assessed & Operating \\
B21 720 & INTEC Perc Ponds Valve Vault & 2002 & Needs Assessed & Operating \\
& & & & \\
TAN 801 & DobJECTS & & & \\
TAN 802 & Dolly Trackage from TSF/A\&M to IET & - & Needs Assessed & Shutdown \\
TAN 803 & Dolly Trackage from TSF/A\&M to LOFT & - & Needs Assessed & Shutdown \\
TAN 804 & Railroad dolly for SNAP/TRAN-2 & - & Needs Assessed & Shutdown \\
TAN 805 & Railroad dolly for SNAP/TRAN-2 & - & Needs Assessed & Shutdown \\
TAN 806 & MTA railroad dolly for LOFT project & - & Needs Assessed & Shutdown \\
TAN 807 & Sheilded locamotive & - & Eligible & Shutdown \\
TAN 808 & GE/ANP P 102 railroad dolly & - & Needs Assessed & Shutdown \\
TAN 809 & PM2A railroad dolly & - & Needs Assessed & Shutdown \\
\hline
\end{tabular}

